\title{
Casos escogidos de Derecho antitrust europeo
}

\author{
Bajo la coordinación de \\ Alfonso-Luis Calvo Caravaca \\ Catedrático de Derecho Internacional Privado \\ Universidad Carlos III de Madrid \\ $\mathrm{y}$ \\ María Pilar Canedo Arrillaga \\ Profesora doctora de Derecho Internacional Privado \\ Universidad de Deusto
}

\section{Introducción}

El 2 de diciembre de 2005, la Universidad de Deusto celebró un Seminario sobre Derecho Europeo de la Competencia dirigido por la Profesora Dra. María Pilar Canedo Arrillaga, que contó con un entusiasta y disciplinado equipo de colaboradores. Fue una oportunidad magnífica para ofrecer a los asistentes una muestra de las posibilidades docentes de la Universidad en sectores como éste, que atraen la atención de los investigadores y que poseen una indudable proyección profesional.

Fue, además, un encuentro entre especialistas, del que salieron algunos de los trabajos que publica este volumen de los Estudios de Deusto. Algunos de los participantes comentamos privadamente la utilidad de las crónicas de Derecho europeo de la competencia que recogen las Revistas especializadas y lamentamos que, hasta ahora, no hayamos sido capaces de poner en común nuestras notas con comentarios sobre las decisiones de la Comisión o del Tribunal de Justicia relativas a este sector.

Fue así como surgió la idea que ha germinado en estos «Casos escogidos» que se presentan al lector. No es una crónica al uso. Hemos preferido la selección de los casos y el rigor de los comentarios antes que una visión panorámica y superficial, como tantas al uso. Hemos preferido que sea una sección anual, para disponer del tiempo necesario para sedimentar los casos que hay que conocer. Hemos preferido, en tercer lugar, ceñirnos al Derecho antitrust europeo, entendido como el sector privado del Derecho europeo de la competencia que se ocupa de las conductas de las empresas (ententes, abusos de posición dominante y concentraciones de empresas) que puede hacer peligrar la competencia efectiva en el interior del Mercado común europeo. No se ocupa, por tanto, esta sección del sector público del Derecho de la competencia europeo, que se afana por regular los com- 
portamientos imputables a los Estados miembros de la UE (grosso modo, empresas públicas, monopolios comerciales de Estado y ayudas de Estado) que son susceptibles de lesionar sustancialmente la competencia efectiva en el Mercado común, sector que se encuentra sometido actualmente a un profundo proceso de revisión legislativa en el seno de la UE.

Participan en esta sección profesores de la Universidad Carlos III de Madrid (Alfonso-Luis Calvo Caravaca y Juliana Rodríguez Rodrigo), Universidad de Deusto (María Pilar Canedo Arrillaga y Marta Casado Abarquero), Universidad de Extremadura (Manuela Eslava Rodríguez y Mercedes Sabido Rodríguez), Universidad Pública de Navarra (Natividad Goñi Urriza) y Universidad de Valladolid (Carmen Herrero Suárez).

Alfonso-Luis Calvo Caravaca y María Pilar Canedo Arrillaga

\section{Ententes}

Caso N. ${ }^{\circ}$ 1. Ententes: Dec.Com. 7 abril 2004, Société Air France/Alitalia Linee Aeree Italiane SpA, DO L 362 de 9 diciembre 2004

Nota

1. La Sociedad francesa Air France y la sociedad italiana Alitalia solicitaron a la Comisión, con arreglo al Reglamento 3975/87 del Consejo de 14 de diciembre de 1987, por el que se establecen las normas de desarrollo de las reglas de competencia para empresas del sector del transporte aéreo (DO L 374 de 31 diciembre 1987), la declaración negativa o, en su caso, la exención de un acuerdo celebrado entre las mismas por el que, a largo plazo, se pretende la constitución de una alianza estratégica. Los principales objetivos del acuerdo notificado se concretan en la creación de un sistema europeo multicentros basado en los centros de operaciones que poseen las partes en París, Roma y Milán, para interconectar sus redes mundiales; la coordinación de las operaciones de servicios a los pasajeros de ambas partes; así como la cooperación en otras áreas. Atendiendo a estos objetivos, la cooperación propuesta abarca actividades relativas al transporte aéreo regular de pasajeros, al transporte aéreo de mercancías y los servicios de asistencia en tierra.

2. La Comisión, tras analizar el acuerdo notificado a la luz del art. 81 TCE, resuelve declarando la exención, de conformidad con el párrafo tercero del art. 81 TCE, respecto del acuerdo relativo al transporte aéreo regular de pasajeros durante el período comprendido entre el 12 de noviembre de 2001 (fecha en la que se efectuó la notificación) y el 11 de noviembre de 2007. Esta declaración de exención está condicionada al cumplimiento de los compromisos, anejos a la decisión, elaborados por las empresas solicitantes. Junto 
a la propia creación de una alianza estratégica, de la Decisión adoptada por la Comisión debe destacarse el análisis «detallado» que efectúa a la luz del art. 81 TCE y el hecho de condicionar la declaración de exención al cumplimiento de determinados compromisos.

3. La creación de una alianza estratégica supone la celebración de acuerdos de cooperación entre empresas que se encuentran en el mismo nivel de producción, a través de los cuales se establecen varios vínculos. Se trata, por tanto de un acuerdo entre empresas competidoras que, en la actualidad, se configuran como instrumento o medio de competir en el mercado integrado a escala mundial y que suele ser frecuente en sectores del comercio que han sido recientemente liberalizados. A partir de estas consideraciones, su análisis desde la perspectiva de las normas que consagran la libre competencia suscita algunas cuestiones. De un lado, su exclusión del régimen previsto para las concentraciones de empresas se justifica en la propia finalidad de la alianza estratégica notificada por Air France y Alitalia. En ella no se proponen cambios estructurales ni tampoco la creación de una entidad independiente, limitándose a la creación de vínculos contractuales. De otra parte, aun tratándose de un acuerdo de cooperación horizontal el supuesto no es subsumible en el ámbito de aplicación de las normas que regulan este tipo de acuerdos no sólo por la complejidad que entraña la propia alianza estratégica y que requiere un análisis conjunto de los distintos acuerdos que la integran, sino también porque en el ámbito material afectado, el transporte aéreo, existen normas específicas a través de las cuales se lleva a cabo la ordenación jurídica del sector desde la perspectiva de las normas de la competencia (Vid Cdo. 12 y 13 de las Directrices sobre la aplicación del art. 81 TCE a los acuerdos de cooperación horizontal DO C 2001).

4. En el marco del art. 81 TCE la Comisión debe analizar si la alianza estratégica propuesta por Air France y Alitalia constituye o no una entente en el sentido del párrafo primero del precepto citado y, respondiendo afirmativamente a esta primera cuestión, debe valorar la concurrencia de las condiciones exigidas en el párrafo tercero del mismo precepto $\mathrm{y}$, de este modo, determinar si los beneficios que pueda producir el acuerdo notificado superan los efectos restrictivos de la competencia que del mismo se derivan y, en consecuencia, puede ser declarado exento. Partiendo de la delimitación del mercado de referencia y la posición que ocupan las partes en el mismo, el análisis efectuado por la Comisión hasta adoptar la presente Decisión ha sido muy detallado.

5. Establecer el mercado de relevancia y la posición que ocupan las partes en él, constituye, en el ámbito del art. 81 TCE un dato esencial para decidir sobre la afectación a la competencia, actual o potencial, entre las 
empresas participantes o con otras empresas así como, en el marco del párrafo tercero del precepto citado, para determinar si el acuerdo deja subsistir el mínimo de competencia exigido. Siguiendo los criterios anteriormente adoptados por la Comisión para determinar el mercado de referencia en el sector del transporte aéreo, en la presente Decisión vuelve a utilizar el concepto de binomio país de origen/país de destino (O+D). Cada combinación $\mathrm{O}+\mathrm{D}$ es, desde el punto de vista del cliente, un mercado separado. Sólo a partir de un análisis adecuado del cada mercado podrá concluirse, en primer término, si el acuerdo notificado tiene efectos anticompetitivos probables en el mismo y, en segundo lugar, siendo afirmativa la respuesta, valorar, en segundo lugar, si tales efectos restrictivos pueden ser superados por los beneficios que al mercado reporta el acuerdo.

6. La Comisión, tras analizar, de este modo, el acuerdo notificado, manifestó serias dudas respecto a la cooperación intensa en el transporte aéreo regular de pasajeros que las partes proponen entre Francia e Italia. Atendiendo al contexto real del mercado de referencia, se considera que este acuerdo puede restringir la competencia en los mercados de referencia. Antes del acuerdo, en los siete binomios $\mathrm{O}+\mathrm{D}$, las partes competían entre sí, siendo los dos operadores principales con cuotas muy altas de mercado. A la posición consolidada de las partes en el mercado de referencia se añaden circunstancias que coadyuvan a la ampliación de este poder y pueden producir, tras el acuerdo, efectos restrictivos de la competencia. Entre estas circunstancias se encuentran la escasez de franjas horarias, la alta cuota de clientes de las partes y el elevado número de frecuencias de vuelo de las partes. Estas barreras a la entrada de potenciales competidores distorsionan la competencia. El acuerdo, por tanto, puede producir efectos restrictivos de la competencia $\mathrm{y}$, como tal, está prohibido con base en el art. 81.1 TCE.

7. Siendo subsumible en el ámbito de aplicación del precepto citado, la Comisión procede a valorar, en consonancia con lo solicitado por las empresas participantes en el acuerdo, la posibilidad de que el mismo pudiera ser declarado exento. Posibilidad que se encuentra condicionada a la concurrencia de las condiciones exigidas por el párrafo tercero del art. 81 TCE.

8. No se duda de los beneficios que la creación de este tipo de acuerdos reporta para el fomento del progreso técnico y científico. La alianza contribuye a mejorar la producción y distribución del servicio del transporte, a fomentar el progreso técnico y económico y puede generar beneficios a través de la creación de una red mayor a nivel mundial. Ahora 
bien, las dudas de la Comisión, a la que se añaden las observaciones efectuadas por terceros, se suscitan en relación con la necesaria participación equitativa de los usuarios en los beneficios obtenidos. Se ofrecerán a los clientes mejores servicios, pero el consumidor únicamente podrá participar equitativamente de los beneficios, mediante la reducción de precios o el incremento en la calidad de los servicios, si las partes continúan sujetas a una presión competitiva en aquellos mercados en los que la alianza restringe la competencia. En su opinión, los acuerdos restringen la competencia en el mercado del transporte aéreo regular de pasajeros y sólo manteniendo una presión competitiva en los mercados el consumidor podrá participar equitativamente en los beneficios resultantes de la cooperación. Sin embargo, en los términos en los que se redactó el acuerdo notificado, atendiendo al contexto del mercado de referencia en el que el mismo se desarrolla, debe advertirse que las partes fortalecen su posición de mercado y se mantienen barreras a la entrada de posibles competidores. No se mantiene, por tanto, una presión competitiva en el mercado de referencia y, consecuentemente, no es posible una participación equitativa de los consumidores en los beneficios que reporta el acuerdo. Sólo modificando ciertos aspectos del acuerdo que permitan superar tales deficiencias, garantizando un mínimo de competencia, podría lograrse que el efecto positivo que reporta el acuerdo supere la restricción de la competencia que el mismo produce. Se debe, en definitiva, eliminar las barreras de entrada a posibles competidores.

9. Estas observaciones llevan a las partes a elaborar una serie de compromisos, igualmente publicados y a los que se efectuaron observaciones hasta llegar a adoptar, tras importantes negociaciones, la forma definitiva. Básicamente estos compromisos, que tienen por objeto eliminar las barreras a la entrada de nuevos operadores. Se concretan en cuatro actuaciones: 1) cesión de franjas horarias, 2) permitir a nuevos operadores participar en los programas de fidelización de clientes, 3) elaboración de acuerdos interlínea y de prorrateo y 4) facilitar la celebración de acuerdos de transporte intermodal. A partir de estos compromisos, que modulan los acuerdos inicialmente notificados, la Comisión, con fecha 7 de abril de 2004, adopta una Decisión por la que se declaran exentos con base en el art. 81.3 TCE, de la prohibición del art. 81.1 TCE, por un periodo de seis años, los acuerdos de transporte aéreo regular de pasajeros propuestos por las sociedades Air France y Alitalia, dejando al margen de la exención el acuerdo relativo al transporte aéreo de mercancías, aún pendiente de negociación, y el acuerdo sobre los servicios de asistencia en tierra, por estar excluido del ámbito de aplicación material del Reglamento 3975/87.

\section{Mercedes Sabido Rodríguez}


Caso N. ${ }^{\circ}$ 2. Ententes: STJCE 29 abril 2004, C-359/01 P, British Sugar plc/Comisión

NotA

10. British Sugar plc interpone, ante el TJCE, recurso de casación contra la sentencia de 12 de julio de 2001 dictada por el Tribunal de Primera Instancia en los asuntos acumulados T-202/98, T-204/98 y T-207/98. La resolución recurrida desestimó los recursos de anulación interpuestos por Tate \& Lyle plc, British Sugar plc y Napier Brown \& Co. Ltd, contra la Dec.Com. 14 octubre 1998, relativa a un procedimiento de aplicación del art. 85 TCE, en la que se impone a las recurrentes multas por infracción del art. 81.1 TCE.

11. En su sentencia, el TPI desestimó las alegaciones de British Sugar plc, recurrente en casación, confirmando la Decisión de la Comisión en el sentido de considerar que la actuación de aquella constituía una práctica concertada prohibida por el art. 81.1 TCE.

El precepto citado prohíbe los acuerdos, decisiones de asociaciones de empresas o prácticas concertadas entre empresas que restrinjan la competencia afectando al comercio entre los Estados miembros. Tratándose de conceptos autónomos, los tribunales comunitarios han ido delimitando el concepto de acuerdo, decisión o práctica concertada del precepto citado, considerando que en el mismo son subsumibles todo acuerdo de voluntad, expreso o tácito, entre empresas. Admitiéndose que las ententes pueden adoptar una pluralidad de formas, en todas ellas aparece como común denominador la concurrencia de una pluralidad de voluntades (A.L. Calvo Caravaca/J. Carrascosa González, Mercado único y libre competencia en la Unión Europea, 2003 , pp. 855 y ss). La calificación de una actuación como acuerdo en el sentido del art. 81.1 TCE debe efectuarse, por tanto, tomando en consideración el contexto real en el que el mismo se desarrolla. En esta línea, el TPI en la sentencia recurrida considera práctica concertada la celebración de distintas reuniones entre empresas del mercado del azúcar. Entiende el tribunal que estas reuniones en las que, como ha quedado acreditado, British Sugar plc informó de sus precios en el mercado del azúcar, pueden considerarse como un acuerdo en el sentido del art. 81.1 TCE. Analizado el mercado de referencia, la posición que ocupan las partes en el mismo y el contenido y naturaleza de las reuniones concluye que son actos de coordinación a través de los cuales British Sugar plc condiciona la conducta de otras empresas asistentes en el mercado del azúcar, al reducir la incertidumbre sobre las conductas relativas a los precios del mayor productor de azúcar inglés. Además, a esta circunstancia se añaden otros elementos, también acreditados en el proceso, como la intención tanto de la empresa ahora recurrente como de la sociedad Tate \& Lyle de excluir las importaciones en este sector del mercado. 
Quizá ninguno de los datos, objetivos y subjetivos a los que se ha hecho referencia, entre otros, las reuniones en las que se informa de precios y la intención de las empresas, hubieran podido servir para justificar, de forma aislada, la calificación de la actuación como una práctica concertada. Sin embargo, analizados conjuntamente, acreditan que más que una mera intención informativa se trataba de una información tendente a impedir las importaciones de azúcar en el Reino Unido.

12. La Comisión se hace eco de las novedades que introdujo la STPI en relación con el concepto de acuerdo, decisión o práctica concertada del art. 81.1 TCE en las directrices relativas a la aplicación del apartado 3 del art. 81 del Tratado (DO C 101 de 27 abril 2004) al señalar que existe una coordinación de comportamientos o colusión entre empresas a efectos del 81.1 TCE cuando «(...) de resultas de contactos entre ambas empresas, desaparezca o, al menos, quede sustancialmente reducida la incertidumbre sobre sus conductas en el mercado» (cdo. 15).

13. El TJCE en la sentencia de 29 abril 2004, desestimando las pretensiones de la recurrente, confirma la resolución impugnada. Dos son los motivos en los que British Sugar plc fundamenta el recurso de casación solicitando la anulación de la sentencia recurrida y de la decisión controvertida: la incidencia sobre el comercio entre Estados miembros y la desproporcionalidad de la multa impuesta. Por su interés, centraremos nuestra atención en el análisis que el TJCE realiza del primero de ellos.

14. Alega la recurrente que el TPI erró al apreciar la incidencia de las reuniones controvertidas en el comercio de los Estados miembros. En su opinión, una práctica colusoria que se extiende al territorio de un Estado miembro no tiene, en sí misma, influencia sobre el comercio entre Estados miembros, debiendo acreditarse, para que tal actuación sea subsumible en el ámbito del art. 85.1 TCE, que el supuesto efecto potencial sobre los intercambios entre Estados miembros es sensible. De este modo, considera que los hechos en los que el tribunal fundamenta su decisión no acreditan que la práctica concertada tenga efectos sensibles sobre los intercambios entre Estados miembros.

Para que un acuerdo, decisión o práctica concertada esté prohibido con base en el art. 81.1 TCE, debe restringir la competencia afectando al comercio entre Estados miembros. Debe, pues, valorarse si el acuerdo restringe o no la competencia. Valoración que ha de efectuarse atendiendo al contexto real en el que se desarrollaría la competencia de no existir dicho acuerdo. Éste estará prohibido cuando sea probable que tenga sensibles efectos negativos sobre la competencia en el mercado de referencia, afectando a los precios, la producción, la calidad o variedad de productos, o la 
innovación. A efectos del art. 81.1 TCE, debemos distinguir los acuerdos que tienen por objeto restringir la competencia, de aquellos otros que, aun no teniendo este objeto, tienen como efecto la restricción de la competencia. Esto es, se distinguen las restricciones por objeto y las restricciones por efecto. Para enmarcar, dentro de esta clasificación, los distintos acuerdos deben analizarse su naturaleza y contenido, su finalidad, el contexto el que se desarrolla así como la conducta y el comportamiento de las empresas que en él participan. Las reuniones celebradas entre varias empresas intervinientes en el mercado del azúcar a través de las cuales una de ellas, la única transformadora británica que produce azúcar a partir de la remolacha, informa de sus precios, se configura como acuerdo que tiene por objeto restringir la competencia. De otra parte, como ha quedado acreditado, esta empresa junto con Tate \& Lyle, también participante en las reuniones, tenían intención de limitar la competencia. Aun no resultando decisivo este elemento subjetivo para calificar la conducta, si es un dato relevante para confirmar que nos encontramos ante un acuerdo que tiene por objeto restringir la competencia. Siendo así, no es necesario acreditar que este efecto negativo sobre la competencia se produce. No es necesario demostrar la existencia de estos efectos reales de restricción de la competencia. Son restricciones que, por su propia naturaleza poseen el potencial de restringir la competencia.

Tratándose de acuerdos que restringen la competencia las normas comunitarias exigen que afecten al comercio entre Estados miembros. Afectación y restricción son elementos independientes. La afectación al comercio entre Estados miembros es un criterio propio de Derecho comunitario a través del cual se determina el ámbito de aplicación de las normas de la competencia. Limita el alcance de los arts. 81 y 82 TCE. Frente a las alegaciones de la recurrente, el TJCE considera que el hecho de que una práctica colusoria se extienda al territorio de un Estado miembro no es suficiente para excluir que la misma pueda afectar a los intercambios intracomunitarios. Debe analizarse, atendiendo a las circunstancias de hecho y de Derecho que rodean el supuesto, que tal actuación no afecta al comercio entre Estados miembros. En esta línea, la política de precios de British Sugar plc y otras empresas participantes en las reuniones, se extendía al territorio del Reino Unido. Para determinar si esta conducta produce efectos en los intercambios intracomunitarios debe analizarse, como acertadamente realiza el Tribunal en la resolución recurrida, las circunstancias que rodean el supuesto. Debe delimitarse el mercado del producto de referencia, que se define como el mercado del azúcar blanco granulado, y la posición de las empresas en el mismo, llegando a concluir que los participantes en las reuniones representaban casi el 90\% del azúcar comercializado en dicho Estado miembro. Como afirma el TPI, tratándose de un mercado permeable a las importaciones, los partici- 
pantes en una práctica colusoria relativa a los precios interiores sólo pueden conservar su cuota de mercado protegiéndose contra la competencia extranjera (STJCE 11 julio 1989, Belasco y otros/Comisión, 246/86, Rec. p. 2117). A partir de estos datos, la posibilidad de que tal actuación pueda afectar a los intercambios entre Estados miembros es muy elevada. Se puede, por tanto, presumir, con probabilidad suficiente que la conducta de la recurrente puede influir, directa o indirectamente, sobre las corrientes de intercambios intracomunitarios, en el sentido de perjudicar la realización de los objetivos de un mercado único entre Estados miembros (SSTJCE de 9 de julio de 1969, Völk, 5/69, Rec. p. 295, apartado 5; de 29 de octubre de 1980, Van Landewyck y otros/Comisión, asuntos acumulados 209/78 a 215/78 y 218/78, Rec. p. 3125, apartado 171, y de 31 de marzo de 1993, Ahlström Osakeytihö, asuntos acumulados C-89/85, C-104/85, C-114/85, C-116/85, C-117/85 y C-125/85 a C-129/85, Rec. p. I-1307, apartado 143; SSTPI de 22 de octubre de 1997, SCK y FNK/Comisión, asuntos acumulados T-213/95 y T-18/96, Rec. p. II-1739, apartado 175, y de 8 de octubre de 1996, Compagnie maritime belge transports y otros/Comisión, asuntos acumulados T-24/93 a T-26/93 y T-28/93, Rec. p. II-1201, apartado 201).

\section{Mercedes Sabido Rodríguez}

Caso N. ${ }^{o}$ 3. Ententes: STPI de 29 de abril de 2004, Tokai carbón Co. Ltd y otros/Comisión de las Comunidades Europeas As. T-236/01, T-239/01, T-244/01, T-245/01, T-246/01, T-251/01 y T-252/01

\section{NotA}

15. La sentencia resuelve el recurso formulado por distintas empresas productoras de electrodos de grafito frente a la Decisión de la Comisión 2002/271, de 18 de julio de 2001 relativa a un procedimiento de conformidad con el artículo 81 TCE.

En enero de 2000 la Comisión emite un pliego de cargos contra las empresas Tokai (Japón), SGL (Alemania), Nipón (Japón), Showa (Japón), Graftech (Estados Unidos), SEC (Japón), Carbide (Estados Unidos) demandantes, y contra VaW (Alemania) por haber procedido, a escala mundial, a fijar precios y repartir mercados nacionales y regionales.

La duración de la infracción se establece con carácter general entre mayo de 1992 y 1998 aunque no en todas las empresas la participación se establece en las mismas fechas.

Por todo ello se imponen a las empresas multas de diversa cuantía y un período de pago de las mismas.

Los hechos de los que trae causa el asunto se producen ante un grupo de empresas de diversas nacionalidades entre las que se encuentran las ci- 
tadas (alemanas, norteamericanas y japonesas) que abastecían el mercado europeo de electrodos de grafito.

Cabe destacar que en 1997 funcionarios de la Comisión llevan a cabo inspecciones por sorpresa en los locales de diversas empresas en Alemania y en Francia, el mismo día en que el FBI realizó investigaciones en los locales de varios productores a raíz de los cuales se incoan procedimientos penales contra algunas de las empresas por conspiración. Todas ellas fueron halladas culpables y condenadas al pago de multas de diversa cuantía por parte de las autoridades americanas.

Junto con las sanciones de carácter penal, un grupo de compradores ejercita en Estados Unidos acciones civiles para reclamar daños y perjuicios contra las empresa infractoras.

En Canadá se siguen igualmente procedimientos penales contra las empresas que fueron declaradas culpables y aceptaron el pago de una multa. Igualmente se ejercieron acciones civiles contra algunas de las empresas.

Las pretensiones de las empresas puede resumirse en una anulación o reducción sustancial de las multas impuestas tomando como base el hecho de que la Comisión no había tenido en cuenta las sanciones impuestas a las empresas por otras autoridades de competencia o que no había aplicado correctamente el documento de cálculo de las sanciones o el de cooperación. En algún supuesto se solicita la anulación de la decisión por contener hechos no considerados veraces.

Los argumentos de las partes se pueden resumir del siguiente modo.

16. Se alega falta de respeto a los derechos de defensa al no facilitarse acceso completo al expediente entendiendo por tal el acceso a los documentos internos de la Comisión y una lista y resumen no confidencial de los citados documentos. $\S 37$.

El TPI aclara que la Comisión debe poner de manifiesto el contenido íntegro del expediente de instrucción a excepción de los documentos que contengan secretos comerciales de otras empresas u otros documentos internos de la Comisión. Sin embargo, la demandante no formuló petición alguna en este sentido durante el procedimiento y la Comisión no está obligada a facilitar esta información a iniciativa propia $\$ 39$. Por otra parte, el acceso a los documentos internos de la Comisión sólo se justifica en los casos excepcionales, basados en indicios serios que corresponde a la parte interesada facilitar. $\$ 40$.

17. Se alega el carácter no definitivo del pliego de cargos. Cabe recordar en este punto, tal como lo hace el Tribunal $\S 45$, que el procedimiento establecido por la Comisión no está dividido en dos fases independientes como sucede en los procedimientos penales internos de muchos ordenamientos de los Estados. De hecho, se considera posible que la Comisión 
comunique a las partes interesadas nuevos documentos que considere que apoyan su tesis, después de emitir el pliego de cargos, siempre que las empresas tengan tiempo suficiente para expresar su opinión al respecto. El respeto al derecho de defensa de las partes se considera respetado si los interesados pueden conocer efectivamente los comportamientos que les reprocha la Comisión y este requisito se cumple cuando la decisión final no imputa a los interesados infracciones diferentes de las mencionadas en el pliego de cargos y cuando sólo tiene en cuenta hechos sobre los que han tenido posibilidad de justificarse. $\$ 47$.

18. Sobre la labor del Consejero auditor se plantea el hecho de que al no incluir en su informe todas las pretensiones de las partes, éste se convierte en ilegal.

Sobre esta cuestión aclara el Tribunal que no le corresponde al Consejero reunir todos los motivos de orden procesal invocados por los interesados durante el proceso administrativo, sino únicamente los motivos pertinentes para apreciar si el procedimiento administrativo se desarrolló legalmente.

19. Se alega que la Comisión no ha acreditado de modo suficiente la participación de una de las empresas en la infracción, teniendo en cuenta que la carga de la prueba de la infracción recae en la parte que la alega.

En respuesta a esta afirmación se establece que, en caso de que la empresa no hubiera estado de acuerdo con las afirmaciones de la Comisión, debería haberlas rebatido en su respuesta al pliego de cargos porque de ese modo, la Comisión podría haber profundizado en sus investigaciones y aportar pruebas adicionales. Sin embargo la empresa no consultó el expediente ni compareció a la audiencia subrayando su voluntad de cooperación con el fin de pretender reducir la cuantía de la multa. § 106.

El Tribunal considera que, si bien no existe reconocimiento expreso por parte de la empresa inculpada por el hecho de acceder a colaborar, la Comisión debe acreditar los hechos y la empresa disfruta de la libertad de desarrollar en el marco del procedimiento contencioso todos los motivos de defensa que considere oportunos, cuando la empresa ha reconocido en el procedimiento administrativo la veracidad de los hechos de manera expresa, clara y precisa, los hechos deben considerarse probados sin que sea posible para la empresa impugnarlos en el contencioso. \$108 Cuando la conclusión no se deriva de una aceptación expresa sino de un conjunto de elementos como el comportamiento objetivo con la Comisión, declaraciones generales y no negación de los hechos, no puede impedirse a la empresa que alegue los hechos ante el Tribunal.

Ello no obstante, el Tribunal, en ejercicio de su competencia de plena jurisdicción, incrementa la multa a la citada empresa considerando que, después de haberse beneficiado de una reducción de la multa por no haber 
discutido la materialidad de los hechos tenidos en cuenta por la Comisión en el procedimiento administrativo pone en tela de juicio la veracidad de esos hechos por primera vez ante el Tribunal de Primera Instancia. § 113.

20. Una de las cuestiones más relevantes y controvertidas de la sentencia que se está analizando es la alegación de violación del principio de no acumulación de sanciones impuestas por la Comisión de autoridades de terceros Estados.

Las alegaciones de las partes en este sentido, pueden resultar interesantes.

Mantienen que la regla de no acumulación de sanciones por una misma infracción está basada en los principios de equidad y proporcionalidad, y que ambos principios se encuentran reconocidos por el Derecho Constitucional de la Unión Europea, y han sido confirmados por el artículo 50 de la Carta de los Derechos Fundamentales de la Unión Europea, proclamada el 7 de diciembre de 2000 en Niza (DO 2000, C 364, p. 1), por los artículo 54 a 58 del Convenio de aplicación del Acuerdo de Schengen, de 14 de junio de 1985, entre los Gobiernos de los Estados de la Unión Económica Benelux, de la República Federal de Alemania y de la República Francesa relativo a la supresión gradual de los controles en las fronteras comunes (DO 2000, L 239, p. 19), firmado el 19 de junio de 1990 en Schengen (Luxemburgo). Además, el principio non bis in idem se protege igualmente por el artículo 4 del Protocolo n. ${ }^{\circ} 7$ del Convenio Europeo para la Protección de los Derechos Humanos y de las Libertades Fundamentales (CEDH), suscrito en Roma el 4 de noviembre de 1950, tal como lo interpreta, en particular, la sentencia del Tribunal Europeo de Derechos Humanos de 29 de mayo de 2001, Fischer c. Austria.

Tal como ya se había recogido en sentencias precedentes, partiendo de la ya clásica del Tribunal de Justicia de 14 de diciembre de 1972, Boehringer/ Comisión (7/72, Rec. p. 1281), la Comisión debe tener en cuenta las sanciones impuestas a las empresas cuando los hechos de que se les acusa sean idénticos en los distintos procedimientos sancionadores. Según las alegaciones de las partes, la Comisión, no reduciendo la cuantía de las sanciones en este caso, contradice también la jurisprudencia del Tribunal en las sentencias del Tribunal de Justicia de 13 de febrero de 1969, Walt Wilhelm y otros (14/68, Rec. p. 1), apartado 11, así como las sentencias del Tribunal de Primera Instancia de 6 de abril de 1995, Sotralentz/Comisión (T-149/89, Rec. p. II-1127), apartado 29, y de 20 de abril de 1999, Limburgse Vinyl Maatschappij y otros/ Comisión (asuntos acumulados T-305/94 a T-307/94, T-313/94 a T-316/94, T-318/94, T-325/94, T-328/94, T-329/94 y T-335/94, Rec. p. II-931), § 96, según las cuales la exigencia general de equidad implica que, al fijar la cuantía de una multa, la Comisión está obligada a tener en cuenta las sanciones que 
se hayan impuesto a la misma empresa por el mismo hecho. Se contradirían además las afirmaciones realizadas por el Director General de la Competencia, Alexander Schaub, que habría afirmado que se descontarían las sanciones impuestas por autoridades de Estados Unidos. § 124.

No puede desconocerse, según las demandantes, que la Comisión reconoce en su decisión el carácter mundial de los acuerdos que son objeto de infracción y sanción.

Se subraya igualmente por alguna de las empresas que las sanciones impuestas por las autoridades procedentes de terceros Estados superan ya el límite máximo de las sanciones que puede imponer la Comisión (recogido en el momento de la Resolución en el art. 15 del entonces vigente R. 17).

En cualquier caso, además, debería subrayarse que la Comisión habría empleado como base para el cálculo de las sanciones el volumen de negocios mundial de las empresas, cuando el desvalor correspondiente a la infracción en los mercados estadounidense y canadiense se habría sin duda tenido en cuenta en los procedimientos seguidos por las autoridades extranjeras. Así consideran las empresas que el mercado relevante para calcular el monto de la sanción, debería ser el mercado europeo.

En el mismo sentido, se considera que uno de los elementos que la Comisión tiene en cuenta al calcular el montante de una sanción es el efecto disuasorio de la misma, efecto que ya se habría cubierto por las sanciones impuestas por las autoridades de los terceros Estados.

21. La Comisión consideró que las sanciones impuestas por otras autoridades sólo tienen en cuenta los efectos contrarios a la competencia del cártel en el ámbito territorial de esas autoridades y que un mismo hecho puede constituir una infracción para varios ordenamientos jurídicos. Sobre el posible efecto disuasorio, alega que el principal criterio de cálculo de las sanciones es la gravedad de las infracciones, por lo que éste no podría ser elemento que justifique la reducción de la sanción.

22. El Tribunal de Primera Instancia comienza reconociendo la relevancia del principio non bis in idem. Precisa, sin embargo, su alcance y cuestiona su aplicación a los hechos objeto de análisis.

Comienza afirmando que en el ámbito del Derecho de la competencia comunitario, dicho principio prohíbe que se condene a una empresa o que la Comisión inicie de nuevo un procedimiento sancionador en su contra por un comportamiento contrario a la competencia a causa del cual ya haya sido sancionada o del que la Comisión la haya declarado no responsable mediante una decisión anterior que no puede ser objeto de recurso. De la citada afirmación parecería desprenderse que lo relevante sería la identidad de comportamiento, siendo indiferente cuál fuese la autoridad que hubiese sancionado previamente. 
Sin embargo, siguiendo con la doctrina que había venido afirmando desde las sentencias históricas en la materia, el Tribunal continúa precisando las siguientes cuestiones.

El principio no recibiría aplicación en los casos en que los procedimientos sancionadores iniciados tomando como base los mismos hechos, persiguiesen objetivos diferentes. Es lo que tradicionalmente se ha venido en denominar la teoría de la relevancia del interés jurídicamente protegido (Sentencia del Tribunal de Justicia de 15 de julio de 1970, Buchler/ Comisión, 44/69, Rec. p. 733, § 52 y 53 y las conclusiones del Abogado General Ruiz-Jarabo Colomer de 11 de febrero de 2003, Italcementi/Comisión, C-213/00 P, Rec. p. I-0000, § 89). En su afirmación parece igualmente que el Tribunal reconoce relevancia a cual fuera la autoridad que hubiese iniciado el proceso sancionador, dado que asume la acumulación de sanciones, cuando los procedimientos se hayan iniciado por autoridades nacionales y comunitarias. Siguiendo con la doctrina asentada, el respeto del principio de proporcionalidad exigirá que al fijar la cuantía de una multa, la Comisión tenga en cuenta las sanciones que ya se han impuesto a la misma empresa por el mismo hecho, si se trata de sanciones impuestas por infracciones al Derecho de la competencia de un Estado miembro y, por consiguiente, cometidas en territorio comunitario.

El Tribunal de Justicia considera que el artículo 4 del Protocolo n. ${ }^{\circ} 7$ del CEDH implica que los tribunales de un Estado no podrían juzgar o sancionar una infracción por la que la persona procesada ya haya sido absuelta o condenada en dicho Estado. En cambio, el principio non bis in idem no prohíbe que una persona sea procesada o sancionada más de una vez por un mismo hecho en dos o más Estados distintos. Por consiguiente, la sentencia Fischer c. Austria, carece de pertinencia en el presente litigio, ya que fue dictada con arreglo al artículo 4 del citado Protocolo y se refiere a dos condenas pronunciadas en un mismo país. La aplicación del principio con carácter internacional sólo podría derivarse de la aplicación de normas de carácter internacional que vincularan a los distintos Estados afectados inmersos en un proceso de integración. El artículo 50 de la Carta de Derechos Fundamentales, establece que nadie podrá ser acusado o condenado penalmente por una infracción respecto de la cual ya haya sido absuelto o condenado en la Unión mediante sentencia penal firme conforme a la ley. Ese texto sólo podría aplicarse en el caso de que exista una resolución absolutoria o de condena que haya sido pronunciada en el territorio comunitario.

Así, el hecho de que la confluencia de sanciones en el caso que se analiza se produzca respecto de otras impuestas por autoridades procedentes de terceros Estados se analiza desde dos perspectivas diferentes:

La primera teniendo en cuenta que no existe Convenio Internacional vigente entre los países afectados en que se reconozca la vigencia del prin- 
cipio non bis in idem. Los convenios internacionales vigentes en la Unión y que por lo tanto inspiran la actuación de la Comisión, no vinculan al resto de autoridades que han sancionado las conductas en el caso que nos ocupa. De hecho, según las opiniones vertidas por el Tribunal, podría considerarse un presupuesto para que pudieran existir los citados Convenios el hecho de que existieran normas comunes en materia de defensa de la competencia.

Además, el hecho de proceder las sanciones de autoridades procedentes de terceros Estados, implicaría casi por definición la existencia de intereses jurídicamente protegidos diferentes en los procedimientos en presencia. El hecho de que los acuerdos sancionados tuvieran escala mundial, y que ese hecho fuera reconocido por las autoridades estadounidenses o canadienses, no implicaría que las autoridades de los citados países hubieran impuesto las sanciones teniendo en cuenta el desvalor completo de las acciones sancionadas. De hecho, en el caso de que esas autoridades hubieran tenido en cuenta los efectos de los acuerdos en el mercado comunitario podría incluso considerarse una injerencia inaceptable en la jurisdicción de la Comisión.

Algo parecido podría decirse de la alegación realizada por las partes en virtud de la cual las sanciones impuestas previamente por las autoridades de terceros Estados hubieran cubierto la función disuasoria exigiendo una moderación de la sanción. La Comisión tiene encomendada la función de proseguir la política general en materia de competencia y las sanciones impuestas por otras autoridades no pueden menoscabar su función sancionadora.

Por todas estas razones el Tribunal desestima las pretensiones de las demandantes.

23. Resulta interesante, por divulgativo, el análisis que hace la sentencia de la Comunicación sobre cómputo de las sanciones y la clasificación que realiza de las infracciones, teniendo en cuenta su gravedad, naturaleza, incidencia en el mercado y duración para considerarla infracción muy grave y posteriormente la clasificación que realiza de las empresas participantes en tres categorías para moderar el importe concreto de las sanciones, la determinación de las circunstancias agravantes y atenuantes.

Las empresas reprochan a la Comisión, haberse apartado del criterio del volumen de negocios para establecer el montante de las sanciones, tomar en consideración el volumen de negocios mundial y no probar que la elevación de los precios dependiera del cártel, separarse del precedente estableciendo sanciones claramente superiores a las que se habían impuesto hasta ese momento. Este argumento se vincula con la quiebra del principio de proporcionalidad en el cómputo de la sanción. Las empresas japonesas alegaron igualmente que a la hora de determinar el importe 
de las sanciones, debería haberse tenido en cuenta tan sólo el volumen de negocio en el EEE porque de otro modo se vulneraría la competencia territorial de la Comisión e igualmente se permitiría realmente medir la capacidad real de cada empresa de perjudicar seriamente la competencia en el EEE.

El Tribunal precisa que las Directrices sobre cálculo de las multas (de 1998, posteriores al momento en que se lleva a cabo la infracción) son aplicables porque no constituyen una alteración del marco jurídico establecido en el Reglamento 17 por lo que no vulneran el principio de irretroactividad ni el de seguridad jurídica. Por otra parte, los precedentes no implican que la Comisión no pueda agravar las penas.

Respecto de la elección del volumen de negocios, la Comisión puede, según la precisión del Tribunal partir del volumen de negocios de su elección en términos de base geográfica y de productos afectados. § 195.

En ese caso, ¿es razonable que se tome como base el volumen de negocios global de las empresas para calcular el importe de las sanciones cuando se permite que autoridades de terceros Estados sancionen el mismo comportamiento sin que quepa siquiera una moderación de las sanciones impuestas? El respeto del principio de proporcionalidad, el de intereses jurídicos protegidos, así como el respeto estricto del principio non bis in idem, deberían llevarnos a una interpretación diferente que supondría, la toma en consideración de las sanciones impuestas, si no, en algunos casos, la imposibilidad de nuevo enjuiciamiento o sanción.

Maria Pilar Canedo Arrillaga

Caso N. ${ }^{\circ}$ 4. Ententes: Sentencia del Tribunal de Primera Instancia de 29 de abril de 2004, Tokai carbón Co. Ltd y otros/Comisión de las Comunidades Europeas As. T-236/01, T-239/01, T-244/01, T-245/01, T-246/01, T-251/01 y $T-252 / 01$

NotA

24. La sentencia objeto de análisis es resultado de un recurso ante la Decisión de la Comisión 5083 de 17 de diciembre de 2002 en que se sanciona un set de acuerdos empresariales realizado por un grupo de empresas productoras de grafito especial.

Las empresas sujeto de la decisión de la Comisión habían sido objeto de investigación por parte de las autoridades estadounidenses que, tras encontrarlas culpables, habían decidido imponerles sanciones elevadas en el marco de un proceso penal. Las empresas solicitan la anulación de la Decisión de la Comisión o, subsidiariamente, la reducción en el importe de las multas impuestas. 
25. Basan las demandantes sus alegaciones en diversos argumentos de entre los que destacaremos los fundamentales. Comienza la argumentación aduciendo que las empresas sancionadas no han tomado partido realmente en las infracciones al no haber participado las representantes de las empresas sancionadas en las reuniones más relevantes de alto nivel en que habían tomado las decisiones en que adoptan las medidas objeto de la infracción y por las relaciones de dependencia existentes entre las sucursales y las casas matrices que hacían imposible para las primeras llevar a cabo conductas de manera independiente de las segundas.

El Tribunal, basándose en la definición de empresa clásica del Derecho Comunitario y perfilada por el propio Tribunal y teniendo en cuenta las empresas realmente sancionadas no habían realizado labores que supusieran desmarcarse de las prácticas sancionadas, éstas deben considerarse responsables.

26. Uno de los argumentos fundamentales de la sentencia hace referencia a las alegaciones de las partes en relación con el posible cúmulo de sanciones que supone la decisión. Los hechos objeto de la misma habían sido sancionados previamente por parte de las autoridades estadounidenses de defensa de la competencia. Las sanciones impuestas por las autoridades de terceros Estados no se habían tenido en cuenta por la Comisión al calcular el importe de sus sanciones.

El Tribunal considera en su resolución que en los casos en que las infracciones estén basadas en el mismo grupo de acuerdos pero tengan diferentes objetos y ámbitos geográficos de aplicación, el principio non bis in idem no resultaría de aplicación.

Se rechaza igualmente por el Tribunal la alegación realizada por las partes en virtud de la cual en caso de asumir que se van a poder imponer dos sanciones no cabe calcular el volumen de negocio de la empresa sancionada basándose en el volumen de negocios mundial, dado que de este modo se sancionaría el desvalor que implican los hechos en más de una ocasión. Se mantiene de este modo que la toma en consideración del volumen de negocios sirve a la Comisión para analizar el impacto de las empresas en el mercado mundial afectado por la infracción.

27. Las empresas aducen igualmente una quiebra el principio non bis in idem al mantener la relación existente entre el asunto objeto de estudio y el denominado cártel de grafito en que las empresas habían sido sancionadas dentro de la Comunidad Europea por parte de la Comisión por un acuerdo conectado con el que en este momento se analiza

La Comisión, respaldada en este punto por el Tribunal, mantuvo en su decisión que los acuerdos objeto de los dos asuntos eran absolutamente diferenciados, razón por la cual no hay lugar a plantear una prohibición de 
la doble sanción. No en vano, al ser los productos objeto de sanción, totalmente diferenciados, el hecho de que las empresas sancionadas coincidan no puede llevarnos a considerar que no se pueden imponer sanciones distintas. De otro modo, el beneficio económico que implica la infracción no sería sancionado en su totalidad y el desvalor generado no sería totalmente paliado.

28. Las alegaciones que hacen referencia a la protección de los derechos de defensa de las empresas partícipes se centran fundamentalmente en los derechos de audiencia, aunque las alegaciones son en realidad fácticas más que jurídicas, lo mismo que sucede con las circunstancias agravantes y atenuantes en que se analiza la mejor manera de aplicar las Directrices para el cálculo de las multas de 1998, sin que jurídicamente existan aportaciones dignas de ser destacadas en la resolución que comentamos.

29. En este caso se plantea la aplicación de las directrices sobre clemencia por cooperación directa con la Comisión. En este punto la discusión se centra, realmente en la naturaleza de las pruebas facilitadas por las partes a la Comisión. Así, si éstas no pueden considerarse «decisivas», no cabe esperar que reducciones sustanciales de las multas. Debe aclararse que las empresas no deben facilitar todas las pruebas necesarias para acreditar la infracción, pero sí resulta necesario que las pruebas facilitadas sean parte de las consideradas decisivas en la investigación.

María Pilar Canedo Arrillaga

Caso N. ${ }^{\circ}$ 5. Ententes: STPI 8 julio 2004, Mannesmannröhren-Werke/ Comisión, T-44/00; STPI 8 julio 2004, Corus/Comisión, T-48/00; STPI 8 julio 2004, Dalmine/Comisión, T-50/00; STPI 8 julio 2004, asuntos acumulados JFE Engineering/Comisión, T-67/00, Nippon Steel/Comisión, T-68/00, JFE Steel/Comisión, T-71/00, y Sumitomo Metal Industries/ Comisión, $T-78 / 00$

NotA

30. La parte demandante en estos procesos recurrió ante el TPI la Dec. Com. 8 diciembre 1999, Tubos de acero sin soldadura, DO L 140 de 6 junio 2003. Según esta Decisión, ocho empresas fabricantes de tubos de acero sin soldadura, cuatro europeas y cuatro japonesas, habían infringido el art. $81 \mathrm{TCE}$, al haber formado una entente, en virtud a la cual, se comprometían a respetar los mercados nacionales de las demás empresas. Las empresas infractoras habían celebrado acuerdos en el marco del llamado Club Europa-Japón. En esas reuniones acordaron respetar los mercados nacionales de las demás participantes, en lo que respecta a la venta de tubos 
estándar - tubos de sondeo, que pueden ser lisos o con rosca-y tubos de transporte - de petróleo y gas - .

La Comisión también consideró que las empresas comunitarias habían pactado el reparto del mercado del Reino Unido, en relación con la venta de tubos lisos, y que este comportamiento constituía otra práctica ilícita en virtud del art. 81 TCE; si bien no la sancionó por entender que no era más que un instrumento para poder seguir respetando las normas creadas en el seno del Club Europa-Japón.

31. Siete de las ocho empresas destinatarias de la Decisión interpusieron recurso contra la misma ante el TPI. En cada recurso hay motivos diferentes aducidos en contra de la Decisión antes mencionada; sin embargo, las alegaciones respecto del importe de la multa impuesta fueron similares - al menos en lo que se refiere a la aplicación de las Directrices para el cálculo de las multas impuestas en aplicación del art. 15.2 del Reglamento $n .^{\circ} 17$ y del art. $65.5 \mathrm{del}$ Tratado CECA. Las respuestas del TPI respecto de este tema, por supuesto, también fueron las mismas.

32. En el comentario que a continuación se expone, se ha tenido como referencia principal la STPI T-44/00, salvo algún aspecto que expresamente se señalará. Se debe tener en cuenta, por tanto, que las consideraciones que realiza el TPI en esta sentencia, siempre respecto a la aplicación de las Directrices, son trasladables al resto de sentencias en la que medida en que coincidan los motivos alegados por las partes en relación con dichas Directrices.

33. El TPI determinó que la Comisión tiene margen de apreciación a la hora de fijar el importe de las multas impuestas, con los límites que recoge el Reglamento n. ${ }^{\circ} 17$ - en la actualidad derogado por el Reglamento $1 / 2003$ - (apartado 228), y «respetando el Derecho comunitario, que no sólo incluye las disposiciones del Tratado, sino también los principios generales del Derecho» (apartado 572 de los asuntos acumulados T-67/00, T-68/00, T-71/00, T-78/00). No obstante, prosiguió el Tribunal, la Comisión no puede obviar las normas que se ha dado a sí misma y, por ello, debe tener en cuenta lo recogido en las Directrices (apartado 231). Por tanto, al determinar la gravedad del comportamiento, la Comisión deberá considerar la naturaleza de la infracción, las repercusiones concretas sobre el mercado y la dimensión del mercado geográfico afectado (punto 1.A] de las Directrices).

34. La Comisión, según el TPI, tuvo en cuenta el pequeño tamaño del mercado afectado (19\%), para reducir en un 50\% la multa mínima que se debe imponer en el caso de infracciones muy graves (apartado 241). El reparto del mercado es un infracción calificada por la Comisión en las Di- 
rectrices como muy grave y el importe mínimo de la multa a imponer debía ser de 20 millones de ecus: la Comisión impuso una multa de 10 millones de ecus. Esta reducción del 50\% del importe mínimo de la multa se consideró suficiente, debido a que, si fuera mayor, el efecto disuasorio de la multa perdería su razón de ser para infractores que, como los denunciados, disponen de un elevado poder económico (apartado 242, en aplicación del párrafo cuarto del punto 1. A] de las Directrices).

35. Por último, por lo que se refiere a la gravedad de la infracción, el TPI aclara que el límite máximo de multa fijado en el Reglamento n. ${ }^{\circ} 17$, del $10 \%$ del volumen de negocio de la empresa infractora, no debía interpretarse como una consideración del tamaño de aquélla a la hora de fijar la multa. En efecto, el tamaño de la empresa no debe tenerse en cuenta de manera que las multas sean proporcionales a la capacidad económica de los destinatarios de las mismas (apartado 228).

En este mismo sentido, el párrafo sexto del punto 1) A. de las Directrices recoge que «en caso de las infracciones en las que están implicadas varias empresas (cárteles), podrá resultar conveniente ponderar, en determinados casos, los importes fijados dentro de cada una de las tres categorías preexpuestas para tomar en consideración el peso específico y, por tanto, las repercusiones reales del comportamiento ilícito de cada empresa sobre la competencia, sobre todo cuando existe una disparidad considerable en cuanto a la dimensión de las empresas responsables de una infracción de la misma naturaleza». Y, de la misma manera que se expresó el TPI en relación con el límite máximo del $10 \%$ del volumen de negocio, se consideró que la Comisión dispone de flexibilidad a la hora de determinar el importe de la multa, y el tamaño de la empresa infractora es sólo un factor que puede tener en cuenta en los que casos que así lo requieran (apartados 246-247). De cualquier manera, en el presente asunto, las empresas destinatarias de la multa fueron consideradas, todas ellas, empresas de gran dimensión.

36. En cuanto a la repercusión real del comportamiento ilícito de cada empresa, el TPI consideró que la participación de los denunciados en la infracción estaba probada y que la puesta en práctica del acuerdo ilícito conllevó un impacto real sobre las condiciones de competencia en el mercado (apartado 252).

37. La empresa demandante alegó que, si bien es cierto que la Comisión redujo el importe de la multa en un $10 \%$, teniendo en cuenta la circunstancia atenuante relativa a la situación de crisis que vivía el sector siderúrgico en el momento de los hechos, lo cierto es que, según aquélla, la Comisión debía haber reducido aún más la multa por concurrir otras tres circunstancias atenuantes: la no aplicación efectiva del acuerdo, el cese 
de las infracciones desde el momento en que la Comisión comenzó sus investigaciones, y la cooperación de la demandante con la Comisión en el procedimiento (circunstancias atenuantes segunda, tercera y sexta de las Directrices).

38. El TPI consideró que la Comisión no debe tener en cuenta, por separado, cada una de las circunstancias atenuantes concurrentes, a los efectos de reducir la multa en un determinado porcentaje por cada una de ellas. Las circunstancias atenuantes deben considerarse en su conjunto y la Comisión tiene pleno margen de actuación a la hora de fijar el porcentaje que estima oportuno aplicar para reducir la multa, en función a todas las circunstancias que concurran en el supuesto (apartado 274).

Si bien es cierto lo anterior, la Comisión justificó la reducción del 10\% de la multa por la situación de crisis que atravesaba en ese momento el sector siderúrgico; por lo tanto, de concurrir alguna circunstancia atenuante adicional - alegada por la demandante - , el porcentaje a aplicar para rebajar la multa debería ser mayor.

39. Analizando cada una de las tres circunstancias atenuantes alegadas por la demandante, el TPI determinó que:

a) Respecto de la primera, «procede interpretar el segundo guión del punto 3 de las Directrices en el sentido de que la Comisión sólo está obligada a reconocer la existencia de una circunstancia atenuante por falta de aplicación efectiva de una concertación si la empresa que alega dicha circunstancia puede demostrar que se opuso clara y considerablemente a la aplicación de dicha concertación, hasta el punto de haber perturbado el propio funcionamiento de ésta, y que no dio la impresión de adherirse al acuerdo ni incitó así a otras empresas a aplicar el acuerdo ilícito de que se trata. En efecto, una vez que se ha acreditado la participación de una empresa en una concertación con sus competidores para repartir los mercados, el hecho de que la empresa no haya ajustado su conducta en el mercado a la convenida con sus competidores no constituye necesariamente un elemento que deba tenerse en cuenta, como circunstancia atenuante, al determinar la cuantía de la multa que debe imponerse (...)» (apartado 277) - criterio mantenido por el TPI en otras sentencias anteriores, ad ex., STPI 14 mayo 1998, SCA Holding/Comisión, T-327/94, Rec.1998, p. II-1373-.

b) En cuanto a la segunda, el Tribunal consideró que el cese de las infracciones debe venir motivado por el inicio de las actuaciones de la Comisión; por tanto, el comportamiento ilícito de las denunciadas debía existir en el momento en que la Comisión comienza 
sus investigaciones $\mathrm{y}$, precisamente por este comienzo del procedimiento, es por lo que las empresas infractoras debían haber dejado de actuar de forma ilícita - en el caso de autos, el comportamiento ilícito dejó de producirse antes de que la Comisión empezara su actuación (apartados 280 y 281) - . El Tribunal destacó también que la aplicación de esta circunstancia atenuante será menos oportuna cuando el comportamiento ilícito daña la competencia en el mercado de forma evidente - como, de hecho, se ha comprobado que ocurría en este caso (apartado 281) - .

c) Por último, en lo que se refiere a la tercera circunstancia atenuante, el TPI afirmó que el sexto guión del punto tercero de las Directrices hace referencia a una «cooperación efectiva que haya facilitado la labor de la Comisión», pero que no pueda justificar una reducción de la multa al amparo de la Comunicación sobre cooperación (Comunicación de 18 de julio de 1996 relativa a la no imposición de multas o a la reducción de su importe, DO C 207 de 18 julio 1996) (apartado 308). En el presente caso, además, se había comprobado que la cooperación de la demandante no había facilitado la labor de la Comisión en el conocimiento y represión del comportamiento ilícito denunciado (apartado 309).

40. En la STPI T-50/00, el Tribunal analizó como posible circunstancia atenuante, en el marco de las Directrices, otro motivo diferente alegado por la demandante. Se trata de la función pasiva del infractor (primer guión del punto 3) de las Directrices). Sobre esta circunstancia el Tribunal se pronunció, considerando que la empresa demandante no había aportado ninguna prueba que acreditase que su función era meramente pasiva o seguidista. Además, continúa el Tribunal, «lo que llevó a incluir el mercado italiano en el acuerdo de reparto de mercados fue su presencia [de la empresa demandante] en el Club Europa-Japón» (apartado 295).

Juliana Rodríguez Rodrigo

Caso N. ${ }^{\circ}$ 6. Ententes: Dec.Com. 9 diciembre 2004, Cloruro de colina, DO L 190 de 22 julio 2005.

NoTA

41. Los destinatarios (Akzo Nobel, BASF, Bioproducts, Chinook, Ducha y UCB) cometieron una infracción única y continuada del art. 81.1 TCE, y, a partir de 1 enero 1994, del art. 53.1 del Acuerdo del EEE. Tras recibir en abril de 1999 la solicitud de clemencia presentada por el proveedor estadounidense Bioproducts, la Comisión inició una investigación sobre el conjun- 
to de la industria del cloruro de colina (que pertenece al grupo del complejo de vitaminas B hidrosolubles (vitamina B4) y se utiliza principalmente en la industria de alimentación animal como un aditivo alimentario tradicional). Durante el período investigado, los fabricantes que cometieron la infracción controlaban más del $80 \%$ del mercado mundial. Los fabricantes europeos controlaban cerca del $80 \%$ de la zona del EEE.

La Comisión descubrió que los acuerdos adoptados a nivel global y europeo formaban parte conjunta de un plan global que establecía las líneas de actuación de los miembros del cártel del cloruro de colina en el EEE y restringía su actuación comercial individual con el único objetivo económico de falsear las condiciones de competencia normales en ese mercado en el EEE. Los fabricantes norteamericanos participaron en dicho plan entre octubre de 1992 y abril de 1994 (un período de un año y seis meses) y los fabricantes europeos entre octubre de 1992 y septiembre de 1998 (un período de cinco años y once meses). Como la Comisión adoptó las primeras medidas para investigar la infracción el 26 mayo 1999, más de cinco años después de que dejaran de cometer la infracción los fabricantes norteamericanos Bioproducts, Chinook y Ducha, la infracción estaba prescrita respecto de ellos (arts. 1 Rgto. (CEE) 2988/74 y 25 del Rgto (CE)1/2003).

42. La Comisión parte de que la infracción cometida por Akzo Nobel, BASF y UCB, consistente en fijación de precios en el EEE, reforzada por el reparto del mercado y acciones concertadas contra los competidores de mercado, son restricciones horizontales, que, por su propia naturaleza, están entre las más graves violaciones de los arts. 81.1 TCE y 53. 1 del Acuerdo del EEE. Además abarcaban al conjunto del mercado común y, tras su creación, al EEE en su totalidad, a pesar de que no pudiera calcularse su impacto real.

En esta categoría de infracciones muy graves, la escala de multas permite aplicar un trato diferenciado a las empresas a fin de tener en cuenta la capacidad económica efectiva de los infractores para causar un daño significativo a la competencia. Por esta razón, la Comisión utiliza las cuotas de mercado globales de las empresas infractoras para determinar la importancia relativa de cada una de ellas: Chinook, el mayor operador de mercado en el mundo, con una cuota de mercado del 19,3\%, fue incluido en una primera categoría. DuCoa, con una cuota de mercado del 16,3\%, en la segunda categoría. UCB, Bioproducts y Akzo Nobel, con cuotas de mercado del $13,4 \%, 12,2 \%$ y $12,0 \%$, respectivamente, en la tercera categoría. Por último, BASF, con una cuota de mercado del $9,1 \%$, en la cuarta categoría.

En esa categoría de infracciones, la escala de multas también permite imponer multas que garanticen un efecto disuasorio adecuado, según el 
tamaño de cada empresa. En 2003, ejercicio presupuestario anterior a la Decisión, el volumen de negocios de UCB fue de 3.000 millones $€$, el de Akzo Nobel de 13.000 millones $€$ y el de BASF de 33.400 millones $€$. En atención a estas cifras, la Comisión aumenta la multa a Akzo Nobel y a BASF aplicándoles, respectivamente, un factor 1,5 y 2.

43. La Comisión aplica la circunstancia agravante de reincidencia a BASF, aumentándole en un $50 \%$ el importe base de la multa, porque en el período en que se cometió la infracción, ya había sido objeto de decisiones de la Comisión sobre prohibición de actividades de cártel en otros sectores que, a la vista de esta nueva infracción, no la incitaron a cambiar el comportamiento del conjunto de la empresa. No admite como circunstancias atenuantes: que una empresa ponga fin a la infracción antes de la intervención de la Comisión pues esta conducta afecta a la duración de la infracción, no a la realización de la infracción; que no se llevara a cabo la infracción de forma plena o eficaz porque ninguno de los fabricantes que la invocan había indicado que deseara o que hubiera tomado alguna medida para abstenerse deliberadamente de poner en práctica los acuerdos a los que llegaron sobre el EEE durante el período en que los suscribieron; que hubiera durado mucho tiempo la investigación porque el tiempo sólo afecta al plazo de prescripción (según el art. 25.5 del Rgto. 1/2003, la prescripción se reputará alcanzada, a más tardar el día en que se cumpla un plazo igual al doble del de la prescripción, sin que la Comisión haya impuesto ninguna multa sancionadora ni coercitiva); que la industria del cloruro de colina estuviera en situación de crisis porque esta situación no autoriza a realizar una colusión secreta con los competidores para engañar a los clientes y a otros competidores; ni que se hubieran tomado medidas disciplinarias contra los empleados implicados en la infracción y por haber adoptado un programa de cumplimiento, porque tales medidas no pueden cambiar la realidad de la infracción ni la necesidad de sancionarla. La Comisión considera, en cambio, circunstancia atenuante que UCB fuese la primera empresa que informó voluntariamente a la Comisión de que, además de las reuniones a nivel global, los fabricantes europeos habían celebrado una serie de reuniones a nivel europeo que permitieron a la Comisión fijar la duración de la infracción en cinco años y once meses, por lo que le reduce el 25,8 \% del importe base.

44. Se aplica al caso la Comunicación de 1996, porque el punto 28 de la Comunicación de 2002 establece esa posibilidad cuando varias empresas hubieran solicitado clemencia antes del 14 febrero 2002, fecha en que la de 2002 sustituía a la de 1996. En aplicación de esta última Comunicación se establecieron reducciones en la multa a las empresas que cooperaron con la Comisión en diversas fases de la investigación. A BASF se le reduce el $20 \%$ la multa prevista en razón a que las pruebas presentadas 
contribuyeron a determinar la existencia de la infracción y a que, tras recibir el pliego de cargos, no cuestionó sustancialmente los hechos en los que la Comisión basaba sus alegaciones, a excepción de determinadas correcciones de hechos que la Comisión aceptó. A UCB, por haber informado voluntariamente a la Comisión de nueve reuniones del cártel celebradas a nivel europeo, entre 1994 y 1998, haber mencionado a los participantes y haber facilitado una breve descripción general del contenido de las reuniones, en un momento en que la Comisión no tenía conocimiento de ninguna reunión a nivel europeo, le concede una reducción del 30 \%. Este mismo porcentaje fue concedido a Akzo Nobel tras tener en cuenta que si bien el informe sobre los acuerdos europeos fue tan valioso para la Comisión como la información y las pruebas sobre los acuerdos presentadas anteriormente por UCB, llegó dos años y medio más tarde, pero, a diferencia de UCB, no cuestionó los hechos en los que la Comisión basaba sus alegaciones.

\section{Manuela Eslava Rodríguez}

Caso N. ${ }^{\circ}$ 7. Ententes: STJCE 28 junio 2005, Dansk Rørindustri A/S (C-189/02 P), Isoplus Fernwärmetechnik Vertriebsgesellschaft mbH y otros $(C$-202/02 $P$ ), KE KELIT Kunststoffwerk $\mathrm{GmbH}(C-205 / 02 P)$, LR af $1998 \mathrm{~A} / \mathrm{S}(C-206 / 02 P)$, Brugg Rohrsysteme $\mathrm{GmbH}(C-207 / 02 P)$, LR af 1998 (Deutschland) $\mathrm{GmbH}(C-208 / 02 ~ P)$ y ABB Asea Brown

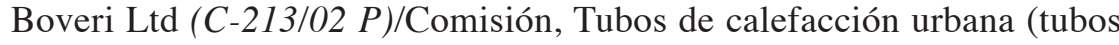
preaislados), Asuntos acumulados C-189/02 P, C-202/02 P, C-205/02 P a C-208/02 P y C-213/02 P

\section{NotA}

45. La presente sentencia es consecuencia de los recursos de casación interpuestos por Dansk Rørindustri, grupo Henss/Isoplus, KE KELIT, LR A/S, Brugg, LR GmbH y ABB solicitando la anulación de las SSTPI 20 marzo 2002, Dansk Rørindustri/Comisión (T21/99), HFB y otros/Comisión (T9/99), KE KELIT/Comisión (T17/99), LR AF 1998/Comisión (T23/99), Brugg Rohrsysteme/Comisión (T15/99), Lögstör Rör/Comisión (T16/99) y ABB Asea Brown Boveri/Comisión (T31/99) que confirman en lo sustancial la Dec.Com. 21 octubre 1998, Cártel en el mercado de los tubos preaislados (DO 1999, L 24), en la que se declaró probada la participación de diversas empresas en un cártel de dimensiones comunitarias, que nació en Dinamarca, pero cuyo objetivo a largo plazo fue desde el principio el control de todo el mercado común. Según la Comisión, este acuerdo continuado entre los productores tuvo un efecto significativo en el comercio entre los Estados miembros. 
En su motivación jurídica, el TJ aporta algunas precisiones sobre si debe tener personalidad jurídica la «entidad económica» a efectos de la imputación de la infracción de las normas de la competencia, el alcance de la participación en las reuniones y la aplicación de la Comunicación de la Comisión sobre las Directrices para el cálculo de las multas impuestas en aplicación del art. 15.2 del Rgto. 17 y del art. 65.5 TCECA (DOCE C 9, 14.01.1998) a infracciones anteriores a su publicación (Vid. A.L. CALVO CARAVACA/ J. CARRASCOSA GONZÁLEZ, Mercado único y libre competencia en la Unión Europea, Colex, Madrid, 2003, 1176-1.184).

46. Con el fin de destruir la imputación de la infracción al grupo por haber participado el titular de participaciones en el capital en unas reuniones cuyo objeto era contrario a la competencia, Henss/Isoplus alega que, conforme al art. 1 del Protocolo 22 del Acuerdo sobre el EEE, de 2 mayo 1992, el concepto de empresa a efectos de las normas sobre competencia designa cualquier entidad jurídica («Rechtssubjekt» en la versión alemana) que lleve a cabo actividades de naturaleza comercial o económica. En consecuencia, para que una infracción cometida por una empresa con personalidad jurídica propia pueda ser imputada a la sociedad holding matriz, cuando ésta controla a aquélla y constituyen una misma unidad económica, es necesario que ésta tenga, por su parte, personalidad jurídica, pero una persona física, no puede ser calificada de empresa por su condición de socio o de titular de participaciones en el capital.

El TJ recuerda que empresa en Derecho de la competencia es cualquier entidad que ejerza una actividad económica, con independencia de la naturaleza jurídica de dicha entidad y de su modo de financiación (STJCE 19 febrero 2002, Wouters y otros), y que ese concepto no exige que la unidad económica de que se trate tenga personalidad jurídica, sin que desvirtúe tal interpretación el sujeto de Derecho («Rechtssubjekt») de la versión alemana del art. 1 del Protocolo 22 del Acuerdo sobre el EEE, pues esta noción no excluye a las personas físicas y falta en las demás versiones lingüísticas, que sólo contienen el concepto de entidad. Cualquier conducta contraria a la competencia de una empresa puede imputarse a otra cuando aquélla no ha determinado de manera autónoma su comportamiento en el mercado, sino que ha aplicado, esencialmente, las instrucciones impartidas por esta última, teniendo en cuenta, en particular, los vínculos económicos y jurídicos que las unían (STJCE 16 noviembre 2000, Metsä-Serla y otros/ Comisión). Es cierto que el hecho de que el capital social de dos sociedades mercantiles distintas pertenezca a una misma persona o familia no es suficiente, por sí solo, para acreditar que existe entre esas sociedades una unidad económica que permita imputar las actuaciones de una a la otra y obligar a una a pagar una multa por la otra (STJCE octubre 2003, Aristrain/ 
Comisión), pero el TPI afirmó la existencia de una unidad económica una vez acreditado que esa persona controlaba las sociedades porque poseía (ella o su esposa) la totalidad o la práctica totalidad de las participaciones sociales, desempeñaba funciones esenciales en los órganos de dirección de dicha sociedades, representaba a las diferentes empresas en las reuniones del club de directivos, y porque el cártel atribuyó una cuota única a dichas empresas.

47. El TJ reitera, conforme a la STCE 7 enero 2004, Aalborg Portland y otros/Comisión, que acreditada la participación en tales reuniones, la empresa debe aportar los indicios apropiados para demostrar que su participación en las mismas no estaba guiada por un espíritu contrario a la competencia, probando que informó a sus competidores de que participaba con unas intenciones diferentes a las de éstos. La aprobación tácita de una iniciativa ilícita, sin distanciamiento público de su contenido o sin denuncia a las autoridades administrativas, incita a continuar con la infracción y dificulta su descubrimiento. Se trata de una participación pasiva en la infracción que conlleva la responsabilidad de la empresa en el marco de un acuerdo único incluso cuando la empresa no aplique los resultados de una reunión, a menos que se distancie públicamente de su contenido, pues a efectos del art. 81.1 TCE basta con que un acuerdo tenga por objeto impedir, restringir o falsear la competencia, independientemente de sus efectos concretos. Esta situación tiene consecuencias, no sobre la existencia de su responsabilidad, sino sobre el alcance de ésta y, por tanto, sobre el nivel de la sanción (STJCE 15 octubre 2002, Limburgse Vinyl Maatschappij y otros/ Comisión). Del mismo modo, la participación en el cártel de unas empresas dominantes capaces de adoptar represalias contra otros participantes menos potentes, no afecta a la responsabilidad de estas últimas por su participación en la medida contraria a la competencia, cuando no se distancian públicamente del contenido de las reuniones, aunque puede influir en la determinación del nivel de la sanción. La tesis contraria es inaceptable porque tendría como consecuencia establecer una diferencia en la aplicación del art. 81.1 en función del tamaño de las empresas, favoreciendo a las empresas menos potentes.

48. En los recursos se cuestiona, con apoyo en diversos principios generales del Derecho comunitario, la aplicación de las Directrices para el cálculo de las multas porque introducen un método de cálculo nuevo y habían sido publicadas con posterioridad a las infracciones y a las audiencias, última fase del procedimiento administrativo ante la Comisión. Frente al cálculo del importe en función del volumen de negocios del producto en el mercado geográfico pertinente, importe que no podía sobrepasar el importe máximo del $10 \%$ del volumen de negocios mundial de la empresa 
sin distinción de productos (art. 15.2 Reglamento 17), en las Directrices se parte de unos importes de base determinados de antemano, que reflejan la gravedad de la infracción y no guardan relación con el volumen de negocios pertinente. El importe de base puede ajustarse posteriormente mediante incrementos y reducciones en función de la duración de la infracción y de las circunstancias agravantes o atenuantes y, en una última fase, en razón de la eventual cooperación con la Comisión durante el procedimiento administrativo.

49. Del razonamiento jurídico del TJCE merecen destacarse los siguientes aspectos:

a) No infringe el principio de la confianza legítima que la Comisión eleve las multas de determinados tipos de infracción dentro de los límites indicados por el Rgto. 17. La aplicación eficaz de las normas de la competencia exige que la Comisión pueda en todo momento adaptar el nivel de las multas a las necesidades de esta política (STJCE 7 junio 1983, Musique Diffusion française y otros/Comisión). Los agentes económicos no pueden confiar legítimamente en que se mantenga una situación existente que puede ser modificada por la Comisión en el marco de su facultad de apreciación (STJCE 14 febrero 1990, Delacre y otros/Comisión). El hecho de que la Comisión haya concedido cierto porcentaje de reducción por un determinado comportamiento en la práctica seguida en sus anteriores decisiones no implica que esté obligada a conceder la misma reducción proporcional al valorar un comportamiento similar en un procedimiento administrativo posterior.

b) La Comisión, cuando adopta reglas de conducta y anuncia mediante su publicación que las aplicará en lo sucesivo a los casos contemplados en ellas, se autolimita en el ejercicio de su facultad de apreciación y no puede ya apartarse de tales reglas, so pena de verse sancionada, en su caso, por violación de los principios de igualdad de trato o la protección de la confianza legítima (STJCE 15 enero 2002, Libéros/Comisión).

c) La modificación de la política general de multas de la Comisión en materia de competencia puede afectar al principio de irretroactividad si se lleva a cabo mediante reglas de conducta tales como las Directrices que quedan englobadas en principio en el concepto de «derecho» del art. 7.1 CEDH (SSTEDH, 22 noviembre 1995, SW y CR c. Reino Unido, 15 noviembre 1996, Cantoni c. Francia y 22 junio 2000, Coëme y otros c. Bélgica). El art. 7.1 CEDH impide la aplicación retroactiva de una nueva interpretación de una norma 
que establezca una infracción, cuyo resultado no era razonablemente previsible en el momento en que se cometió la infracción, según la interpretación jurisprudencial de la disposición examinada en aquel momento.

d) La Comisión no está obligada a calcular las multas partiendo de importes basados en el volumen de negocios de las empresas implicadas. Respetando el 10\% del volumen de negocios global que fija el art. 15 del Reglamento 17, la Comisión puede tener en cuenta el volumen de negocios de la empresa a fin de valorar la gravedad de la infracción al determinar el importe de la multa, pero no debe atribuirse a dicha cifra una importancia desproporcionada en comparación con los demás criterios de apreciación. Las Directrices no se oponen a que el importe de las multas se calcule en función del volumen de negocios global de las empresas implicadas o del volumen de negocios pertinente, cuando los principios generales del Derecho comunitario y las circunstancias así lo exijan. Según el TJ, las Directrices, en cuanto obligan a tener en cuenta un gran número de factores, se ajustan mejor a los principios del Reglamento. 17 que a una supuesta práctica anterior en la que el volumen de negocios pertinente desempeñaba un papel preponderante y relativamente mecánico. Además, permiten a la Comisión ajustar la multa a cada empresa en función de la gravedad relativa de su participación en la infracción, pero no a considerar la situación financiera deficitaria de una empresa infractora porque equivaldría a procurar una ventaja competitiva injustificada a las empresas menos adaptadas a las condiciones del mercado.

\section{Manuela Eslava Rodríguez}

Caso N. ${ }^{\circ}$ 8. Ententes: STPI 18 julio 2005, Scandinavian Airlines System AB/Comisión, T-241/01

NotA

50. En esta sentencia del TPI, recaída en el asunto T-241/01, Scandinavian Airlines System $A B$ c. Comisión $C V$, sobre demanda de anulación del art. 2 de la Decisión 2001/716/CE de la Comisión, 18 julio 2001, relativa a un procedimiento de aplicación del art. $81 \mathrm{CE}$ y del art. 53 del Acuerdo EEE (asunto COMP.D.2 37.444-SAS/Maerks Air y asunto COMP.D.2 37.386Sun-Air c. SAS y Maersk Air), el demandante, Scandinavian Airlines System AB (en adelante, SAS), no cuestiona la infracción de las reglas de la competencia, sino algunos aspectos relacionados con el cálculo de la multa. 
La Comisión en la Decisión controvertida había impuesto una multa de 39.375.000€ a SAS y de 13.125.000€ a Maersk Air por haber infringido los arts. $81 \mathrm{CE}$ y 53 Acuerdo EEE al haber concluido un acuerdo global de reparto de mercados y una serie de acuerdos específicos de reparto de mercados respecto de ciertas líneas internacionales.

SAS reprocha a la Comisión haber cometido un error en la apreciación de la gravedad de la infracción, en la determinación de la duración de la infracción y en haber tomado en consideración de manera incorrecta las circunstancias atenuantes.

51. Al abordar esta importante cuestión del litigio, el TPI pone de relieve, con carácter previo, que tanto el art. 12.2 del R.3975/87 sobre las modalidades de aplicación de las reglas de la competencia a las empresas aéreas, en vigor en el momento de los hechos, como el art. 15.2 del R. 17 prevén que, en la determinación del importe de las multas, es obligado tener en cuenta la gravedad y la duración de la infracción, y que, según jurisprudencia constante, la Comisión dispone de un amplio poder de apreciación en la fijación de las multas (STPI 21 octubre 1997, Deutsche Bahn c. Comisión) que está en función de su política de la competencia (STJ 7 junio 1983, Musique Difusión française c. Comisión). Las Directrices aprobadas por la Comisión en 1998, que tienden a precisar los criterios que tendrá en cuenta en el ejercicio de esa facultad de apreciación, suponen una autolimitación en la medida que la Comisión está obligada a conformarse a las reglas indicativas que ella misma se ha impuesto (STJ 12 diciembre 1006, AIUFASS y AKT c. Comisión). Estas directrices precisan que, en la valoración de la gravedad de la infracción, debe tomarse en consideración la naturaleza propia de la infracción, su impacto concreto sobre el mercado cuando sea mensurable y la extensión del mercado geográfico concernido.

Por ello, frente al argumento de SAS de que la infracción debía haber sido calificada de «grave» por cuanto las infracciones muy graves afectarían invariablemente al conjunto, $\mathrm{o}$, al menos, a una parte muy importante del mercado común y haber causado un perjuicio efectivo a la competencia, el Tribunal, con apoyo en una constante jurisprudencia, sostiene que, aunque haya de tomarse en cuenta el tamaño del mercado geográfico concernido y el impacto en el mercado cuando sea mensurable, la naturaleza de la infracción constituye un criterio esencial para apreciar la gravedad de la infracción. En el caso de ententes sobre reparto de mercados, que figuran entre los ejemplos de ententes expresamente prohibidos por el art. 81.1 c) CE, la calificación de muy graves viene determinada por las Directrices que consideran como tales las restricciones horizontales del tipo cárteles de precios y de cuotas de reparto de mercado. Además entrañan una grave alteración del juego de la 
competencia en cuanto, al obligar a las partes a respetar mercados distintos, a menudo delimitados por las fronteras nacionales, provocan el aislamiento de estos mercados, obstaculizando el objetivo principal de la integración del mercado comunitario. De hecho la jurisprudencia suele calificar este tipo de ententes horizontales como de «particularmente graves» o de «infracciones patentes» (STPI 6 abril 1995, Tréfilunion c. Comisión, 15 septiembre 1998, European Night Services e.a.c. Comisión).

52. Continua explicando el TPI que la duración de la infracción no es criterio que permita apreciar la gravedad, sino que constituye el segundo factor, junto a la gravedad, establecido por el art. 12.2 del R. 3975/87 y por las Directrices, para fijar el montante de las multas. De hecho, ciertas infracciones han sido calificadas de muy graves a pesar de no implicar restricciones geográficas muy amplias (STPI 6 julio 2000, Volkswagen c. Comisión y STJ 18 septiembre 2003, Volkswagen c. Comisión, TPI, 21 octubre 2003, General Motors Nederland c. Comisión). El territorio de un solo Estado miembro o, incluso, una parte reducida de éste, puede ser considerado una parte sustancial del mercado común en el sentido del art. 82 CE (STJ 16 diciembre 1975, Suiker Unie. c. Comisión, 10 diciembre 1991, Merci convenzionali porto di Genova, STPI 17 diciembre 2003, Airways c. Comisión).

53. El TPI sostiene, finalmente, ante la invocación por la demandante del asunto de los «transbordadores griegos», que, en la calificación de grave o muy grave, la práctica de las decisiones anteriores de la Comisión no sirve por sí misma de marco jurídico de las multas en materia de competencia, ya que éste está determinado por el R. 17 o por los reglamentos sectoriales, como ocurre en el caso, y por las Directrices. El hecho de que la Comisión haya estimado en el pasado que las infracciones de un determinado tipo debían ser consideradas como graves no puede privarle de la posibilidad de considerarla, en un caso ulterior, como muy graves si es necesario para asegurar la aplicación de la política de la competencia, según se indicara ya en la sentencia Musique Difusión Française.

54. La fecha de inicio de la infracción es la del acuerdo de cooperación entre SAS y Maersk Air, aunque fuera aplicado con posterioridad, porque es en esa fecha cuando las partes de la entente habían perdido su autonomía. La Comisión no está obligada a determinar la duración de la infracción por la de los efectos de la misma, como pretende la demandante, porque el simple hecho de celebrar un acuerdo cuyo objeto es limitar la competencia constituye una infracción del art. 81 CE (STJ 11 julio 1989, Belasco c. Comisión). La fecha de fin de la infracción no es, como sostiene SAS, la de las inspecciones por la Comisión (15 julio 2000) al haber 
cesado todo comportamiento prohibido entonces, sino la del 15 de febrero de 2001 ya que es en esta fecha cuando SAS hace saber a Maersk Air, por carta, que no se consideraba vinculada por los acuerdos de reparto de mercado.

55. Conforme al título D de la Comunicación de cooperación, cuando una empresa coopere sin que se haya reunido las condiciones contempladas en los títulos $\mathrm{B}$ y $\mathrm{C}$, puede beneficiarse de una reducción de entre $10 \%$ y el $50 \%$ del montante de la multa que le hubiere sido impuesta en ausencia de cooperación. Este puede ser el caso (a) si ante el envío de una comunicación de cargos, la empresa suministra a la Comisión información, documentos u otros elementos de prueba que contribuyan a confirmar la existencia de la infracción, o (b) si de haber recibido la comunicación de cargos, la empresa no cuestiona los hechos sobre los que la Comisión fundamenta sus acusaciones.

En el supuesto de autos ninguna de las empresas cuestionó los hechos. Sin embargo fue Maerks Air la que propuso a los servicios de la Comisión celebrar una reunión con un representante de esta empresa, que ya la había dejado, pero que jugó un papel decisivo en las negociaciones entre ambas empresas en 1998. Con ocasión de esta reunión, Maersk Air pudo remitir a los representantes de la Comisión los documentos privados que ese representante conservaba en su domicilio y que sirvieron a la Comisión para reconstruir la evolución de las negociaciones y la extensión exacta del acuerdo. En cambio, las informaciones suministradas por SAS sólo sirvieron para confirmar lo que la Comisión ya sabía y, además, los documentos suministrados no fueron aportados voluntariamente. Por todo ello, mientras SAS tuvo una reducción de la multa del 10\%, la acordada a Maersk Air fue del $25 \%$, ya que según una jurisprudencia reiterada, la reducción de la multa en virtud de la cooperación sólo está justificada si el comportamiento de la empresa permite a la Comisión constatar la existencia de una infracción con menos dificultad, y en su caso, ponerle fin (STPI 16 noviembre 2000, Holding c. Comisión).

El TPI no tiene en cuenta las medidas adoptadas con posterioridad a la decisión porque tales medidas no afectan a la legalidad de la misma, que debe ser adoptada, obviamente, en función de los elementos de hecho y de Derecho existentes en el momento de su adopción. Por otra parte, una reducción basada en comportamientos de la empresa posteriores a la decisión sólo podría ser adoptada por el juzgador comunitario en circunstancias muy particulares, ya que una práctica semejante podría ser concebida como una incitación a cometer infracciones con la expectativa de una eventual reducción de la multa en razón de un comportamiento posterior a la decisión. 
La Comisión insta, finalmente, un aumento del montante de la multa impuesta a la demandante, prevista en el punto E de la Comunicación sobre la cooperación, por entender que, a pesar de haber obtenido SAS una reducción del $10 \%$ al no haber contestado los hechos en el procedimiento administrativo, lo hizo en la demanda de anulación. El art. 14 del Reglamento 3975/87 atribuye plena jurisdicción en el sentido del art. 229 CE sobre los recursos de anulación interpuestos contra las decisiones de la Comisión imponiendo multas. Sin embargo, en el caso, el TPI entiende que la demandante SAS no había cuestionado la materialidad de los hechos sobre los que la Comisión fundamentó los cargos.

Manuela Eslava Rodríguez

Caso N. ${ }^{\circ}$ 9. Ententes: STPI (Sala Segunda) de 27 de julio de 2005, Asuntos acumulados T-49/02 a T-51/02, Brasserie nationale SA (anteriormente Brasseries Funck-Bricher y Bofferding), Brasserie Jules Simon et Cie SCS y Brasserie Batín SNC v. Comisión de las Comunidades Europeas

\section{NotA}

56. El TPI resuelve la demanda interpuesta por Brasserie nationale SA, Brasserie Jules Simon et Cie SCS y Brasserie Batín SNC contra la Comisión de las Comunidades Europeas, en la que las demandantes reclaman la anulación de la Decisión 2002/759/CE de la Comisión, de 5 de diciembre de 2001, relativa a la aplicación del art. 81 TCE, asunto COMP/37800/F3-Fábricas de cerveza luxemburguesas (DO L 253 de 21 septiembre 2002).

La Decisión impugnada declaró contrario a las normas comunitarias de la competencia el Convenio celebrado entre cinco fabricantes de cerveza luxemburguesa, las partes ahora demandantes, por considerar que, por su objeto, restringía sensiblemente la competencia en el sector hotelero luxemburgués afectando al comercio entre Estados miembros. En opinión de la Comisión el referido convenio tenía por objeto conservar las respectivas clientelas de las partes en dicho sector y obstaculizar la penetración, en el mismo, de fabricantes de cerveza extranjeros.

Frente a la Decisión de la Comisión las demandantes fundamentan su pretensión de anulación en la violación del art. 81 TCE, de un lado, y de los arts. 15.2 del Reglamento n. ${ }^{\circ} 17$ y 253 TCE, de otro. Respecto al primer motivo, las partes alegan que la Comisión erró en la apreciación del objeto del convenio, en la delimitación de su ámbito de aplicación así como en la valoración del efecto que el mismo tenía sobre la competencia. Alegan que el único objetivo del Convenio era hacer respetar las exclusividades contractuales consentidas entre el establecimiento y el 
fabricante de cerveza, evitando así la inseguridad jurídica y los riesgos que suponía una reiterada jurisprudencia de los tribunales luxemburgueses en cuya virtud todo contrato que contenía una «cláusula de cerveza» era anulados a causa de la indeterminación del precio y de la cantidad. La necesidad de proteger la lealtad comercial llevó a los fabricantes de cerveza, en ejercicio de su libertad de actuación, a celebrar el convenio para garantizar el cumplimiento de los contratos celebrados que incluyera una «cláusula de cerveza». En definitiva, a través del convenio únicamente se prohibía contratar con un establecimiento que ya hubiera celebrado un contrato que incluyera una «cláusula de cerveza» con un competidor, sin ninguna otra prohibición cuando la relación comercial hubiera terminado. En ningún caso el convenio tiene por objeto, como deduce la Comisión, el reparto de mercado. Pero tampoco es su objeto obstaculizar la penetración en el sector afectado de fabricantes de cerveza extranjeros. No sólo porque éstos también podrían haber participado en el convenio, sino también porque la única intención de las partes era hacer respetar las «cláusulas de cervezas» entre todos los fabricantes de cervezas.

De otra parte, consideran los demandantes, que la Comisión no apreció correctamente el contexto en el que el convenio celebrado se enmarca. Se trata de un sector caracterizado por su dinamismo, en el que los productores extranjeros gozan de una elevada cuota de mercado y en el que existe un importante número de establecimientos que no están vinculados a las empresas participantes en el convenio (cdo. 66). Teniendo en cuenta este contexto, el convenio no afecta negativamente al mercado y, por tanto, no tiene efectos restrictivos en el sentido del art. 81 TCE.

57. En su sentencia, de fecha 24 julio 2005, considera el TPI, con base en el art. 4 del Convenio celebrado entre las demandantes, que a través del mismo las partes se prohibían recíprocamente y se comprometían a prohibir a sus depositarios «toda venta de cerveza». Se trata de un acuerdo horizontal que pretende ser subsumido en el ámbito de aplicación del Reglamento 1984/83 relativo a la exención de categorías de acuerdos horizontales. Sin embargo, a tenor del precepto referido, el convenio va más allá del art. 7.1 de la disposición comunitaria que permite únicamente determinadas restricciones de la competencia en la relación, vertical, entre revendedor y proveedor y que, por tanto, no se refiere a los acuerdos horizontales como el presente. Aunque el convenio tenga como finalidad, a tenor de las alegaciones de las partes, garantizar las exclusividades contractualmente admitidas entre establecimiento y fabricante así como proteger la lealtad comercial, lo cierto es que, como acertadamente consideró la Comisión, entre su objeto se encuentra el reparto de clientela. La presencia de aquel 
interés legítimo no desvirtúa la restricción de la competencia que se deriva de un acuerdo cuyo objeto es, por su propia naturaleza, restrictivo de la competencia.

Al tenor literal del art. 4 del convenio celebrado se añade, para acreditar la voluntad de las partes en la conclusión de acuerdo de reparto de clientela referido a toda venta de cerveza, los acuerdos en orden a la interpretación del término «cláusula de cerveza», así como otras manifestaciones de las partes. En este punto, siguiendo una reiterada jurisprudencia, el TPI afirma que, con independencia de la forma del acuerdo, lo decisivo a efectos de considerar un acuerdo en el sentido del art. 81 TCE es la expresión de una voluntad común de las partes implicadas en comportarse de determinada manera en el mercado. Debe acreditarse la existencia de un acuerdo de voluntades independientemente de la forma en el que el mismo sea expresado (SSTJCE de 15 julio 1970, ACF Chemiefarma/Comisión, 41/69, Rec. p. 661, y de 29 octubre 1980, Van Landewyck y otros/Comisión, asuntos acumulados 209/78 a 215/78 y 218/78, Rec. p. 3125; STPI 26 octubre 2000, Bayer/Comisión, T-41/96, Rec. p. II-3383). La concordancia de voluntades ha sido correctamente valorada por la Comisión a tenor del acta de la reunión de la FBL así como a tenor de las declaraciones de algunas de las partes implicadas que reconocen la aplicación del convenio a relaciones en las que no existe cláusula de cerveza ni contrato de suministro.

58. Acreditado el reparto de clientela como uno de los objetos del convenio, el segundo objeto de éste, según la Comisión, es obstaculizar la entrada en el sector hotelero luxemburgués de fabricantes extranjeros. El texto del art. 11 del convenio sirve de fundamento al tribunal para considerar acertada la decisión de la Comisión en este punto. A través del precepto se prevé la posibilidad de excluir a una parte en caso de ser adquirida por una sociedad extranjera o de cooperación con un fabricante extranjero. Asimismo, las partes se reservan entre sí la prioridad para captar y celebrar contratos de suministros con establecimientos vinculados a una de ellas y que se propongan contratar con fabricantes extranjeros. En la Declaración de intenciones, también se acredita el objeto restrictivo, al no proteger al fabricante extranjero cuando un cliente luxemburgués se propone abastecerse de un fabricante de cerveza luxemburgués, refiriéndose únicamente al fabricante extranjero que desea suministrar a un establecimiento luxemburgués. En el análisis del objeto del convenio, no se pueden tener en cuenta los elementos que alegan las partes a la hora de definir el contexto en el que aquél se desarrolla (dinamismo del sector en cuotas de mercado, la apertura y amplitud a las importaciones y la existencia de un elevado número de establecimientos no vinculados a las partes) pues no afectan al objeto del convenio sino que están relacionados con la determinación de sus efectos (cdo 108). 
59. Acreditada la existencia de un acuerdo que tiene por objeto el reparto de clientela y obstaculizar la penetración en el sector hotelero luxemburgués de fabricantes de cervezas extranjeros, su efecto restrictivo de la competencia se deriva de la propia naturaleza del acto. No es necesario, en este sentido delimitar el mercado de referencia para decidir su afectación al comercio entre los Estados miembros, exigencia que únicamente se establece cuando sin delimitar dicho mercado de referencia no es posible decidir si determinado acuerdo, decisión de empresas o práctica concertada afecta al comercio entre los Estados miembros en el sentido del art. 81 TCE. La expresión «por objeto o por efecto» que el precepto utiliza deja clara la relación de alternatividad entre ambos supuestos. De este modo, verificado el objeto anticompetitivo del convenio, como ha ocurrido en el presente asunto, no es necesario probar sus efectos. La valoración de estos últimos no se exige, para la aplicación del art. $81 \mathrm{TCE}$, cuando resulte del propio objeto del acuerdo (Comunicación de la Comisión-Directrices relativas a la aplicación del apartado 3 del art. 81 del Tratado (DO C 101 de 27 abril 2004) y, entre otras, la STJCE 8 julio 1999, Comisión/Anic Partecipazioni, Rec. I- 4125, C-49/92P).

60. El segundo motivo alegado se refería a la violación de los arts. 15.2 del Reglamento n. ${ }^{\circ} 17$ y 253 TCE, considerando que la infracción no fue deliberadamente cometida, que la comisión erró en la apreciación de la gravedad y duración de la infracción y en aplicación de las Directrices en materia de circunstancias atenuantes.

Delimitado el objeto del convenio celebrado entre fabricantes de cerveza luxemburguesa en los términos expuestos, las partes no pueden ignorar la restricción que el acuerdo produce en la competencia, sin que sea necesario que las empresas participantes tengan conciencia de infringir las normas. Basta con no ignorar que el objeto de la conducta que se le imputa era restrictivo de la competencia, sin que, por tanto, puedan admitirse las alegaciones de las demandantes relativas a que no tuvieron conciencia de que el convenio restringía el comercio interestatal, que por su dimensiones se puede admitir su ignorancia del Derecho y que no pretendieron obstaculizar a fabricantes de cerveza extranjeros ni creyeron que el objetivo de preservar la competencia nacional pudiera ser calificado como anticompetitivo. De otra parte, el objeto del convenio es calificado como una infracción muy grave atendiendo a su naturaleza, repercusiones concretas sobre el mercado y dimensión del mercado geográfico afectado. Analizados todos estos factores y teniendo en cuenta que el reparto de mercado, objeto del convenio celebrado, constituye una de las conductas consideradas infracciones muy graves, una de las restricciones «más dañinas» porque interfieren directamente con el resultado del juego de la competencia (Co- 
municación de la Comisión-Directrices sobre la aplicabilidad del art. 81 del Tratado a los acuerdos de cooperación horizontal ( $D O$ C 3 de 6 enero 2001)), el TPI confirma la Decisión impugnada desestimando la demanda interpuesta por los fabricantes de cerveza luxemburgueses.

Mercedes Sabido Rodríguez.

Caso N. ${ }^{\circ}$ 10. Ententes: Comunicación publicada de conformidad con el artículo 27, apartado 4, del Reglamento (CE) n. ${ }^{\circ} 1 / 2003$ del Consejo, en los asuntos COMP/C2/3912-BUMA y COMP/C2/39151-SABAM (Acuerdo de Santiago-COMP/C2/38126, DO C 200 de 17 agosto 2005, pp. 11-12)

Nota

61. De nuevo se evidencian las dificultades que suscita el carácter estrictamente territorial de los derechos de autor y las posibilidades que ofrecen las nuevas tecnologías de utilizar las obras protegidas más allá de las fronteras nacionales. Junto a esta cuestión, en la actualidad el debate se centra en la gestión de los derechos de autor en el nuevo entorno digital. Las entidades encargadas de gestionar estos derechos en cada Estado buscan mecanismos que garanticen la protección y permitan el control de las utilizaciones o explotaciones de las obras protegidas. En este marco se han celebrado por distintas entidades de gestión de derechos de autor varios acuerdos, en función de los derechos gestionados. Una de las novedades introducidas por estos acuerdos es la creación de un nuevo tipo de licencias, las licencias multirrepertorio y multiterritorio. A través de ellas, una entidad nacional puede licenciar la utilización de todas las obras del repertorio administrado por las entidades que lo celebran en varios Estados.

62. En este marco, y con esta finalidad, fueron elaborados el Acuerdo de Santiago de 2000 y el Acuerdo de Barcelona de 2001. El primero de ellos, el Acuerdo de Santiago, adoptado por la Confederación Internacional de Autores y Compositores (CISAC), tiene su origen en la necesidad de articular nuevos mecanismos que permitan adecuar la utilización de las obras musicales a las posibilidades que ofrecen las nuevas tecnologías, como Internet. Para ello, a través de este Acuerdo, se instaura un sistema de ventanilla única para la concesión de autorizaciones de difusión o descarga de música en la Red. Se elabora una nueva categoría de licencias para los derechos de ejecución pública de obras musicales, las licencias multirrepertorios, que comprenden los repertorios administrados por las sociedades de gestión colectiva que han aplicado este tipo de licencias, y se incluyen un contrato estándar. En cuanto al Acuerdo de Barcelona, fue celebrado por Bureau International des Sociétés gérant les droits d'enregistrement et de 
reproduction mécanique (BIEM), relativo a los derechos de reproducción mecánica. A través de este último acuerdo también se elaboran contratos estándar relativos a licencias globales de reproducción mecánica de obras en Internet. Licencias otorgadas por entidades de gestión nacionales cuya vigencia no se limita al territorio del Estado en el que se conceden.

En definitiva, a través de este tipo de acuerdos se tiende a la creación de una gestión colectiva en Internet de los derechos protegidos. Sin duda, estos mecanismos pueden favorecer y facilitar la utilización de las obras protegidas y garantizaran los derechos de los titulares. Incluso, a través de ellos se puede ampliar la oferta de servicios, algo que beneficiaría tanto al titular del derecho como a los usuarios. Sin embargo, en tanto que acuerdos entre empresas susceptibles de afectar al comercio entre los Estados miembros, los acuerdos celebrados entre las entidades de gestión de derechos de autor deben ser analizados a la luz de las normas de la competencia. En este marco se encuadra la Comunicación de la Comisión de 17 de agosto de 2005, en la que se ponen de relieve las cuestiones que suscitan, en relación con el Derecho de la competencia, algunos acuerdos celebrados entre distintas entidades de gestión de derechos de autor.

63. El 17 de abril de 2001 fueron notificados a la Comisión acuerdos bilaterales celebrados entre distintas entidades de gestión de derechos de autor de los Estados miembros, BUMA, Gesellschaft für musikalische Aufführungs-und mechanische Vervielfältigungsrechte (GEMA), The Performing Rigth Society Ltd. (PRS) y Société des Auteurs, Compositeurs et Editeurs de Musique (SACEM) (DO C 145 de 17 mayo 2001). Con posterioridad, se unen a la notificación otras sociedades de gestión de derechos de autor de otros Estados miembros y de Estados parte del EEE (AKM de Austria, IMRO de Irlanda, SABAM de Bélgica, STIM de Suecia, TEOSTO de Finlandia, KODA de Dinamarca, STEF de Islandia, TONO de Noruega, AEPI de Grecia, SIAE de Italia, SGAE de España y SUISA de Suiza).

Los acuerdos notificados se ajustan al acuerdo estándar elaborado en el marco del Acuerdo de Santiago, a través del cual se permiten las licencias para ejecución pública de obras musicales en Internet. Siguiendo las pautas de este último, los nuevos acuerdos introducen algunas modificaciones en relación con los acuerdos recíprocos y bilaterales anteriormente celebrados por las sociedades notificantes. En su virtud se autoriza a cada parte a conceder licencias no exclusivas para la ejecución pública en línea de obras musicales del repertorio de la otra parte a escala internacional. Asimismo, incluyen la denominada cláusula de residencia económica, a través de la cual los usuarios sólo pueden obtener licencias para la difusión de música en línea en las sociedades de gestión de sus países de residencia. 
64. A la vista de los acuerdos notificados, la Comisión analiza su adecuación a las normas de la competencia, emitiendo, con fecha 29 abril 2004, un pliego de cargo dirigido a las dieciséis entidades notificantes en el que expone ciertas dudas que suscitan algunas cláusulas contenidas en los acuerdos notificados. En concreto, la denominada cláusula de residencia económica y la cláusula de la nación más favorecida (IP/04/586 de 3 mayo 2004).

65. A tenor de la primera, la cláusula de residencia económica, las sociedades de gestión de derechos de autor nacionales gozan de exclusividad territorial a la hora de conceder licencias para la distribución de productos musicales. Esto es, para conceder las licencias multirrepertorio, la única sociedad con autoridad es la del país donde el proveedor del contenido tiene su sede real y económica. De este modo, la cláusula de residencia económica impone la obligación a los consumidores de solicitar estas licencias a la sociedad de gestión del lugar de su residencia, limitando sus posibilidades de elegir el prestador de servicios. Pero, además, a través de este tipo de cláusulas las empresas participantes en el Acuerdo eliminan la competencia entre ellas. No sólo se refuerza su posición dominante en el mercado sino que mediante la cláusula de residencia económica se está produciendo un reparto del mercado de productos musicales. La posición dominante en el mercado de obras protegidas de la que tradicionalmente gozan las entidades de gestión de derechos de autor se ve reforzada por la obligación impuesta al usuario de contratar con la entidad de su país de residencia, eliminándose de este modo la competencia entre estas entidades. A través de los acuerdos notificados a cada entidad nacional de gestión de derechos de autor se le concede la exclusividad absoluta en su territorio para conceder licencias multirrepertorio. Este tipo de cláusulas choca con la creación de un mercado único europeo que exige una mayor libertad para los usuarios en la elección de los prestatarios de servicios. La exclusividad territorial que otorgan los acuerdos no sólo limita esa libertad sino que, además, supone un reparto de mercados entre las empresas participantes restringiendo la competencia entre las mismas y, en consecuencia, resultan contrarias al art. 81 TCE.

66. Por lo que hace a la cláusula de la nación más favorecida, prevista en la sección VII del Acuerdo de Santiago, en opinión de la Comisión, a través de ella se refuerza la exclusividad territorial de las sociedades de gestión de derechos de autor. La limitación multilateral y su garantía, también multilateral, conllevarán la uniformización de las condiciones para la concesión de las licencias en el EEE. No sólo se elimina la competencia entre empresas competidoras sino que, además, se impide la evolución del mercado «cristalizando la exclusividad de que disfruta cada una de las sociedades participantes» (cdo. 7 Comunicación de 17 agosto 2005). 
67. Como consecuencia de las consideraciones efectuadas por la Comisión, las entidades de gestión de derechos de autor de los Países Bajos (BUMA) y de Bélgica (SABAM) responden al pliego de cargos comunicando a la Comisión su voluntad de no incluir en sus acuerdos bilaterales cláusulas de residencia económica que, como las contenidas en el Acuerdo de Santiago y calificadas como restrictivas en el pliego de cargos, impliquen una exclusividad territorial. En concreto, mediante sus escritos de fecha 25 de abril y 10 de mayo de 2005, se comprometen, respectivamente, a no participar en acuerdos de licencia de explotación pública de los derechos de utilización online que contengan una cláusula de residencia económica, similar a la recogida en la sección II del Acuerdo de Santiago, ni la cláusula de la nación más favorecida en los términos previstos en la sección VII del referido Acuerdo. La Comisión, a la vista de estos compromisos comunica la posibilidad de que los acuerdos referidos a ambas sociedades puedan ser declarados conforme a las normas de la competencia durante un período de tres años.

68. Es necesario adaptar la ordenación jurídica de la gestión de los derechos de autor a las nuevas tecnologías y garantizar la tutela de estos derechos en el entorno que ofrecen las mismas. En esta línea las instituciones comunitarias han adoptado distintas iniciativas (Vid., «La gestión de los derechos de autor y derechos afines en el mercado interior», Comunicación de la Comisión al Consejo, al Parlamento y al Comité Económico y Social, COM (2004) 261 final; Recomendación 2005/737/ CE, de la Comisión, de 18 octubre 2005, relativa a la gestión colectiva transfronteriza de los derechos de autor y derechos afines en el ámbito de los servicios legales de música en línea, DO L 276 de 21 octubre 2005). Sin embargo, los mecanismos que se elaboren deben equilibrar los intereses, públicos y privados, que subyacen a la ordenación jurídica de los derechos de autor con los del mercado. Desde esta perspectiva, no está justificada la exclusividad territorial creada por los acuerdos notificados. Infringen la prohibición de prácticas restrictivas recogida en las normas comunitarias y, a diferencia de lo que ocurrió en la Decisión Simulcasting (Dec.Com.8 octubre 2002, IFPI «Emisión simultánea», DO L 107 de 30 abril 2003), tales acuerdos no pueden ser excepcionados con base en el art. 81.3 TCE. En efecto, en el referido asunto, se establece un sistema paneuropeo de concesión de licencias, sin exclusividad territorial, a través del cual las sociedades de difusión televisiva y radiofónica pueden obtener una licencia en cada una de las sociedades de gestión de derechos de autor implantados en el EEE con el fin de transmitir obras musicales en Internet. Se garantiza la tutela de los derechos y, a la vez, la ausencia de exclusividad territorial permite al consumidor, usuario, elegir la sociedad más eficaz para la concesión de licencias, manteniéndose el nivel de competencia exigido.

Mercedes Sabido Rodríguez 
Caso N. ${ }^{\circ}$ 11. Ententes: STPI 15 septiembre 2005, DaimlerChrysler AG/ Comisión, $T-325 / 01$

NotA

69. Esta sentencia del TPI aborda el interesante tema de las relaciones entre una sociedad y su representante comercial o entre un comitente y su comisionista a los efectos del art. 81.1 CE. El litigio entre las partes trae causa del sistema de distribución de turismos de la marca Mercedes-Benz (en adelante, MB). En Alemania, la distribución se lleva a cabo a través de una red que incluye sucursales pertenecientes al grupo, agentes con estatuto de agentes comerciales (art. 84.1 C. de c. alemán), que actúan como intermediarios, y comisionistas. La red de distribución belga consta de un importador, MBBel, filial al $100 \%$ de Daimler-Benz AG, a su vez filial al $100 \%$ de la demandante, y que vende vehículos nuevos por mediación de dos sucursales, de concesionarios y de agentes o talleres que ejercen también de intermediarios en la venta de vehículos nuevos. En España, la distribución de turismos se realiza a través de tres sucursales de MBE y por medio de concesionarios. Algunos de los agentes o talleres oficiales no venden vehículos, sino que sólo actúan como intermediarios en la venta. MBE es filial al $100 \%$ del holding nacional Daimler-Benz España, S.A., que a su vez era filial al 99,88\% de Daimler-Benz AG. Desde finales de 1998, este holding es filial al $100 \%$ de DaimlerChrysler AG.

La Comisión declara aplicable el art. 81.1 CE a los contratos entre MB y los agentes alemanes en la misma medida que a los contratos concluidos con un agente comercial, debiendo evaluarse las restricciones impuestas a aquéllos del mismo modo que si se tratara de comerciantes por cuenta propia. La demandante difiere del análisis de la Comisión sobre el estatus jurídico de los agentes alemanes de MB.

70. Como recuerda el Tribunal, para que exista acuerdo del art. 81.1 CE es necesaria una concordancia de voluntades entre, al menos, dos partes (STPI 26 octubre 2000, Bayer/Comisión, STJ 6 enero 2004, BAI y Comisión/Bayer). Los comportamientos unilaterales de las empresas son ajenos a la prohibición del art. 81.1 (SSTJ 25 octubre 1983, AEG/Comisión, 17 septiembre 1985, Ford/Comisión, STPI 7 julio 1994, Dunlop Slazenger/ Comisión), haciendo referencia el concepto de empresa a una unidad económica aunque esté constituida por varias personas físicas o jurídicas (STJ 12 julio 1984, Hydroterm, STPI 29 junio 2000, DSG/Comisión). Lo decisivo es la unidad de su comportamiento en el mercado, lo que exige determinar si dos sociedades jurídicamente separadas constituyen una misma y única empresa o entidad económica que presenta un comportamiento único en el mercado (STJ 14 julio 1972, ICI/Comisión). 
Esta situación no se limita a las relaciones entre matriz y filial, sino que incluye asimismo las relaciones entre una sociedad y su representante comercial o entre un comitente y su comisionista. $\mathrm{Al}$ aplicar el art. $81 \mathrm{CE}$ es igualmente decisivo determinar si un comitente y su intermediario o representante comercial forman una unidad económica y éste es un órgano auxiliar integrado en la empresa de aquél. Así si un intermediario ejerce una actividad en beneficio de su comitente, puede en principio considerarse como órgano auxiliar integrado en la empresa de éste, obligado a atenerse a las instrucciones del comitente y formando así con dicha empresa, a semejanza del empleado comercial, una unidad económica (STJ 16 diciembre 1975, Suiker Unie y otros/Comisión). No ocurre lo mismo cuando los acuerdos entre el comitente y sus agentes atribuyen funciones que económicamente se asemejan a las de un comerciante independiente, asumiendo el intermediario los riesgos financieros vinculados a la venta o a la ejecución de los contratos celebrados con terceros. Los agentes pierden su condición de operadores económicos independientes cuando no soportan ninguno de los riesgos resultantes de los contratos negociados por el comitente y operan como auxiliares integrados en su empresa (STJ 24 octubre 1995, Volkswagen y VAG Leasing). En tal caso, no pueden ser aplicables las prohibiciones del art. 81.1 a las relaciones entre el agente y su comitente con el que forma una unidad económica.

71. En el caso enjuiciado por el TPI, las relaciones entre MB y sus agentes comerciales en Alemania se regían por un contrato de agencia tipo y por el C. de c. alemán. Conforme al contrato, es MB, y no sus agentes alemanes, quien vende directamente a los clientes automóviles nuevos MB en Alemania, prohibiéndose a los agentes venderlos en nombre propio y por su cuenta. Su función se limita a transmitir a MB, para su aprobación y ejecución, las solicitudes de pedidos de los clientes potenciales, no entrando en vigor el contrato hasta que MB acepta el pedido. En la negociación del contrato de compraventa con un cliente, el agente tampoco tiene autoridad en cuanto al precio del vehículo ni está habilitado para conceder descuentos por cuenta de MB sin el consentimiento de ésta, si bien puede concederlos con cargo a su propia comisión sin tal consentimiento. El agente alemán, a diferencia de los concesionarios MB de Bélgica o España, no compra vehículos nuevos a ésta para revenderlos a los clientes ni está obligado a disponer de un stock de vehículos nuevos, por lo que no puede ser asimilado a un distribuidor de automóviles que obtiene del fabricante, en concepto de retribución, un margen que no sólo destina a la financiación de su negocio de venta de vehículos nuevos, sino sobre todo a la aplicación de descuentos a los compradores.

A la vista de los términos del contrato de agencia que vincula a MB y sus agentes alemanes, el TPI considera, en lo que respecta al mercado del comercio minorista de turismos Mercedes, que, siendo MB quien determi- 
na las condiciones de cada venta de vehículos, en particular el precio de venta, y quien asume los principales riesgos relativos a dicha actividad, los agentes alemanes deben asimilarse a empleados y considerarse integrados en la empresa con la que forman una unidad económica. En consecuencia, que el agente alemán de $\mathrm{MB}$, cuando actúa en el mercado minorista de venta de vehículos Mercedes, no constituye por sí mismo una empresa en el sentido del art. 81.1, aunque realicen actividades en otros mercados distintos del examinado que impliquen ciertos riesgos.

Para el TPI, contrariamente a lo afirmado por la Comisión, el grado de integración de los distribuidores belgas y españoles de MB no es equivalente al de sus agentes alemanes a tenor de los contratos tipo de distribución de MB en Bélgica y en España. A diferencia del contrato de agencia alemán, éstos prevén que el concesionario es responsable de la distribución de los vehículos, de la negociación de las ventas, compra sus productos y los vende a sus clientes en su nombre y por su cuenta y riesgo. Disponen también que MB y sus concesionarios mantienen su independencia. El concesionario no es un agente ni un mandatario de MB y las partes no pueden obligarse recíprocamente. Además, debe mantener un stock permanente de vehículos nuevos - además de los denominados vehículos de demostración - destinados a ser expuestos en sus establecimientos y a ser entregados a sus clientes.

Tales elementos, según el TPI, subrayan la distinción entre el papel del agente alemán que está integrado en la empresa de su comitente MB y el del distribuidor independiente en Bélgica y en España. En el comercio minorista de turismos Mercedes, el distribuidor independiente puede influir en las condiciones en que se realizan las ventas, puesto que él es el vendedor, quien asume el riesgo principal del precio del vehículo y quien guarda los vehículos en stock. Ese margen de negociación que tiene el distribuidor entre el fabricante y el cliente es el que expone al distribuidor al riesgo de que se aplique el art. $81 \mathrm{CE}$ a su relación con el fabricante. En atención a las diferencias entre el estatuto de los agentes alemanes y los distribuidores belgas y españoles, el TPI estima no acreditada la existencia de un acuerdo entre empresas en el sentido del art. 81.1 CE.

72. El TPI aborda también otro tema de interés. Se trataba de saber si, como había declarado la Comisión en la Decisión controvertida, las restricciones de suministro a empresas externas de arrendamiento financiero hasta que no haya un tomador concreto del arrendamiento financiero, previstas en los contratos alemanes y españoles, tenían por objeto limitar la competencia en Alemania y España entre las empresas de leasing del grupo MB y las empresas de leasing externas.

En la Decisión controvertida, la Comisión no distingue entre el mercado alemán y el mercado español en lo que se refiere a estas restricciones, 
presumiendo que el art. 4, d), del contrato de concesión español ha implicado las mismas restricciones de la competencia que el art. 2, 1, d), del contrato que vincula a los agentes alemanes. El problema residía en que, a diferencia de lo que ocurre en Alemania, los contratos de arrendamiento financiero celebrados en España están sujetos por la Ley 26/1988 (Disp. Adic. Séptima) a ciertos requisitos: a) deben tener una duración mínima de dos años si se trata de bienes muebles, incluidos los vehículos automóviles; b) deben incluir necesariamente una opción de compra a su vencimiento en favor del usuario; c) los bienes muebles, incluidos los vehículos automóviles, que son objeto de los contratos de arrendamiento financiero son adquiridos con esa finalidad por la entidad de arrendamiento financiero según las especificaciones del usuario.

De la Ley española se deduce, por tanto, que toda entidad de arrendamiento financiero española tiene ya un tomador identificado del contrato de arrendamiento financiero en el momento de la adquisición del vehículo. El TPI considera, en consecuencia, erróneo que las cláusulas que figuran en los contratos alemán y español produzcan efecto idéntico. Si la ley española exige que toda empresa de arrendamiento financiero tenga un usuario identificado en el momento de la adquisición del vehículo, las restricciones mencionadas resultan de la citada Ley, con independencia del art. 4. d) del contrato de concesión español. En otros términos, por el sólo efecto de esta legislación, las sociedades externas al grupo MB se encuentran en la misma situación que las que pertenecen a dicho grupo, por lo que tales restricciones al suministro de las empresas de leasing en España no constituyen restricciones de la competencia en el sentido del art. 81.1. Anula, en consecuencia, el art. 1, tercer guión, de la Decisión controvertida en la medida en que se refiere a la supuesta infracción cometida en España.

Manuela Eslava Rodríguez

\section{Abuso de posición dominante}

Caso N. ${ }^{\circ}$ 12. Abuso de posición dominante: Dec.Com. 24 marzo 2004, Microsoft Europe, COMP/C-3/37.792: Noción de abuso de posición dominante (la tensión entre el Derecho de la competencia y el Derecho de la propiedad intelectual)

NotA

73. En la resolución objeto de la presente Nota la Comisión, tras una amplia y exhaustiva investigación de más de 5 años, adopta la decisión de declarar que la empresa estadounidense de software Microsoft Corporation 
ha infringido las normas de competencia comunitarias al abusar de su posición de dominio (Microsoft ostenta una posición de quasi monopolio puesto que sus sistemas operativos equipan a más del $95 \%$ de los ordenadores personales a nivel mundial).

74. Los hechos que motivan la Decisión tienen su origen en la denuncia que Sun Microsystems interpuso en 1998 por la que informaba que Microsoft se había negado a suministrar la información sobre interfaces que necesitaba para desarrollar productos que pudieran dialogar correctamente con Windows y poder así competir en igualdad de condiciones en el mercado de sistemas operativos para servidores de grupos de trabajo. La investigación llevada a cabo por la Comisión demostró que Sun no era la única empresa a la que se le había denegado esta información. Por otra parte, en el año 2000 la Comisión, por iniciativa propia, amplió su investigación para analizar los efectos de la vinculación de Windows Media Player de Microsoft (en lo sucesivo, «WMP») con su sistema operativo para PC Windows 2000. Esta segunda fase de la investigación llevó a la conclusión de que la omnipresencia de la que se beneficiaba WMP como resultado de su vinculación al sistema operativo Windows PC reducía artificialmente los incentivos de las empresas de contenidos musicales, cinematográficos y multimedia, así como de quienes desarrollaban software y suministraban contenidos.

A la vista de lo anterior no es difícil deducir que la infracción que se le imputa a la denunciada está directamente relacionada con la restricción deliberada de la interoperabilidad entre los PC Windows y los servidores de grupos de trabajo de sus competidores, y con la vinculación su WMP, sector en el que había competencia, a su omnipresente sistema operativo. Y ello porque con esta conducta Microsoft consiguió alcanzar una posición de dominio en el mercado de sistemas operativos para grupos de trabajo (que constituyen el núcleo de las redes informáticas de las empresas) y debilitó considerablemente la competencia en el mercado de reproductores multimedia. Con ello, ha frenado la innovación tecnológica y perjudicado el proceso de competencia y a los consumidores quienes, en definitiva, tienen menos capacidad de elección y se enfrentan a precios más elevados.

75. Como consecuencia de estas prácticas, la Comisión impuso a Microsoft una multa de 497.196,304 euros. Además, con el fin de restablecer las condiciones de competencia leal, impuso las siguientes medidas correctoras: a) Por lo que a la interoperabilidad respecta, se exigió a Microsoft que en el plazo de 120 días divulgara la documentación completa y precisa sobre los interfaces, de forma que permitiera a los servidores para grupos de trabajo competidores garantizar una interoperabilidad total con los PC y servidores Windows. Además, obligó a Microsoft a actualizar la informa- 
ción que cada vez que ponga en el mercado nuevas versiones de los correspondientes productos; En relación con la vinculación, se exigió a Microsoft a que en el plazo de 90 días ofreciera a los fabricantes de PC la alternativa de adquirir una versión de su sistema operativo sin WMP.

76. La presente decisión aborda el conflictivo problema de la interrelación entre el Derecho europeo de la competencia y el Derecho de la propiedad intelectual, problemática que va cobrado una importancia cada vez mayor en los últimos años. Piénsese que, como medida correctiva, la Comisión obliga a una empresa en posición dominante a conceder licencias sobre sus derechos de propiedad intelectual sin que la denunciada pueda alegar sus derechos de propiedad intelectual como justificación objetiva para negarse a proporcionar la tecnología exigida.

77. Los primeros asuntos en que se planteó esta cuestión fueron Volvo contra Veng (STJCE de 5 de octubre de 1988, Asunto 238/87, Rec. 1988, p. 6211 y ss.) y CICRA contra Renault (STJCE de 5 de octubre de 1988, Asunto 53/87, Rec.1988, pp. 6039 y ss.). En ellos, los fabricantes de automóviles que eran titulares de un derecho de propiedad intelectual sobre las piezas para carrocerías de sus vehículos se negaron a conceder licencias a fabricantes independientes de piezas de recambio para imitar sus modelos. Esta práctica recibió el visto bueno del TJCE, quien dictaminó que la facultad del titular de un derecho intelectual de impedir usos no autorizados de los mismos constituía la esencia misma de este derecho. No obstante, en esta resolución el Tribunal dejaba las puertas abiertas para determinar cuándo el ejercicio de los mismos podía constituir un comportamiento abusivo (apartado 9 de la sentencia Volvo contra Veng).

78. Posteriormente, en la sentencia Magill (STJCE de 6 de abril de 1995, RTE e ITP/Comisión, asuntos acumulados C-241/91 P y C-242/91 P, Rec.1995, pp. 743 y ss.) el TJCE precisó las circunstancias excepcionales que debían concurrir para calificar la negativa a conceder la licencia como un comportamiento abusivo. A saber: a) Que la negativa obstaculice la aparición de un producto nuevo en el que exista una demanda potencial por parte de los consumidores; b) Que carezca de justificación; c) Que pueda excluir toda competencia en un mercado derivado. Concretamente, en la sentencia Magill, en la que el comportamiento reprochado a una de las cadenas de televisión dominante consistía en ampararse en el derecho de autor conferido por la legislación nacional sobre las listas de sus programas para impedir que otra empresa publicara semanalmente, con algunos comentarios, informaciones relativas a esos programas, concurrían las tres circunstancias: No existía ningún producto sustitutivo real o potencial de una guía semanal de televisión con información sobre los programas de la 
semana siguiente. Sin embargó, sí existía una demanda constante por parte de los consumidores. De hecho, la única posibilidad que se le ofrecía al telespectador que deseaba informarse de la oferta televisiva de la semana siguiente era comprar las guías semanales que editaba cada cadena; no existía justificación objetiva para la negativa; $y$, finalmente, la conducta de las cadenas, reservándose para ellas el mercado secundario de las guías de televisión, excluía cualquier competencia en el mercado puesto que se negaba el acceso a información de carácter básico y necesario.

En cualquier caso, esta sentencia ha sido objeto de numerosas críticas puesto que genera muchas dudas sobre la extensión del contenido de los derechos de propiedad intelectual, máxime si tenemos en cuenta que una interpretación amplia y flexible de lo que el Tribunal denomina «circunstancias excepcionales» podría llevar a identificar la tenencia de un derecho de propiedad intelectual con el abuso de una posición de dominio (en este sentido, F. HERNÁNDEZ RodRíGUEZ: «Derechos de autor y abuso de posición dominante en la Unión Europea», Anuario de Derecho Internacional, 1994-1995, p. 338; M.A. PEÑA: «La doctrina de los recursos esenciales en la Unión Europea y en España», Anuario de la Competencia, 2001, p. 430; M. WaelbroecK/A. Frignani: Derecho europeo de la competencia, Bosch, Barcelona, 1998, p. 849; R. WISH: Competition Law, 4. ${ }^{\text {a }}$ ed., Butterworths, 2001, p. 700).

79. Con carácter más reciente, en la sentencia dictada en el asunto $I M S$ Health contra NDC Health (STJCE de 29 de abril de 2004, IMS Healh GMBH \& Co. OHG/NDC GMBH \& Co. OHG, asunto C-418/01, Rec. 2004, pp. 5039 y ss.), el TJCE vuelve a recordar que el derecho exclusivo de reproducción forma parte de las prerrogativas del titular de derechos de la propiedad intelectual pero que la negativa a conceder una licencia por parte de una empresa que ostenta una posición dominante podría constituir un abuso en el sentido del artículo 82 en circunstancias excepcionales. Y, al responder a las cuestiones prejudiciales que allí se le plantean, perfila el alcance y contenido de las mismas. Así, en relación con el requisito relativo a la aparición de un producto nuevo, el TJCE afirma que la negativa a la concesión de la licencia «sólo puede considerarse abusiva en el caso de que la empresa que ha solicitado la licencia no pretenda limitarse, esencialmente, a reproducir productos o servicios que ya ofrece el mercado derivado del titular del derecho de propiedad intelectual, sino que tenga la intención de ofrecer productos o servicios nuevos que el titular no ofrece y respecto a los cuales existe una demanda potencial por parte de los consumidores» (apartado 49). Así pues, el concepto de producto nuevo exige que el solicitante de una licencia no pretenda «básicamente reproducir» los bienes y servicios que ya está ofreciendo el titular de los 
derechos. Este será uno de los aspectos sobre los que el TJCE tendrá que pronunciarse en el asunto Microsoft, puesto que mediante recurso de 7 de junio de 2004 esta empresa ha anunciado su intención de recurrir la Decisión de la Comisión analizada (DO C 179, 10 de julio de 2004). De hecho, la existencia de productos similares, si bien con interfaces diferentes, fue uno de los motivos esgrimidos por Microsoft para defender la acomodación a Derecho de su conducta.

Por lo que a la exclusión de la competencia en un mercado derivado respecta, el TJCE, siguiendo las conclusiones del Abogado General Antonio Tizzano (conclusiones 56 a 59), estableció que es suficiente con que pueda hablarse de un mercado potencial. Esto sucede, por ejemplo, cuando los productos o servicios protegidos por el derecho de propiedad intelectual son indispensables para desarrollar una actividad determinada y existe una demanda efectiva de ellos por parte de las empresas que pretenden desempeñar la actividad para la que son imprescidibles. Y ello aunque el servicio no se hubiera prestado hasta entonces de manera separada. Esto es precisamente lo que se planteaba, por ejemplo, en Bronner contra Mediaprint (STJCE de 26 de noviembre de 1998, Bronner/Mediaprint, Asunto C-7/97, Rec.1998, pp. 7791 y ss.). En esta sentencia el TJCE entendió que constituía un abuso de posición dominante el hecho de que una empresa periodística con una importante cuota de mercado en el sector de la prensa diaria que explotaba el único sistema de reparto de periódicos a domicilio existente en un Estado miembro, negara el acceso a dicho sistema de reparto al editor de un diario competidor quien, debido a su escasa tirada, no podía crear y explotar su propio sistema de reparto.

Finalmente, en relación con el carácter injustificado de la negativa, el TJCE someramente se limita a afirmar que la negativa dada a la solicitud de licencia de utilización debe estar justificada «por consideraciones objetivas» (apartado 51).

80. En definitiva, a la hora de valorar las «circunstancias excepcionales» que puedan constituir comportamiento abusivo según el artículo 82 TCE, la jurisprudencia del TJCE deja abierta la cuestión de cómo incorporar de modo coherente el equilibrio entre el esfuerzo creativo del titular de los derechos, por un lado, y las ventajas económicas que procure el correspondiente derecho de propiedad intelectual, por otro.

Posiblemente, la sentencia en la que se resuelva la demanda interpuesta por Microsoft contra la Decisión de la Comisión aquí analizada contribuya a arrojar nuevas pautas que ayuden a resolver la tensión entre ambos intereses en juego. 
Caso N. ${ }^{\circ}$ 13. Abuso de posición dominante: Dec. Com. 20 octubre 2004, Deutsche Post AG y RFA, COMP/38.745: Abuso de posición dominante cometido por el operador postal histórico de Alemania, por el hecho de una disposición legislativa que deberá ser modificada

NotA

81. En la presente Decisión, la Comisión se pronuncia en contra de ciertas disposiciones de la normativa postal alemana que excluye a las empresas comerciales de preparación de correo de la obtención de descuentos por la entrega de cartas preparadas y clasificadas en los centros de clasificación de Deutsche Post AG (en lo sucesivo, «DPAG»).

82. Desarrollando brevemente los hechos que motivaron esta Decisión, resulta que de conformidad con la legislación postal alemana aplicable, DPAG aplica descuentos a los grandes clientes que realizan envíos ya preparados a los centros de clasificación para su posterior distribución. El fundamento de los descuentos ofrecidos es el ahorro de costes que experimenta el operador postal público por el hecho de que los grandes clientes lleven el correo preparado. Por ello, los descuentos varían en función del número de objetos y su categoría, así como en función de la cercanía entre el centro clasificador y el destinatario. No obstante, y a pesar de que se produce una reducción de costes similar, DPAG no aplica los mismos descuentos a las empresas preparadoras que preparan y clasifican el correo de aquellas empresas que externalizan este servicio. En definitiva, el operador público aplica la tabla de descuentos de forma discriminatoria según se trate de empresas operadoras del servicio postal o, por el contrario, de particulares grandes empresas. Viola, así, el artículo 12 de la Directiva postal que establece la aplicación transparente y no discriminatoria de las condiciones de tarificación [Directiva 97/67/CE, de 15 de noviembre de 1997, relativa a las normas comunes para el desarrollo del mercado interior de los servicios postales de la Comunidad y la mejora de la calidad del servicio (DO L 15, 21 enero 1998)].

83. Antes de entrar en el análisis de la Decisión se impone una breve referencia al proceso de liberalización del servicio postal que facilite la mejor comprensión del asunto. Como es sabido, históricamente la mayor parte de los Estados miembros han prestado este tipo de servicios a través de un operador público de carácter monopolista. Y ello por entender que ésta era la forma de proteger y garantizar el secreto de las comunicaciones (E. Malaret i García: «Servicios públicos, funciones públicas, garantías de los derechos de los ciudadanos: Perennidad de las necesidades, transformación del contexto», Revista de Administración Pública, n. ${ }^{\circ}$ 145, eneroabril, 1998, pp. 49-87). 
Sin embargo, y puesto que la protección del interés público en juego puede igualmente garantizarse a través de obligaciones de carácter administrativo, a partir de 1992 con la publicación de Libro Verde sobre el desarrollo del mercado único de los Servicios Postales [COM (1991) 476 final] se inicia un proceso de apertura y liberalización del mercado postal que desembocará en la Directiva 97/67/CE supra mencionada.

Esta norma establece un programa de liberalización gradual que gira en torno al concepto de «servicio postal universal» (V. KRONENBERGERGER: «Service universal postal, contournement des monopoles postaux et droit communautaire de la concurrence. Quelques réflexions à la suite de l'arrêt de la CJCE du 10 fevrier 2000», Revue de droit des affaires internationales, n. ${ }^{\circ}$ 7, 2000, pp. 893-913). El principal propósito de éste es la creación y el mantenimiento de un servicio postal público que garantice, a tarifas accesibles, rentables y transparentes, el acceso a la red postal pública en todo el territorio nacional y se prestará por uno o varios proveedores que deberán ser notificados a la Comisión (en España la Disposición adicional primera de la Ley 14/2000, de 29 de diciembre, de Medidas Fiscales, Administrativas y del Orden Social atribuyó la obligación de prestar el servicio postal universal a la «Sociedad Estatal Correos y Telégrafos»). A su vez, dentro del servicio postal universal se distingue entre servicios reservados y no reservados de forma que, siempre que sea necesario para el mantenimiento del servicio, el proveedor universal podrá prestar los servicios reservados, entendiendo por tales los establecidos en el artículo 7 de la Directiva. A saber: «la recogida, la clasificación, el transporte y la distribución de los envíos de correspondencia interna, tanto si se trata de distribución urgente como si no, cuyo precio sea inferior a cinco veces la tarifa pública de un envío de correspondencia de la primera escala de pesos de la categoría normalizada más rápida, cuando ésta exista, siempre que su peso sea inferior a $350 \mathrm{~g}$ » [el ámbito de reserva máximo del servicio postal universal ha sido modificado por la Directiva 2002/39/CE del Parlamento Europeo y del Consejo, de 10 de junio de 2002, por la que se modifica la Directiva 97/67/CE con el fin de proseguir la apertura a la competencia de los servicios postales de la Comunidad (DO L 176, 5 julio 2002)].

Junto al concepto de «servicio postal universal», se encuentra el de «servicio liberalizado» al que podrá acceder cualquier proveedor que obtenga la preceptiva autorización o licencia.

En cualquier caso, tal y como la propia Comisión reconoce en la Comunicación de 30 de mayo de 2000 [COM (2000) 319 final, relativa a la propuesta para la modificación de la Directiva postal con el fin de proseguir la apertura de la competencia de los servicios postales], la Directiva ha supuesto una apertura muy limitada del mercado, si bien se trata del primer estadio dentro de un proceso de liberalización de carácter gradual. 
84. Expuesto lo anterior, el artículo 51 de la Ley postal alemana induce a DPAG (proveedor del servicio postal universal alemán) a extender su posición en el mercado reservado a los servicios de preparación de envíos de correo. Por ello, para justificar los descuentos discriminatoriamente aplicados, el operador público alega en su defensa que los servicios que presta son servicios reservados.

Pues bien, la Decisión de la Comisión analizada niega tal condición puesto que el artículo 7 de la Directiva 97/67/CE únicamente reserva los servicios postales a partir del momento de la recogida o entrada de los envíos en los centros pertenecientes a la red pública. Se trata de una precisión que ya realizó en el asunto SNELDP (Dec.Com. 23 octubre 2001, COMP/37.133), en el que adoptó una Decisión similar con arreglo al artículo 86 TCE, si bien en este caso la destinataria era Francia. Concretamente, afirmó que «el monopolio no se extiende a la preparación de correo previa al transporte ni a la distribución propiamente dichas, es decir, el acondicionamiento, la recogida y la clasificación del correo entregado a La Poste. Por consiguiente, los servicios de preparación de correo pueden ser prestados por empresas distintas de La Poste» (apartado 58). Es decir, de las afirmaciones de la Comisión se deduce que el legislador alemán interpreta incorrectamente el ámbito de los servicios reservados en perjuicio de los competidores de DPAG.

85. La Decisión de la Comisión de considerar contrarias al Derecho de la competencia determinadas disposiciones de la ley postal alemana se fundamenta sobre el artículo 86.1 TCE, que prohíbe a los Estados miembros adoptar o mantener en vigor cualquier medida contraria a las normas del Tratado, especialmente a las relativas al Derecho de la competencia.

Son varias las precisiones que se imponen a este respecto. Por una parte, en relación con la situación de posición dominante, es jurisprudencia reiterada el que una empresa que disfruta de un régimen de monopolio legal en una parte sustancial del mercado común ocupa una posición de dominio en el sentido del artículo del artículo 86 TCE (en este sentido, entre otras, STJCE de 23 de abril de 1992, Höfner/Macroton, asunto C-41/90, Rec. 1991, pp. 1979 y ss., apartado 28; STJCE de 18 de julio de 1991, ERT, asunto C-260/89, Rec.1991, pp. 2925 y ss., apartado 31; STJCE de 19 de mayo de 1993, Corbeau, asunto C-320/91, Rec. 1993, pp. 2538 y ss., apartado 9). Por otra parte, el hecho de que el monopolio se ejerza en el territorio de un único Estado miembro no le niega el interés comunitario al mismo. De hecho, el TJCE ha afirmado en reiteradas ocasiones que el territorio de un Estado miembro puede constituir una parte sustancial del mercado común (STJCE de 9 de noviembre de 1983, 
NV Nederlandsche Banden-Industrie-Michelin/Comisión, Asunto 322/81, Rec. 1983, pp. 3461 y ss., apartado 28; STJCE de 5 de octubre de 1994, Societé civile agricole du centre d'insemination de la Crespelle/Cooperative d'élevage et d'insemination artificielle du département de la Mayenne, asunto C-323/93, Rec.1994, pp. 5077 y ss., apartado 17; STJCE de 26 de noviembre de 1998, Oscar Brönner GMBH \& Co./Mediaprint, asunto C-7/97, Rec.1998, p. 7791, apartado 36).

Mayores complejidades pudiera plantear el tema del abuso de la posición de dominio. En este ámbito, y a raíz de la jurisprudencia en el asunto ERT anteriormente citada, se empezó a hablar de la Teoría del Abuso Automático. Esta teoría llevaba a entender que cualquier norma estatal que incitara o permitiera a las empresas públicas violar las normas de la U.E., incluidas las que prohíben los acuerdos restrictivos del comercio y el abuso de posición dominante, era contraria al artículo 82 y, por lo tanto, constituía un abuso de la posición de dominio. Y ello con independencia de que el abuso llegara o no a consolidarse (al respecto, Chr. Gavalda/G. Parleani: Droit des affaires de l'Union europeéne, 2. ${ }^{a}$ ed., París, 1998, pp. 383-391). Traducida al asunto que nos ocupa, la Teoría del Abuso Automático implicaría que la legislación que extiende la posición de dominio del operador público a los servicios de preparación de los envíos de correo, donde también es un operador destacado, constituiría automáticamente una infracción de las prohibiciones contenidas en los artículo 82 y 86 TCE. Las alegaciones de $D P A G$ se dirigen principalmente a negar la correlación automática entre la ostentación de una posición monopolística y el abuso de la misma, basándose en que la Teoría del Abuso Automático ha sido superada por la propia práctica del TJCE (STJCE de 5 de octubre de 1994, Societé civile agricole du centre d'insemination de la Crespelle/Cooperative d'élevage et d'insemination artificielle du département de la Mayenne, asunto C-323/93, Rec.1994, pp. 5077 y ss., apartado 18). No obstante, pese a la argumentación del operador público alemán, no puede entenderse que la Decisión actualice nuevamente la Teoría del Abuso Automático. De hecho, no se limita a decir que el artículo 51 de la ley postal alemana permita o incite a las empresas públicas a violar las normas de la competencia de la Unión Europea: la Comisión constata la producción del abuso en la medida en que DPAG cobra la tarifa entera a los grandes envíos postales preparados y entregados por empresas especializadas cuando, si estos mismos envíos fueran realizados por el remitente mismo, tendrían derecho a la aplicación del descuento. Con ello, el operador público se beneficia de un ahorro de costes sin ningún tipo de compensación a las empresas competidoras. Como consecuencia de ello, éstas no pueden ofrecer ningún descuento a sus clientes y pierden así su atractivo comercial. 
86. Esta es la segunda Decisión en que la Comisión tiene que pronunciarse en el ámbito de los servicios de preparación de correos. No obstante, son múltiples los pronunciamientos sobre asuntos similares o análogos. Piénsese que el origen de los principales problemas de la liberalización de los mercados radica en que en numerosas ocasiones la misma sólo puede conseguirse a través del acceso de los nuevos proveedores a una infraestructura de red ya existente, generando tensiones entre el proveedor que anteriormente ostentaba una situación de monopolio y los recientes operadores. Así pues, a la vista de los diversos pronunciamientos dictados en la materia puede concluirse que la evolución del proceso liberalizador depende del sentido y alcance que se dé al concepto «servicio universal».

\section{Marta Casado Abarquero}

Caso N. ${ }^{\circ}$ 14. Abuso de posición dominante: STPI 26 enero 2005, Piau/ Féderation Internationale de Football Association (FIFA), T-193/02, Rec., p. I-1113: Posición dominante colectiva

\section{NotA}

87. En el presente asunto, el TPI rechaza el recurso interpuesto contra la Decisión de la Comisión en la que desestima la denuncia interpuesta por el Sr. Piau contra el Reglamento de la Féderation International de Football Association (en lo sucesivo, «FIFA») de 10 de diciembre de 2000 sobre los agentes de jugadores.

88. Antes de entrar en el análisis de la sentencia conviene hacer una breve introducción de los antecedentes fácticos de la Decisión recurrida. Los hechos que dan lugar a esta resolución se remontan a 1994, año en el que para poner fin a determinadas prácticas perjudiciales para los jugadores y los clubes, la FIFA adoptó un Reglamento sobre los agentes de jugadores. El texto fue denunciado ante la Comisión por considerar que las restricciones impuestas al acceso a la profesión eran incompatibles con los artículo 81 y 82 TCE y con los artículos 49 y siguientes del Tratado. Concretamente, se denunciaba la ausencia de medios de impugnación o recurso frente a las decisiones y sanciones previstas, que las modalidades de examen establecidas eran opacas, y la exigencia de aval, excesiva.

Tras estas denuncias la Comisión realizó una investigación pormenorizada de las normas establecidas por la FIFA relativas a los agentes de jugadores de fútbol. Esta investigación desembocó en el envío a la FIFA, el 19 de octubre de 1999, de un pliego de cargos en el que el Ejecutivo comunitario consideraba que las normas de la Federación constituían acuerdos que limitaban la competencia al impedir o limitar el acceso a la profesión 
de personas que tenían las competencias profesionales necesarias. En particular, cuestionaba que las disposiciones relativas al carácter obligatorio de la licencia, a la negativa de su concesión a personas jurídicas, a la prohibición de que clubes y jugadores recurriesen a agentes no licenciados, a la exigencia de un aval bancario y a las sanciones fueran compatibles con el artículo 81 TCE.

A raíz de este procedimiento, la FIFA decidió revisar las normas en cuestión y el 10 de diciembre de 2000 adoptó un nuevo Reglamento que entró en vigor el 1 de marzo de 2001 que fue modificado, en último lugar, el 3 de abril de 2002. Según el nuevo Reglamento el acceso a la profesión estaba basado ahora en criterios objetivos y transparentes y la exigencia de aval o fianza era sustituida por la suscripción de una póliza de responsabilidad civil en el ejercicio de la profesión.

En vista de las mejoras introducidas y de las supresiones efectuadas en el nuevo Reglamento, la Comisión decidió archivar el asunto. Aún así, el Sr. Piau mantuvo la denuncia alegando que las infracciones del artículo 81 persistían. Mediante Decisión de 15 de abril de 2002, la Comisión desestimó esta denuncia por entender que las disposiciones restrictivas más importantes habían sido derogadas, que las restricciones subsistentes podían acogerse a una exención con arreglo al artículo 81.3 TCE y que el artículo 82, relativo al abuso de posición dominante, no era aplicable al caso examinado.

89. A continuación se procederá a analizar la solución dada por el Tribunal de Primera Instancia a cada una de las cuestiones que en este asunto se planteaban, esto es, la procedencia de la exención prevista en el artículo 81.3 TCE, y la existencia de una posición dominante colectiva. Por lo que al primer punto respecta, El Tribunal de Justicia de la UE dio el visto bueno al Reglamento de la FIFA sobre agentes de jugadores de fútbol, al considerar que no atentaba contra el Derecho comunitario. Así, entendió que el sistema de licencias imponía restricciones más cualitativas que cuantitativas a la profesión de agente, tratando de proteger a los jugadores y a los clubes. En este sentido, tomó particularmente en consideración los riesgos en que incurren los jugadores, cuyas carreras profesionales son cortas, en caso de transferencias mal negociadas por parte de sus agentes. Por todo ello concluye que el Reglamento puede acogerse al sistema de exenciones previsto en el artículo 81.3 TCE puesto que queda demostrado que las barreras de acceso a esta actividad económica no imponen restricciones que no sean indispensables y, como contrapartida, contribuye a fomentar el progreso económico y reserva a los usuarios una participación equitativa en el beneficio resultante.

90. En relación con la existencia de una posición dominante colectiva, el artículo 82 TCE prohíbe «la explotación abusiva, por parte de una o más empresas, de una posición dominante en el mercado común o en 
parte sustancial de éste». Es precisamente la expresión «más empresas» la que permite que una posición de dominio pueda ser ocupada por dos o más agentes económicos, jurídicamente independientes entre sí (V. KORAH: «Gencor v. Comisión: Collective Dominance», European Competition Law Review, 20, 1999, p. 339). En cualquier caso, en la práctica el concepto de posición dominante colectiva (kollektive beherrschende Stellung) se ha mostrado como una noción ambigua e imprecisa. En definitiva, no se trata de un concepto jurídico sobre el que la doctrina sea pacífica por lo que su exacto significado y alcance debe ser analizado a través de las prácticas de la Comisión, del TPI y del TJCE (G. NIELS: «Collective dominance: more than just oligopolistic interdependence», European Competition Law Review, 22, 2001, pp. 168-172).

Pues bien, en el ámbito de aplicación del Reglamento de concentraciones, la Sentencia Airtours (STPI de 6 de junio de 2002, Airtours/Comisión, T-342/1999, Rec. p. II-2895, apartado 62) viene a señalar que, para sostener que se va a crear una posición dominante colectiva, no es suficiente con que el número de empresas del sector se reduzca: es necesario acreditar que este reducido número de empresas va a desarrollar comportamientos paralelos, lo cual exigirá demostrar que todas ellas conocen el comportamiento de las demás de tal forma que les estimule a adoptar una misma línea de actuación y les disuada de no romper ese comportamiento paralelo. Igualmente, es preciso probar que el resto de competidores (reales o potenciales), clientes y consumidores no van a oponerse a esa forma de actuación. En definitiva, la existencia de una posición dominante colectiva exige que se cumplan cumulativamente tres requisitos: en primer lugar, que todas las empresas miembros del oligopolio dominante pueden conocer el comportamiento de los demás miembros para comprobar si están adoptando o no la misma línea de acción; en segundo término, que exista un incentivo a no apartarse de la línea de conducta; y, finalmente, que la reacción previsible de los competidores, clientes y consumidores no cuestione los resultados esperados de la línea de acción común.

91. Por lo que a la primera condición respecta, la naturaleza jurídica de la FIFA impone unas breves consideraciones. Es cierto que la Federación, como tal, no es un agente económico. Sin embargo, la FIFA tiene como miembros a asociaciones nacionales que agrupan a clubes para los que la práctica del fútbol constituye una actividad económica strictu sensu. Por consiguiente, estos clubes son empresas en el sentido del artículo 81 TCE y, del mismo modo, las asociaciones nacionales que los agrupan son asociaciones de empresas en el mismo sentido de esta disposición. Esta conclusión es plenamente compatible con la acepción amplia dada al concepto de empresa, comprensivo no sólo de las estructuras económicas tradicio- 
nalmente conocidas como tales, sino también de instituciones de interés público, asociaciones benéficas o deportivas, comunidades religiosas, sindicatos profesionales, agrupaciones de interés económico, sociedades de hecho... (en este sentido, resistente al paso del tiempo, J.I. FOnT GALÁN: La Libre Competencia en la Comunidad Europea, Publicaciones del Real Colegio de España, Bolonia, 1986, p. 64).

92. El Reglamento de la FIFA sobre los agentes de los jugadores incide directamente en la apreciación de la concurrencia del segundo de los requisitos. Efectivamente, el Reglamento vincula de forma duradera y permanente a las asociaciones nacionales miembros de la FIFA y los clubes que están integrados en ella. Son normas que han aceptado y que no pueden contrariar bajo pena de sanción. Concurren así los presupuestos típicos necesarios para entender que existen «incentivos a no apartarse de la línea de conducta»: la existencia de un acuerdo y la imposición de represalias en aquellos casos en que uno de los operadores se aparte de la línea común de comportamiento. No es preciso, por lo tanto, recurrir a la doctrina flexibilizadora del TJCE que entiende que la existencia de vínculos o factores económicos de correlación entre las empresas afectadas no necesariamente exige la existencia de un acuerdo o de otro tipo de relaciones jurídicas (en este sentido, STJCE de 16 de marzo de 2000, Compagnie maritime belge de transports SA y otros /Comisión, asuntos acumulados C-395/96 P y C-396/96 P, Rec. p. I-1365, apartado 45).

93. Finalmente, por lo que a que la incapacidad de los competidores y consumidores para modificar los resultados esperados de la línea de acción común respecta, es preciso señalar, como bien apunta el TPI, que en el presente caso el mercado afectado por la normativa controvertida es un mercado de prestación de servicios en el que los compradores son los jugadores y los clubes, y los vendedores son los agentes. Por ello, el Sr. Piau sostiene que la FIFA actúa en régimen de monopolio, puesto que representa los intereses de todos los compradores y, en su situación de «comprador único», impone sus condiciones a los oferentes. El hecho de que estos últimos no puedan contrariar las normas del Reglamento de la FIFA puesto que la contravención de las mismas conlleva la imposición de sanciones que pueden llegar, incluso, a su expulsión del mercado, inhibe todo poder de reacción y obliga a concluir que los clubes ostentan una posición dominante colectiva.

94. Por ello, el Tribunal considera un error manifiesto la afirmación de la Comisión en el sentido de negar que la FIFA ostente una posición dominante en el mercado de los servicios de los agentes de los jugadores. No obstante, pese a ello, no varía la conclusión última a la que llega la 
Comisión puesto que considera que el Reglamento de la FIFA no impone restricciones cuantitativas al acceso a la actividad de agente de jugadores que sean perjudiciales para la competencia, sino restricciones de carácter cualitativo que pueden estar justificadas.

Sin embargo, quizá por no afectar al resultado final del fallo, el Tribunal comete, en nuestra opinión, una imprecisión al justificar la ausencia de abuso de posición dominante en el hecho de que el Reglamento pueda acogerse a la exención prevista en el artículo 81.3 TCE (apartado 117). Pues bien, esta afirmación desconoce los pronunciamientos que existen tanto de la Comisión como del Tribunal de Primera Instancia y del TJCE que niegan que la existencia de una exención se oponga a la aplicación del artícuo 82. Así por ejemplo, en el asunto Tetra Pak (STPI de 10 de julio de 1990, Tetra Pak Rausing/Comisión, T-51/89, Rec.1990, pp. 301 y ss.) el Tribunal rechazó el argumento del demandante de que el artículo 82 TCE no era aplicable a los acuerdos exentos por el artículo 81.3 TCE porque ambas normas obedecían a unos mismos fines. Y lo rechazó contestando que las exenciones del artículo 81.3 sólo se refieren a las ententes, y que el abuso, por su propia naturaleza, excluye toda posibilidad de exención (en el mismo sentido, STPI de 8 de octubre de 1996, Asuntos acumulados T-24/93, T-25/93, T-26/93 y T-28/93, $C M B, C M B T$ y Dafra-Lines/Comisión, Rec.1996, p.1201, apartado 152; STJCE de 11 de abril de 1989, Ahmed Saeed Flugreisen, asunto 66/86, Rec.1989, p. 803, apartado 32).

En definitiva, una imprecisión justificada, quizá, por la ausencia de trascendencia para el fallo final de una sentencia en la que, nuevamente, se pone de relieve que la ostentación de una posición de dominio, ya sea individual o colectiva, no necesariamente implica un abuso de la misma.

Marta Casado Abarquero

Caso N. ${ }^{\circ}$ 15. Abuso de posición dominante: Dec.Com. 22 junio 2005, Coca-Cola, COMP/A.39.116/B2, DO L 253 de 29 septiembre 2005: Decisión compromiso (Coca-Cola se compromete a no abusar de su posición dominante y se libra de toda sanción)

\section{NotA}

95. En el presente comentario se analiza una de las primeras «decisiones de compromiso» adoptada tras la entrada en vigor del Reglamento 1/2003 del Consejo, de 16 de diciembre de 2002, relativo a la aplicación de las normas sobre competencia previstas en los artículo 81 y 82 del Tratado ( $D O \mathrm{~L} \mathrm{1,} \mathrm{de}$ 4 de enero de 2003). En la Decisión estudiada, la Comisión, tras analizar los compromisos asumidos por las denunciadas y las observaciones presentadas 
por terceros, estima que aquéllos son suficientes para resolver los problemas de competencia que se planteaban en el mercado afectado y les dota de carácter obligatorio hasta el 31 de diciembre de 2003.

96. Adentrándonos en los hechos que motivan la Decisión, éstos se remontan a 1996, 1999 y 2001, años en que la Comisión recibió una serie de denuncias de abuso de posición dominante por parte de The Coca-Cola Company (en lo sucesivo, «TCCC») y de sus tres embotelladores principales, Bottling Holdings Sarl, Coca-Cola Erfrischugsgetränke AG y CocaCola Hellenic Bottling Company SA. Como consecuencia de estas denuncias, la Comisión llevó a cabo un conjunto de inspecciones con arreglo al entonces vigente Reglamento (CEE) n. ${ }^{\circ} 17$.

No obstante, el 29 de septiembre de 2004 la Comisión Europea incoó el procedimiento con vistas a adoptar una decisión con arreglo al artículo 9 del Reglamento 1/2003, en vigor a partir del 1 de mayo de 2004. De conformidad con este precepto, la Comisión en su análisis preliminar detectó una serie de problemas de competencia en relación con determinadas prácticas comerciales de TCCC y sus embotelladoras. Concretamente, la Comisión comprobó que éstas, ostentando conjuntamente en algunos de los mercados nacionales una posición de dominio en el suministro de bebidas gaseosas sin alcohol, llevaban a cabo una serie de prácticas de dudosa compatibilidad con los artículos 81 y 82 TCE. Las prácticas que más inquietaban al Ejecutivo comunitario consistían, por un lado, en cláusulas de exclusividad en el mercado minorista (supermercados y otros comercios al por menor) por las que los supermercados se obligaban a reservar una amplia zona de sus expositores de bebidas gaseosas sin alcohol a productos con marca $T C C$; por otro, los descuentos condicionados a que el cliente alcanzara trimestralmente umbrales de compra especificados individualmente en el canal horeca (venta en establecimientos de consumo); finalmente, las empresas también imponían ciertos requisitos de exclusividad en la instalación de refrigeradores, surtidores o máquinas expendedoras. El análisis concluía que estas prácticas obstaculizaban el acceso de los competidores a los puntos de venta, resultando perjudicado en última instancia el consumidor. En respuesta a este análisis preliminar, el 19 de octubre de 2004 las partes presentaron una serie de compromisos a la Comisión. De conformidad con el artículo 27.4 del Reglamento 1/2003, el 26 de noviembre de 2004 se publicó en el Diario Oficial una comunicación en la que se resumía el asunto y los compromisos asumidos por las partes, invitándose a los interesados a formular observaciones en el plazo de un mes a partir de la fecha de la publicación ( $D O$ C 289, de 26 noviembre 2004). Tras recibir las observaciones, el 25 de febrero de 2005 las partes presentaron 
una propuesta modificada de compromiso en los que, resumidamente, se comprometían a:

a) No imponer cláusulas de exclusividad, de forma que los clientes de Coca-Cola tuvieran libertad en todo momento para comprar y vender bebidas gaseosas sin alcohol de cualquier proveedor.

b) No ofrecer descuentos por objetivos y volumen. Con ello CocaCola no recompensaría a sus clientes por el mero hecho de que mantuvieran o aumentaran el volumen de productos Coca-Cola adquiridos.

c) No utilizar las marcas más reconocidas de Coca-Cola para vender productos que gozaran de menos popularidad en el mercado.

d) Permitir un $20 \%$ de espacio libre para otras marcas de bebidas en los refrigeradores gratuitos que proporcionara Coca-Cola siempre que en el establecimiento no hubiera ningún otro aparato de refrigeración.

Como consecuencia de estos acuerdos, se llegó a la conclusión de que no había motivos para más actuaciones. Por ello, mediante la Decisión de 22 de junio aquí analizada la Comisión dota de carácter vinculante a los compromisos asumidos por TCCC y sus embotelladoras hasta el 31 diciembre de 2010.

97. La fecha en la que fueron realizadas las denuncias por prácticas anticompetitivas, así como el hecho de que una de las empresas denunciadas estaba constituida en Atlanta (Estados Unidos) obligan a hacer una serie de precisiones en torno al ámbito de aplicación del Reglamento 1/2003. En este sentido, conviene adelantar que concurren los presupuestos de aplicación material, personal, temporal y espacial que determinan la aplicación del mismo al asunto objeto de análisis.

Por lo que al presupuesto de aplicación material y personal respecta, ninguna duda ofrece la propia redacción del artículo 1 del Reglamento puesto que, de un lado, resulta de aplicación a los acuerdos entre empresas, decisiones de asociaciones de empresas y las prácticas concertadas que puedan afectar al comercio entre los Estados miembros y que tengan por objeto restringir o falsear el juego de la competencia dentro del mercado común (artículo 1.a) del Reglamento en relación con el artículo 81 TCE); y de otro, extiende su alcance a las explotaciones abusivas, por parte de una o más empresas, de una posición dominante en el mercado común o en una parte sustancial del mismo (artículo 1.c) del Reglamento, en relación con el artículo 82 TCE).

Mayores complejidades plantea el presupuesto de aplicación temporal. En este sentido, el artículo 45 del Reglamento 1/2003 establece que su entrada en vigor se producirá el 1 de mayo de 2004. Esto no obstante, el 
artículo 34.2 establece que los actos de procedimiento realizados al amparo del Reglamento n. ${ }^{\circ} 17$, predecesor de aquél, conservarán sus efectos de cara a la aplicación del Reglamento 1/2003. Así pues, pese a que las denuncias fueron cursadas en años previos al ejercicio 2004, las actos de investigación llevados a cabo por la Comisión mantienen su vigencia a efectos del nuevo procedimiento incoado por ésta el 29 de septiembre de 2004.

Para concluir, el presupuesto de aplicación territorial debe ser objeto de una valoración especial desde el momento en que una de las empresas no tiene su domicilio social en territorio comunitario. Así, pese a que las empresas embotelladoras están domiciliadas en Luxemburgo, Alemania y Grecia respectivamente, $T C C C$ es una sociedad estadounidense con domicilio social en Atlanta. Pues bien, como norma general se puede afirmar que las normas comunitarias son aplicables a las conductas que falsean la competencia en el interior del Mercado Común, lo que implica que las reglas europeas en materia de competencia determinan, también, el régimen de responsabilidad de empresas con sede fuera del mercado comunitario siempre que su conducta haya impedido, restringido o falseado el juego de la competencia dentro del Mercado Común. Se trata de la denominada Doctrina del Efecto tantas veces impugnada por las empresas situadas fuera del territorio comunitario pero que ha sido perfilada por la Comisión y por el TJCE desde fechas verdaderamente recientes (STJCE 25 noviembre 1971, Béguelin Import/G.L. ImportExport, 22/71, Rec. 1971, p. 949; STJCE 14 de julio 1972, Imperial Chemical Industries Ltd./Comisión, 48/69, Rec.1972, p. 619; STJCE 21 febrero 1973, Europemballage Corporation et Continental Can Company/Comisión, 6/72, Rec.1973, p. 215). No obstante, el verdadero punto de inflexión en la consolidación de esta Doctrina lo constituyó la decisión dada por la Comisión y por el TJCE en el asunto denominado pasta de madera, asunto en el que por primera vez la Comisión condena una entente en la que todas las empresas destinatarias de la Decisión operaban con regularidad en el mercado comunitario pero tenían su sede fuera de la Comunidad (Dec.Com. 19 diciembre 1984, Pâte de bois, DOCE L 85, de 26 marzo 1985, y STJCE 27 septiembre 1988, Ahlström Osakeyhtiö y otros/Comisión, 89, 104, 114, 116, 117 y 125 a 129/85, Rec., p. 5193). En realidad, el ámbito de aplicación territorial del Derecho Comunitario en esta materia no puede sino tener únicamente en consideración el lugar en el que los comportamientos de las empresas surten efectos puesto que, si la aplicabilidad del mismo dependiera del lugar en el que se adopta el acuerdo o del país en el que las empresas están domiciliadas, se estaría introduciendo una vía de escape para eludir la imperatividad del Derecho de la competencia.

98. Respecto al procedimiento elegido, esta es la segunda ocasión en que la Comisión utiliza el sistema de «Decisión Compromiso» establecido 
en el artículo 9 del Reglamento 1/2003, en virtud del cual se pone fin a los procedimientos por conductas anticompetitivas, declarando obligatorios los compromisos asumidos por las empresas. Esta es una de las novedades introducidas por el Reglamento 1/2003 puesto que, a diferencia de su antecesor, confiere a la Comisión, en concordancia con lo establecido en el Reglamento (CE) 139/2004 sobre el control de las concentraciones entre empresas ( $D O$ L 124 de 29 enero 2004), la posibilidad de aceptar los compromisos que ofrezcan las partes dirigidos a poner fin a la infracción cometida, convirtiéndolos en obligatorios para las empresas afectadas.

El carácter vinculante de estos compromisos supone que los mismos podrán ser invocados por los particulares ante los tribunales nacionales así como que la Comisión pueda, en cualquier momento, volver a incoar el procedimiento si se ha producido un cambio considerable en los hechos, si se facilitó información incorrecta o desvirtuada o si la empresa viola los compromisos asumidos.

Pues bien, este procedimiento fue utilizado por la Comisión por primera vez en la Decisión de 19 de enero de 2005 (Dec.Com. 19 enero 2005, Ligaverband, COMP/C-2/37.214, DO L 134 de 27 mayo 2005). En esta Decisión se asumían los compromisos contraídos por la Federación de la Liga de Fútbol Alemana (Ligaverband) para la comercialización de los derechos televisivos del campeonato alemán de fútbol (Bundesliga), dando un nuevo impulso a la liberalización de los derechos de retransmisión, sobre todo en el ámbito de los nuevos medios de comunicación tales como Internet de banda ancha.

99. La Decisión analizada constituye, en definitiva, una de las primeras aplicaciones de la Decisión Compromiso, instrumento jurídico que sin duda, desde el momento en que los compromisos son publicados en el Diario Oficial y en Internet y se da traslado a los terceros interesados para que formulen observaciones, aportará una mayor transparencia al conjunto del mercado.

Marta Casado Abarquero

\section{Concentraciones}

Caso N. ${ }^{o}$ 16. Concentraciones: Decisión de la Comisión 19 julio 2004, SONY/BMG, M. 3333

NotA

100. La Comisión autorizó el 19 de julio de 2004 la creación de una filial común entre Bertelsmann AG y Sony Corporation of America a pesar de que la operación reduce de cinco a cuatro el número de los principales operadores de grabaciones musicales. La operación se autorizó en virtud del 
artículo 8, apartado 2 del Reglamento (CEE) n. ${ }^{\circ}$ 4064/89 del Consejo, de 21 diciembre 1989, hoy día derogado por el Reglamento (CE) 139/2004 del Consejo, de 20 enero 2004.

Bertelsmann es una empresa de medios de comunicación que actúa a nivel internacional en televisión, radio, edición de libros y revistas y clubes de libros y música. Además realiza, a través de su empresa subsidiaria Bertelsmann Music Group (BMG), actividades de grabación y edición musical. Sony, por su parte, realiza actividades a nivel internacional de grabación y edición musical, aparatos electrónicos industriales y de consumo y ocio, actuando en el merado de las grabaciones musicales a través de su filial Sony Music Entertainment.

La nueva empresa en participación Sony BMG se dedicará a las actividades de A\&R (artistas y repertorio) que consiste en el descubrimiento y desarrollo de artistas. También se ocupará de la comercialización y venta de grabaciones musicales. Para ello, las matrices aportan su actividad global de grabaciones musicales exceptuando las actividades de Sony en Japón. La nueva entidad, sin embargo, no se dedicará a otras actividades relacionadas como son la edición, la producción o la distribución de música.

La Comisión diferencia varios mercados de referencia: las grabaciones musicales, la música en línea y la edición musical. Si bien en cada uno de los anteriores la Comisión pudo identificar mercados de productos diferentes no fue necesaria la segregación, ya que la evaluación de la operación no hubiera sido diferente. Los tres mercados de referencia son mercados de ámbito nacional.

101. En la evaluación de la operación, la Comisión diferencia seis posibles efectos perniciosos sobre la competencia: el posible refuerzo de la posición de dominio colectivo en los mercados de grabaciones musicales, la posible creación de un dominio colectivo en los mercados de grabaciones musicales, la posible creación de una posición dominante única en los mercados de grabaciones musicales, el posible dominio colectivo en el mercado al por mayor de licencias para música en línea, la posible posición de dominio única en los mercados de distribución de música en línea y los posibles efectos colaterales en la edición musical. Y realiza un profundo análisis diferenciado de cada uno de ellos.

En el análisis del posible refuerzo de la posición de dominio colectiva en los mercados de grabaciones musicales, la Comisión aplica la jurisprudencia del TJCE creada en el caso Airtours. Conforme a esta jurisprudencia para la acreditación de la existencia de una posición de dominio colectiva entre las distintas empresas del mercado, y, por tanto, para su posible refuerzo mediante la operación, la Comisión debe demostrar que existe antes de ejecutarse la operación: 1) un entendimiento común de las condiciones 
de coordinación, 2) la capacidad para controlar si se cumplen dichas condiciones, 3) la existencia de un mecanismo de disuasión en caso de incumplimiento y 4) la imposibilidad de que competidores y clientes puedan poner en peligro los beneficios que se esperan de la coordinación.

Para saber si las empresas del sector mantuvieron una política de precios coordinada en los Estados miembros durante los tres años previos a la notificación, la Comisión comparó en cada uno de los Estados: la evolución de los precios netos medios al por mayor, los precios publicados para distribuidores, los coeficientes de precios brutos y netos y los descuentos en facturas aplicados por las cinco principales empresas tanto a mayoristas como a minoristas en cada Estado miembro.

Por lo que respecta a la posible coordinación de los precios al por mayor de las cinco empresas principales, la Comisión estudió, en primer lugar, el paralelismo de la evolución de los precios de los 100 álbumes más importantes de cada una de ellas en los Estados miembros más grandes, esto es, Alemania, España, Francia, Italia y Reino Unido. Las ventas de estos álbumes representa entre el $70 \%$ y el $80 \%$ de las ventas totales respectivas de música de las cinco empresas estudiadas por lo que la muestra es suficientemente representativa. A pesar de que la Comisión encontró cierto paralelismo y una evolución similar de los precios en esos cinco países no consideró suficientemente demostrada la existencia de una política de precios coordinada.

En segundo lugar, y para complementar la investigación anterior, la Comisión comprobó la existencia de listas de precios publicadas para distribuidores como medio de coordinación de precios y examinó la transparencia y la alineación de los descuentos para comprobar la posibilidad del control efectivo del comportamiento competitivo. Aunque la Comisión encontró indicios de que se podían haber utilizado la publicación de precios para los distribuidores como medio para coordinar los precios descubrió que los descuentos variaban entre las cinco empresas principales y que algunos descuentos no eran los suficientemente transparentes como para demostrar la existencia de colusión.

Finalmente, la Comisión examinó las condiciones del mercado para saber si existían condiciones que provocaran el dominio colectivo, condiciones analizadas también en el caso Airtours. Así, la Comisión observó, por un lado, la homogeneidad del producto en cuyo estudio hay que diferenciar varias cuestiones ya que, como advierten las partes en la notificación el lanzamiento de cada disco es único, sin embargo, como los consumidores adquieren en su mayoría discos de diferentes artistas y géneros de música el resultado es que se puede hablar de cierta sustituibilidad entre ellos. Además, a pesar de la gran heterogeneidad de contenidos, la forma de fijar los precios y la comercialización de la música está muy estandarizada teniendo en cuenta siempre el éxito del álbum. 
102. En cuanto al análisis de la transparencia del mercado la Comisión no encontró pruebas suficientes para concluir que ciertas dificultades existentes que la reducen, como el hecho de que el control de las campañas de descuentos requiera un control en el nivel de los álbumes, hayan sido superadas.

103. Finalmente, la Comisión explora con detenimiento las posibles represalias que pudieran adoptar las empresas contra las que se alejen del comportamiento anticompetitivo. Indicios sobre represalias en el pasado pueden identificar la existencia de una posición colectiva en el pasado. Por ello, la Comisión examina si se ha vuelto de forma temporal al comportamiento competitivo o si hay signos de exclusiones de empresas desleales de acuerdos y joint ventures para la realización de compilaciones. Del estudio realizado por la Comisión se desprende que la inclusión de artistas de diferentes compañías discográficas es un factor importante para el éxito del disco compilatorio. Estos discos suponen entre un $15 \%$ y un $20 \%$ del total del mercado de las grabaciones musicales. La Comisión verificó los acuerdos y creaciones de empresas en participación en los que participaron las empresas en cuestión y el resto de las cinco grandes operadoras del mercado. Estos acuerdos suelen tener una duración limitada a un año y, en caso de que una empresa se desviara de la política de coordinación, podría ser excluida de los mismos. Sin embargo, la Comisión, tras el estudio de los contratos firmados por las compañías en los dos años precedentes a la notificación, no ha encontrado pruebas suficientes de que tales mecanismos de represalias se hayan aplicado en el pasado.

La Comisión extendió su detallado estudio a cada uno de los Estados miembros más pequeños y a Noruega y, aunque existía un «considerable grado de paralelismo entre los precios publicados para los distribuidores de las cinco empresas principales que, en principio, podían utilizarse como base por estas cinco empresas principales para alinear los precios», también puso la profunda investigación de manifiesto que existían «algunas diferencias en el nivel de descuentos y déficits de transparencia en cuanto a determinados descuentos».

Todo ello lleva a la Comisión a concluir que no ha encontrado las suficientes pruebas, requeridas por el TJCE desde la jurisprudencia Airtours, de la existencia de una posición de dominio colectivo por parte de las cinco principales empresas de música en los mercados de grabaciones musicales en ningún Estado miembro.

104. La Comisión concluyó, por otra parte, que teniendo en cuenta las apreciaciones realizadas sobre la transparencia del mercado, la homogeneidad del producto y las represalias, «el efecto de una reducción de cinco a cuatro empresas principales tras la fusión no tendría la suficiente impor- 
tancia como para que se creara una posición de dominio colectivo de las principales empresas en los mercados de grabaciones musicales».

La Comisión se plantea, asimismo, la posible creación de una posición dominante única en los mercados de grabaciones musicales debido a la relación vertical de la empresa en participación con los intereses de Bertelsmann en el sector de los medios de comunicación. Sin embargo, entiende que las ventajas derivadas de esa integración ya están incorporadas en las cuotas de mercado de BMG en el año previo a la notificación y la empresa en participación propuesta no alcanza el umbral de la posición dominante única.

La Comisión en su detallado análisis económico incluye también el posible dominio colectivo en el mercado al por mayor de licencias para música en línea y la posible posición dominante única en los mercados de distribución de música en línea y los efectos colaterales en la edición musical para concluir que la operación propuesta no crea ni consolida una posición dominante en ninguno de los mercados analizados.

Aunque la Comisión finalmente autoriza la operación porque no alcanza la prueba que le requiere el TJCE en la jurisprudencia Airtours, una minoría del Comité consultivo está en desacuerdo con la opinión de la Comisión en cuanto a la posible creación o reforzamiento de una posición dominante colectiva en el mercado de la grabación de música y en cuanto al efecto de coordinación del comportamiento competitivo de Sony y Bertelsmann en el mercado de la edición musical.

\section{Natividad Goñi Urriza}

Caso N. ${ }^{o}$ 17. Concentraciones: Dec.Com. 15 julio 2005, Procter \& Gamble/ Gillette, M. 3732

NOTA

105. El Reglamento 139/2004, como su predecesor, está orientado a impedir la formación de estructuras de mercado anticompetitivas mediante el control de las operaciones de crecimiento externo empresarial. El núcleo del juicio de valoración de los efectos competitivos de una concentración lo constituye la creación de posiciones de poder económico, de tal modo que estarán prohibidas las operaciones que conduzcan al surgimiento o al refuerzo de una posición dominante, colectiva o individual, en el mercado común o en una parte sustancial del mismo. La posibilidad de concreción de este riesgo depende, en gran medida, del tipo de concentración proyectada. En principio, la potencialidad lesiva de las concentraciones horizontales (uniones entre empresas que, actual o potencialmente producen bienes sustitutivos) y, en menor medida, de las operaciones verticales (unión entre operadores económicos en relación de proveedor-cliente) plantea pocas 
dudas. Por el contrario, la valoración de las denominadas concentraciones conglomerales, definidas por el TPI como «uniones de empresas entre las que no existía con anterioridad a la operación una relación competitiva, ni como competidores directos ni como proveedores o clientes» (STPI 25 octubre 2002, Tetra Laval v. Comisión, párrafo 142) constituye una de las cuestiones más controvertidas del Derecho de la competencia. Mientras que en otros sistemas jurídicos, como el estadounidense, se ha abandonado, ya desde hace tiempo, prácticamente todo interés y preocupación en los efectos conglomerales de las concentraciones, en el ámbito europeo, las autoridades comunitarias han expresado reciente y repetidamente su preocupación de que, en determinados supuestos, estas operaciones puedan efectivamente dar lugar a lesiones de la competencia, mediante la formación o el refuerzo de posiciones dominantes (Coca Cola Enteprises/Amalgamated Beverages GB, M.794; Coca-Cola/Carlsberg, M.833; Guinnes/Grand Metropolitan, M. 938; Pernord Ricard/Diageo/Seagram Spirits, M. 2268; Tetra Laval/Sidel, M. 2416; General Electric/Honeywell, M. 2220).

106. En mayo de 2005, la Comisión Europea recibió la notificación del proyecto de concentración entre las multinacionales de bienes de consumo Procter \& Gamble y Gillette. El ejecutivo, siguiendo el análisis tradicional en materia de efectos horizontales (cuotas de mercado absolutas y relativas, barreras de entrada, capacidad compensatoria de los compradores, etc.), identifica determinados problemas que pueden derivarse de la operación en uno de los mercados en que ambas empresas compiten (el mercado de cepillos de dientes eléctricos), posibilitando no obstante, la resolución de los mismos mediante la adopción de una serie de compromisos de carácter estructural (desinversiones) y de conducta (concesión de licencias). Sin embargo, el principal interés de la decisión radica en que la Comisión Europea vuelve a interesarse por los posibles efectos conglomerales de una operación de concentración, concretamente, por los eventuales riesgos que para el mantenimiento de una competencia eficaz pueden derivarse de la posesión de una amplia cartera de productos o bienes pertenecientes a mercados diferenciados (a). La investigación de la Comisión se centra particularmente, en los riesgos de exclusión o cierre de mercados (foreclosure) derivados de la realización de conductas de vinculación (b) o relacionados con la posible posición de la empresa como category manager (c). Efectos excluyentes anticompetitivos que, en el caso concreto, son finalmente descartados.

107. a) En los últimos años se han desarrollado diversas teorías sobre el eventual impacto anticompetitivo de las concentraciones conglomerales que pueden ser englobadas en la ambigua y difusa categoría de efectos-cartera (portfolio-effect) o efectos-gama (range-effect). Pese a la inexistencia 
de una postura unánime sobre el alcance de este concepto, la preocupación esencial que subyace en esta teoría es que, la formación de una amplia cartera de productos puede incentivar a la empresa resultante de la concentración a llevar a cabo determinadas conductas excluyentes que acaben, a medio o largo plazo, afectando a la estructura de los distintos mercados implicados y consolidando posiciones de poder en los mismos [OCDE Competition Policy Roundtables Portfolio Effects in Conglomerate Mergers, DAFE/COMP (2002), contribución de la Comisión Europea, p. 243]. En este sentido, la combinación de las gamas de productos y marcas de las partes puede otorgar a la nueva entidad una mayor flexibilidad para estructurar sus precios, promociones y descuentos, aumentando las posibilidades de que éstos sean utilizados abusivamente. Igualmente, se incrementa el riesgo del recurso a conductas de vinculación. Finalmente, la amenaza implícita o explícita de una denegación de suministro estará más presente. Ahora bien, junto a estos eventuales efectos o peligros anticompetitivos, de la ampliación de la cartera de productos pueden, igualmente, derivarse efectos beneficiosos como consecuencia de la consecución de economías de escala y alcance en la producción y, principalmente, en la distribución conjunta de los distintos bienes integrantes de la cartera (párr. 131-133; Guinnes/Grand Metropolitan, párr. 40). La valoración de estas operaciones resulta, por tanto, compleja y plantea el delicado problema de arbitrar un criterio válido de distinción entre operaciones potencialmente lesivas de la competencia y operaciones procompetitivas. Problema que, actualmente, no se encuentra resuelto de forma satisfactoria. El ejecutivo comunitario se ha limitado a identificar una serie de factores que es preciso ponderar para determinar el impacto que estas operaciones puedan tener en la estructura competitiva del mercado (titularidad de la marca más importante o de una o más marcas importantes de un mercado determinado; cuotas de mercado de las distintas marcas, especialmente en relación con las cuotas de los competidores; importancia relativa de los distintos mercados en los que las partes disponen de cuotas y marcas significativas; el número de mercados en que el titular de la cartera dispone de la marca más importante o de una marca importante, etc.). Igualmente, la postura de las autoridades judiciales comunitarias frente a estas operaciones dista de estar definida, tal y como pone de manifiesto la comparación entre los dos pronunciamientos, hasta la fecha, del TPI en la materia (Tetra Laval v. Comisión y General Electric v. Comisión, TPI, 25 febrero 2006).

108. b) Una de las principales preocupaciones asociadas por el ejecutivo comunitario a las concentraciones conglomerales es que las mismas, mediante la ampliación de la cartera de productos de la entidad resultante de la operación, puedan facilitar la realización de conductas de vinculación 
(General Electric/Honeywell; Tetra Laval/Sidel). En primer lugar, la concentración puede facilitar a la nueva empresa el ejercicio de presión sobre sus clientes, negándose a suministrar un determinado producto (por ejemplo, las marcas más fuertes, must-stock brands) a menos que sean adquiridos a su vez otros bienes (por ejemplo, las marcas más débiles) o, incluso, todos los productos de la gama. La vinculación también puede articularse a través de incentivos en el precio. La constitución de una amplia cartera de productos complementarios otorga flexibilidad a la empresa en la fijación de sus ofertas y en la concesión de descuentos, de modo que ésta puede servirse de su capacidad financiera, para ofertar paquetes de productos a un precio más reducido que el de la suma del precio de los componentes individuales (mixed-bundling), es decir, para conceder rebajas subordinadas a la adquisición de un paquete de productos. El riesgo de efectos conglomerales anticompetitivos se condiciona a la concurrencia de al menos, dos circunstancias en la concentración proyectada. En primer lugar, la preexistencia de poder económico - no necesariamente dominante - en al menos uno de los mercados afectados y la combinación de productos comercializados en mercados vecinos o relacionados. El primer elemento es descartado, en el caso concreto, dada la competencia existente entre otros suministradores y productores y el significativo poder de compra de los distribuidores. La relación entre los mercados se refiere a la existencia de un vínculo de unión desde la perspectiva de la demanda, debido a la presencia de una base común de clientes (consumidores intermedios o finales) para los distintos productos. Base común que estará especial - si bien no exclusivamente - presente, en el supuesto de bienes complementarios. En principio, la utilización eficaz de la vinculación requiere la presencia de una relación de complementariedad entre los productos ofertados conjuntamente. Si este es el caso, presumiblemente la mayoría de los compradores de uno de los bienes deseará adquirir el otro y la oferta reducida por el paquete constituye una opción atractiva. Atractivo que puede no estar presente, sin embargo, en los casos en los que no existe relación entre las demandas de los productos. La imposición de un precio unitario puede disuadir de la compra a determinados consumidores, interesados únicamente en el producto principal.

109. c) Junto a la eventual conclusión de prácticas de vinculación, la Comisión Europea, introduce en esta decisión, una novedad en el examen de los efectos conglomerales de la concentración, al analizar, por vez primera, las posibles repercusiones competitivas de las prácticas de gestión conocidas, en su terminología anglosajona como category management. A instancia de los distribuidores, el category manager o category captain (generalmente una de las principales empresas suministradoras del sector), 
les ofrece información y recomendaciones sobre aprovisionamiento, colocación en estanterías, política de precios y técnicas de promoción. El temor existente en este caso era que, como consecuencia del refuerzo de su posición en el sector de la higiene bucal, la nueva entidad pudiera aumentar sus opciones de ser elegida category manager, y utilizara tal posición para potenciar sus propias marcas y productos, excluyendo a otros competidores del mercado. El análisis de mercado realizado, en particular, la valoración de la fuerza y posición de los distribuidores permite excluir estos riesgos e, incluso, defender el carácter generalmente beneficioso de estas prácticas, desde el punto de vista de la eficiencia económica, tanto para los distribuidores como para los consumidores.

110. En conclusión, la valoración de las concentraciones en atención a sus eventuales «efectos-cartera», no obedece a un razonamiento uniforme y consolidado, subsistiendo numerosos interrogantes que ponen de manifiesto la necesidad urgente de aprobación de las prometidas Directrices de la Comisión Europea sobre concentraciones conglomerales.

Carmen Herrero Suárez

Caso N. ${ }^{\circ}$ 18. Concentraciones: Dec.Com. 29 julio 2005, Maersk/Ponl, M. 3829

NoTA

111. La empresa danesa Maersk notificó a la Comisión Europea, el 9 junio 2005, su intención de hacerse, mediante el lanzamiento de una OPA, con la totalidad del control de la empresa neerlandesa, PONL. Ambas compañías operan principalmente, en el sector del transporte marítimo, destacando su actividad en el mercado de servicios regulares de transporte contenedorizados, en el que se encuentran en una relación de competencia directa. En una primera valoración de la operación proyectada, la Comisión consideró que de la misma podrían derivarse una serie de efectos restrictivos de la competencia, concretamente el refuerzo del carácter oligopolístico de los distintos mercados afectados y, consecuentemente, de la interdependencia entre las distintas empresas operantes en los mismos. Efectos anticompetitivos que fueron despejados, gracias a la asunción de una serie de compromisos por parte de las empresas implicadas, que permitieron al ejecutivo comunitario adoptar una decisión de compatibilidad de la concentración con el mercado común.

112. La aplicabilidad de las normas comunitarias en materia de libre competencia en el ámbito de los transportes (terrestre, aéreo y marítimo) ha estado sujeta a un régimen especial, hasta la entrada en vigor del Reglamen- 
to $1 / 2003$ del Consejo de 16 diciembre 2002, relativo a la aplicación de las normas sobre competencia previstas en el art. 81 y art. 82 del Tratado CE, en el que expresamente se reconoce la aplicación de las normas de competencia generales del Tratado al sector del transporte (considerando 36), tal y como, por otra parte, ya había venido defendiendo el TJCE. Esto no obsta a que las particulares características de estos sectores modelen o determinen necesariamente la política antimonopolio en este campo. Ello resulta especialmente evidente en el ámbito del transporte marítimo, en el que la cooperación o colaboración entre navieras ha estado tradicionalmente muy presente, debido a la integración o participación de las mismas en conferencias, consorcios y alianzas marítimas (a).

113. Los eventuales efectos lesivos de una concentración horizontal (uniones entre dos o más empresas que, actual o potencialmente, producen bienes sustitutivos) pueden manifestarse en una de las dos siguientes vertientes. En primer lugar, las concentraciones entre competidores pueden dar lugar a la formación de posiciones de dominio unilaterales, como consecuencia de la unión de la potencia económica de las empresas que se concentran. En segundo lugar, la operación puede producir los denominados por la Comisión Europea, «efectos de coordinación», al conducir a un refuerzo de estructuras de mercado oligopolísiticas, posibilitando el surgimiento de posiciones dominantes colectivas (b).

114. a) La configuración de una política en materia de libre competencia en el ámbito del transporte marítimo ha estado marcada por la difícil tarea de conciliar las reglas orientadas a la prohibición de acuerdos colusorios, abuso de posición de dominio y control de la concentración empresarial con instituciones tradicionales, de gran difusión en el tráfico marítimo, como las conferencias y los consorcios marítimos.

115. Las conferencias son cárteles ortodoxos entre navieras, cuyo objeto es eliminar la competencia efectiva entre sus miembros, actuando fundamentalmente sobre los precios y la capacidad. Determinados acuerdos adoptados en el seno de las conferencias marítimas se encuentran exentos de la prohibición del art. 81.1 del Tratado CE en virtud del Reglamento del Consejo 4056/86, quien las define como «un grupo de dos o más transportistas armadores que preste servicios internacionales regulares para el transporte de mercancías siguiendo una o más líneas determinadas dentro de unos límites geográficos específicos y que ha concluido un acuerdo o trato, cualquiera que sea su naturaleza, en cuyo marco dichos transportistas operan conforme a fletes uniformes o comunes y a todas las demás condiciones de transporte establecidas para la prestación de servicios regulares». Los consorcios son acuerdos operativos entre navieras orientados a la ex- 
plotación conjunta de un servicio de transporte marítimo (generalmente, contenedorizado), de tal forma que se posibilite una racionalización del servicio y una reducción de los costes de sus miembros. A diferencia de las conferencias, por tanto, los consorcios no influyen, al menos de forma directa, en la fijación de los precios, sin perjuicio de la existencia de una cooperación intensa entre sus miembros. Cooperación que se encuentra exenta de la prohibición general de acuerdos restrictivos por el Reglamento de la Comisión 823/2000, recientemente reformado por el Reglamento 611/2005.

116. Pese a la exención por categorías de la que gozan tanto las conferencias como los consorcios marítimos, su presencia y posición en los mercados han de ser tenidos en consideración, tanto en lo que respecta a la aplicación del art. 82 del Tratado CE que sanciona los abusos de posición dominante (vid. ORTIZ/CABRERA/SOPEÑA: «Las normas de competencia comunitarias en el transporte», en AA.VV.: Tratado de Derecho de la Competencia, coords. BENEYTO/MAILlo, Barcelona, 2005, pp.1716 y ss.) como en materia de control de la concentración empresarial. En este último aspecto, la Comisión ha reiterado en diversas decisiones la necesidad, al evaluar los efectos de una concentración en el transporte marítimo regular, de tomar en consideración la pertenencia de las empresas que se concentran a las conferencias y consorcios marítimos existentes en los mercados afectados (Dec.Com. 19 diciembre 1996, P\&O/Royal Nedlloyd, M. 831; Dec.Com. 7 mayo 1999, Maersk/Safmarine, M. 1474; Dec.Com. 6 octubre 1999, Maersk/Sealand, M. 1651). Los efectos de una concentración en el transporte de línea regular dependen así no sólo del poder de mercado de las empresas que se concentran, expresado en cuotas de mercado, sino también de los lazos contractuales que les unen a otras navieras con las que participan en conferencias y consorcios. Política que es reiterada en el caso objeto de examen.

117. b) El art. 2.3 del Reglamento 139/2004 establece la incompatibilidad con el mercado común de las concentraciones que sean «susceptibles de obstaculizar de forma significativa la competencia efectiva en el mercado común o en una parte sustancial del mismo, en particular como consecuencia de la creación o refuerzo de una posición dominante». El núcleo del juicio de valoración de los efectos de una concentración sobre la competencia lo constituye el refuerzo o creación de una posición dominante. Este concepto hace referencia a «una situación de poder económico en que se encuentran una o varias empresas y que les permite impedir que haya una competencia efectiva en el mercado de que se trate, confiriéndoles la posibilidad de comportarse con un grado apreciable de independencia frente a sus competidores, sus clientes y, finalmente, los consumidores» (Directrices en materia de concentraciones horizontales, párrafo 2). Esta 
noción abarca tanto los supuestos de dominio unilateral como los casos de posición dominante colectiva. En consecuencia, los efectos lesivos de la competencia de una concentración entre competidores pueden deberse, no a la formación de posiciones de dominio individuales, sino a la creación o refuerzo de una estructura de mercado oligopolística anticompetitiva. Ahora bien, en el caso de las posiciones dominantes colectivas la cuestión que se plantea no es la simple creación de un oligopolio, sino la creación de un oligopolio en un mercado cuyas especiales características permiten augurar que a las distintas empresas que operan en el mismo les resultaba más rentable coordinar sus políticas empresariales que competir. Las Directrices de la Comisión en materia de concentraciones horizontales, inspiradas en las Merger Guidelines estadounidenses, recogen las principales aportaciones de la teoría económica y de la jurisprudencia de los tribunales de justicia (STPI 6 junio 2002, Airtours/First Choice, T-342/99) en el establecimiento de los elementos que integran el concepto de posición dominante colectiva, y de las circunstancias y factores que han de ser especialmente tenidos en cuenta para aventurar si una operación puede dar lugar a la aparición o no de este tipo particular de situaciones de poder en el mercado (párrafos 37 a 57). En concreto, se insiste en que, las posiciones dominantes colectivas constituyen un tipo cualificado de oligopolio, en el que las empresas están en condiciones de adoptar conductas paralelas o coordinadas. No basta, por tanto, con la existencia de un elevado índice de concentración en el mercado. Es necesario analizar los caracteres del mercado (naturaleza de la demanda, grado de transparencia, estructura de costes de los productores, grado de diferenciación entre los productos, etc.) a fin de determinar si en él se cumplen los requisitos de una coordinación sostenible (posibilidad de llegar a un acuerdo en los términos de cooperación, vigilancia frente a posibles incumplidores y existencia de mecanismos creíbles de disuasión).

118. En el caso concreto, la Comisión Europea, si bien no realiza un análisis exhaustivo sobre los extremos apuntados, identifica como principal peligro de la operación proyectada un refuerzo del carácter oligopolístico del mercado de línea de transporte regular contenedorizado, ya de por sí bastante concentrado, y de los lazos y relaciones entre los distintos agentes operantes en el mismo. Refuerzo debido, principalmente, al incremento de los vínculos entre la entidad resultante de la operación y las diversas conferencias y consorcios marítimos presentes en las diversas travesías o rutas. La asunción de una serie de compromisos por parte de las empresas implicadas, entre los que destaca el abandono o retirada de PONL de una serie de conferencias y consorcios son considerados suficientes por el ejecutivo comunitario para eliminar los riesgos de coordinación o actuación paralela en los mercados relevantes. 
Caso N. ${ }^{\circ}$ 19. Concentraciones: STJCE 15 febrero 2005, Tetra Laval, C-12/03P, Rec., p. I-1113.

NoTA

119. En el presente asunto, la Comisión recurrió en casación contra la STPI 25 octubre 2002, Tetra Laval/Comisión, T-5/02, Rec. 2002, p. II-4381, sentencia que anuló la Decisión de aquélla de prohibir la concentración de Tetra Laval con Sidel (Dec.Com. 30 octubre 2001, DO L 43 de 13 febrero 2004).

120. Tetra Laval, en el momento de los hechos, era la empresa líder en el mercado de los envases de cartón. Sidel, por su parte, ocupaba una posición destacada en el sector de las máquinas estiradoras-sopladoras con las que se realizan los embalajes de plástico PET (polietileno tereftalato).

Los llamados productos sensibles - la leche y los productos lácteos, los zumos y néctares de fruta, las bebidas sin gas con sabor a fruta y las bebidas a base de té o de café - , en determinados casos, requieren estar envasados en recipientes que impidan el paso de la luz y del oxígeno. El cartón es el material adecuado para envasar este tipo de productos; sin embargo, en relación con el PET, si bien al ser una resina porosa deja pasar el oxígeno y la luz, se están desarrollando tratamientos de barrera que permiten proteger de estos elementos a los productos sensibles antes mencionados. Sidel trabajaba en los tratamientos de barrera para el PET, por esta razón, la Comisión entendió que debía impedir la concentración propuesta, ya que, con la unión de ambas empresas, la nueva entidad consolidaría su posición de dominio en el mercado de cartón y, por presumibles prácticas de apalancamiento - ventas acopladas, precios predatorios, rebajas por fidelidad-, adquiriría una posición dominante en el mercado del PET.

121. La concentración de Tetra y Sidel fue analizada por la Comisión $\mathrm{y}$, posteriormente, por los órganos judiciales comunitarios, en el marco del Reglamento (CEE) n. ${ }^{\circ}$ 4064/1989 del Consejo, de 21 diciembre 1989, sobre el control de las operaciones de concentración de empresas ( $D O$ L 395 de 21 septiembre 1990) - norma actualmente derogada por el Reglamento (CE) n. ${ }^{\circ}$ 139/2004 del Consejo, 20 enero 2004, sobre el control de las concentraciones entre empresas (DOUE L 24 de 29 enero 2004)-.

122. Las conclusiones a destacar que resolvió el Tribunal de Justicia fueron las siguientes: a) la Comisión debe aportar «pruebas sólidas» para poder prohibir la concentración de Tetra con Sidel; b) la Decisión de la Comisión de prohibir la concentración se basaba en que la unión lesionará la competencia debido a previsibles comportamientos ilícitos de la nueva entidad. Precisamente la ilicitud de dichas actuaciones debe ser tenida en cuenta por 
la Comisión para, al menos, poder dudar de que dichas actuaciones vayan a consumarse con toda probabilidad; c) la Comisión debe considerar, también, los compromisos asumidos por las partes para poder entender que la concentración, quizá, no lesionará la competencia en el mercado común.

123. a) Exigencia probatoria: Concentración de tipo conglomerado. La concentración puede suponer la unión de empresas que actúan en el mismo mercado - concentración horizontal-, en mercados de distintos niveles de la cadena de valor - concentración vertical - o en mercados conexos - concentración de tipo conglomerado-. Este último tipo de concentración es objeto del caso (sobre las concentraciones conglomerales [Konglomerate Zusammenschlüsse], vid., ad ex., E. ZEISE, «Wettbewerbliche Beurteilung», en J.L. SCHUlte [Hrsg.], Handbuch Fusionskontrolle, München, 2005, pp. 343 y ss., concr. pp. 377-379).

Respecto a lo que debe entenderse, más exactamente, por concentración de tipo conglomerado, el Tribunal de Justicia reprodujo la definición que aportó el TPI en la sentencia recurrida, y recogió, de este modo, que se trata de una «concentración de empresas entre las que no existían antes, en lo esencial, relaciones de competencia, ya fuera como competidores directos, ya como proveedores y clientes, concentración que no da lugar a auténticas superposiciones horizontales entre las actividades de las empresas que se concentran ni a relaciones verticales entre ellas, en el sentido estricto del concepto, de modo que no cabe presumir con carácter general que produzcan efectos contrarios a la competencia» (apartado 22).

124. El asunto Tetra/Sidel pone de manifiesto la diferencia entre concentraciones lesivas de la competencia por dar lugar, directa e inmediatamente, a un cambio de la estructura del mercado, y aquellas otras que requieren de un comportamiento posterior por parte de la nueva entidad para poder lesionar la competencia. El caso Tetra/Sidel es un ejemplo de este segundo tipo de unión.

Si bien, en muchos casos, las concentraciones horizontales suelen llevar aparejados efectos estructurales, así como, las concentraciones no horizontales suelen desplegar efectos de comportamiento, no deberían asumirse automáticamente este tipo de consecuencias respecto de los distintos supuestos de concentración. En efecto, ad ex., en una concentración de conglomerado en la que la nueva entidad dispone de la totalidad del input necesario para fabricar un determinado producto, impidiendo con ello que sus competidores puedan producir este mismo bien, es una concentración no horizontal que supone un cambio directo e inmediato de la estructura del mercado, y que lesiona, por tanto, de forma automática la competencia (G. DRAUZ, «Conglomerate and vertical mergers in the light of the Tetra Judgement», Competition Policy Newsletter, n. ${ }^{\circ} 2$, 2005, p. 37). 
125. La diferencia entre concentraciones con efectos estructurales y concentraciones con efectos de comportamiento lleva a exigir distinta dificultad en la prueba - algunos autores consideran que el control de la prueba que debe hacer el órgano judicial es diferente en función al tipo de concentración de que se trate y, en concreto, entienden que el Tribunal de Justicia, precisamente en el asunto Tetra/Sidel, sugiere que el nivel de prueba exigible es inversamente proporcional al grado de consenso de la teoría económica aducida (E. DE LA SERRE/J. PeYre, «Le côntrole du juge communautaire sur les décisions d'incompatibilité en matière de contrôle des concentrations: quelques perspectives ouvertes par les arrêts Schneider et Tetra Laval», La semaine juridique entreprise et affaires, n. ${ }^{\circ}$ 3, 2003, p. 6) - . Así, respecto de las primeras es más sencillo probar si la concentración va a lesionar la competencia a la hora de tomar una decisión sobre su admisión. En cambio, cuando se trata de una concentración de conglomerado, como la del caso Tetra/Sidel, en la que no hay cambios estructurales - al menos sustanciales - , decidir prohibir dicha unión es una labor difícil debido a lo complicado de probar que la nueva entidad va a llevar a cabo determinados comportamientos de apalancamiento lesivos de la competencia. En palabras del Tribunal de Justicia, «el análisis de una concentración de tipo conglomerado es un análisis prospectivo en el cual la consideración de un lapso de tiempo proyectado hacia el futuro, por un lado, y el apalancamiento necesario para que exista un obstáculo significativo para la competencia efectiva, por otro, implican que las relaciones de causa a efecto no se perciben con nitidez, adolecen de incertidumbre y son difíciles de determinar» (apartado 44).

Precisamente, uno de los motivos alegados por la Comisión en su recurso de casación fue el hecho de que el TPI le exigiera que avalase con «pruebas sólidas» su Decisión de impedir la concentración Tetra/Sidel, a diferencia de lo que había exigido en otros casos de concentraciones como el asunto Gencor - concentración con cambio de estructura del mercado afectado (STPI de 25 marzo 1999, Gencor/Comisión, T-102/96, Rec., p. II-753) - . Al efecto, el Tribunal de Justicia señaló que, «en cuanto al argumento basado en la modificación del criterio del TPI en relación con el seguido en la sentencia Gencor/Comisión, antes citada, procede señalar que, contrariamente a lo que sostiene la Comisión, el TPI no se ha desviado de la posición que recogió en el apartado 94 de aquella sentencia, posición según la cual existe un obstáculo significativo para la competencia efectiva en la medida en que se modifica de manera duradera la estructura de los mercados afectados cuando una concentración tiene como consecuencia directa e inmediata la creación de condiciones que hacen posibles y económicamente racionales los comportamientos abusivos». «A este respecto, es preciso señalar que la situación en el asunto que dio lugar a la sentencia Gencor/Comisión, antes citada, era 
totalmente distinta de la contemplada en la Decisión impugnada. Según se afirma en el apartado 91 de aquella sentencia, el resultado de la operación habría sido la creación de una posición dominante duopolística en los mercados del platino y del rodio, que habría supuesto un obstáculo significativo para la competencia efectiva en el mercado común: «Por lo tanto, la operación de concentración es lo que habría modificado de manera duradera la estructura de los mercados afectados en aquel asunto, haciendo de este modo posibles y económicamente racionales los comportamientos abusivos». «En el caso de autos, es verdad que la concentración notificada podía modificar ligeramente la estructura del mercado del cartón, en la medida en que la nueva entidad podía reforzar la posición dominante que desde hacía mucho tiempo Tetra ocupaba en dicho mercado, posición que, por lo demás, había sido objeto de una decisión de la Comisión con arreglo al art. 82 CE. Sin embargo, lo que la Comisión pretendía proteger al prohibir la referida concentración no era tanto la competencia efectiva en el mercado del cartón como la competencia en el mercado de los equipos para envasado en PET, concretamente en el de las máquina estiradoras-sopladoras de baja y de alta capacidad utilizadas para los productos sensibles» (apartados 79, 80, 81 y 82).

126. Exigencia probatoria: Pruebas sólidas. La Comisión consideró que la concentración iba a consolidar una posición dominante en el mercado del cartón - que ya tenía Tetra Laval-, e iba a suponer una posición dominante en el mercado del PET por el efecto palanca. El apalancamiento se produciría por la realización de comportamientos abusivos de Tetra/Sidel en el mercado del cartón, que afectarían al mercado del PET, apareciendo entonces la nueva entidad como sujeto con posición de dominio también en el mercado conexo del PET.

«Según la Comisión, la operación de concentración notificada puede incitar a Tetra a valerse, mediante la práctica de un apalancamiento, de su posición dominante en el mercado de equipos y de productos consumibles relativos a envases de cartón para persuadir a sus clientes en dicho mercado que se pasen al PET para el envasado de ciertos productos sensibles de que opten por las máquinas estiradoras-sopladoras de Sidel, excluyendo de este modo a los competidores mucho más pequeños y transformando en posición dominante el liderazgo de Sidel en el mercado de las máquinas estiradoras-sopladoras para productos sensibles. Esta conducta de Tetra resulta favorecida por su relación estrecha y continuada con sus clientes, su capacidad financiera y su know-how, así como su prestigio en el sector aséptico y ultralimpio, la fortaleza, la tecnología y la reputación de calidad que caracterizan actualmente a Sidel y la situación de integración vertical de que se beneficiará la entidad que surja de la concentración notificada (en lo sucesivo «nueva entidad») en lo que atañe a tres sistemas de envasado (cartón, PET y PEAD)» (apartado 9). 
127. El Tribunal de Justicia afirmó que la Comisión tiene margen de apreciación en relación con cuestiones económicas y fácticas, y reconoció, además, lo complicado de la labor probatoria cuando se trata de análisis de futuro o prospectivos. Sin embargo, consideró que, sin perjuicio del margen de apreciación del que dispone la Comisión, el juez comunitario también puede controlar las pruebas aportadas para comprobar si realmente avalan la Decisión adoptada. Exactamente dispuso lo siguiente: «En este contexto [concentración de conglomerado que necesita de un análisis prospectivo], es sumamente importante la calidad de las pruebas que presenta la Comisión para acreditar la necesidad de una decisión que declare la operación de concentración incompatible con el mercado común, puesto que tales pruebas deben confirmar las apreciaciones de la Comisión según las cuales, de no adoptarse una decisión de ese tipo, resultaría plausible una evolución económica como la que sirve de base a dicha institución» (apartado 44).

128. Si bien, con carácter general, las afirmaciones del Tribunal de Justicia deben ser tenidas en cuenta, en el caso concreto de Tetra/Sidel, siguiendo al Abogado General Antonio Tizzano, el TPI cometió diversos errores a la hora de valorar las pruebas aportadas por la Comisión. Así, respecto de la conclusión de la Comisión sobre el aumento de la utilización del envase de PET para la leche UHT, el TPI afirmó que el consumo del PET para la leche UHT no iba a aumentar. Con esta toma de posición del juez comunitario, el Abogado General entendió que el «Tribunal de Primera Instancia sustituyó erróneamente el punto de vista de la Comisión por el suyo propio, formulando una previsión autónoma sobre la evolución futura del mercado» (apartado 93 de las Conclusiones del Abogado General Sr. Antonio Tizzano presentadas el 25 mayo 2004). En cuanto a las estimaciones de la Comisión sobre el crecimiento del consumo de PET respecto del envasado de leche fresca (10\%-15\%), así como de leche aromatizada y bebidas a base de leche (25\%), el TPI manifestó que no son, en efecto, muy convincentes; afirmación que, consideró el Abogado General, «adolece de una valoración incompleta y errónea de los elementos relevantes y, además no está adecuadamente motivada» (apartado 96 de las Conclusiones). Por lo que respecta a la determinación de la Comisión sobre el desplazamiento del PEAD por parte del PET en el envasado de leche fresca, el Abogado General dispuso que, «como ha subrayado acertadamente la Comisión, el TPI llegó efectivamente a tal conclusión sin criticar en modo alguno, e incluso sin mencionar siquiera, las valoraciones que aquella institución había llevado a cabo - basándose en los resultados de su estudio de mercado y en las indicaciones procedentes de estudios independientes - sobre las ventajas competitivas del PET en relación con el PEAD» (apartado 99 de las Conclusiones). 
Junto a estos errores del TPI, el Abogado General, contrariamente a lo que dispuso la Comisión, estimó fundada la afirmación del TPI, en virtud a la cual, la Comisión no aportó ningún análisis del mercado de vidrio a la hora de concluir que el uso del PET iba a crecer en el envasado de zumos, como consecuencia de la previsible sustitución del envase de vidrio por el de PET (apartado 105 de las Conclusiones).

129. b) Análisis de los futuros comportamientos abusivos por parte de la nueva entidad: Conclusión del Tribunal de Justicia. El Tribunal de Justicia refrendó la postura adoptada por el TPI, al menos en lo que se refiere al control teórico que puede realizar el órgano judicial respecto de una Decisión de la Comisión. Sin embargo, en relación con los previsibles comportamientos abusivos por parte de Tetra/Sidel, el Tribunal de Justicia entendió que el grado probatorio exigido por el TPI a la Comisión fue excesivo.

En efecto, el Tribunal de Justicia afirmó que «(...) resultaría contrario al objetivo de prevención del Reglamento exigir a la Comisión que analice, respecto de cada proyecto de concentración, en qué medida los incentivos para la adopción de comportamientos contrarios a la competencia podrían verse reducidos, o incluso eliminados, como consecuencia de la ilegalidad de dichos comportamientos, de la posibilidad de que sean descubiertos y reprimidos por las autoridades competentes, tanto a nivel comunitario como nacional, y de las sanciones pecuniarias que podrían acarrear» (apartado 75). Parece que el Tribunal estimó que la Comisión debería haber tenido en cuenta la ilicitud de los presumibles comportamientos de la nueva entidad para tomar su Decisión; sin embargo, el grado de análisis exigido por el TPI al respecto lo consideró exagerado (L. PETRE/A. NuCARA, «Standard of proof and scope of judicial review in EC merger cases: everything clear after Tetra Laval?», Eur.Compet.L.Rev., vol. 26, n. ${ }^{\circ}$ 12, December 2005, p. 702). Este error de Derecho apreciado por el Tribunal de Justicia no cambió, sin embargo, el fallo de la sentencia del TPI, ya que, la anulación de la Decisión de la Comisión estaba fundamentada, en particular, en el hecho de que ésta no tuvo en cuenta los compromisos asumidos por las partes de la concentración para evitar lesionar la competencia.

130. A los concretos comportamientos abusivos por parte de la nueva entidad la Comisión hizo referencia de esta manera: «Al utilizar su posición dominante en el mercado del cartón aséptico de varias maneras, Tetra/ Sidel podría llegar a marginar a sus competidores y a dominar el mercado de los equipamientos PET, en particular, el de las sopladoras de preformas. Tetra/Sidel tendría la posibilidad de vincular las ventas de equipamientos y productos fungibles para el envasado en cartón con las ventas de equipamientos para el envasado en PET y eventualmente también de preformas (en particular, las preformas tratadas con la tecnología de barrera). Tetra/ 
Sidel podría también recurrir a presiones o a medidas de incentivos (como precios depredadores, guerra de precios y descuentos de fidelidad) para que sus clientes de cartón compren equipamientos de PET y, eventualmente, preformas a Tetra/Sidel y no a sus competidores o empresas de transformación» (Dec.Com. 30 octubre 2001, Tetra Laval/Sidel, DO L 43 de 13 febrero 2004, apartado 364).

131. Análisis de los futuros comportamientos abusivos por parte de la nueva entidad: Relación entre los Reglamentos de concentraciones 4064/1989 y 139/2004. La incompatibilidad de las concentraciones con el mercado común y, consecuentemente, su ilicitud, viene definida en los artículos 2.2 y 2.3 de los Reglamentos comunitarios de concentraciones - el ya derogado n. ${ }^{\circ} 4064 / 1989$, y el actualmente en vigor n. ${ }^{\circ} 139 / 2004-$. Si bien el texto normativo aplicable a los efectos de resolver el caso Tetra/Sidel fue la norma de 1989, es interesante analizar la importante diferencia de regulación recogida en los dos Reglamentos.

132. En virtud al Reglamento 4064/1989, la concentración que suponga un obstáculo para una competencia efectiva en una parte sustancial del mercado comunitario será declarada incompatible con el mercado común, si dicho obstáculo viene determinado por la creación o el reforzamiento de una posición dominante consecuencia de la concentración. Sin embargo, en el Reglamento 139/2004, lo importante es la lesión de la competencia en una parte sustancial del mercado comunitario (substantial impediment to effective competition [SIEC]), con independencia de que dicho efecto lesivo venga determinado por la creación o el reforzamiento de una posición dominante (para dos magníficas síntesis de lo que este cambio supone, vid., ad ex., M. Baron, «VO Nr. 139/2004 [FKVO]», en Langen/Bunte, Kommentar zum deutschen und europäischen Kartellrecht, vol. 2 [Europäisches Kartellrecht], 10. ${ }^{a}$ ed., München, 2006, pp. 880-885, y C. Herrero Suárez, "Control de las concentraciones de empresas», en L.A. Velasco San Pedro [Coord.], Derecho europeo de la competencia. Antitrust e intervenciones públicas, Valladolid, 2005, pp. 464-472). Por tanto, con el primer Reglamento, si una concentración supone un obstáculo significativo para la competencia efectiva en una parte sustancial del mercado común, sólo será prohibida si la nueva entidad posee una posición dominante en el mercado comunitario; si no es así, debería admitirse. En cambio, la misma concentración descrita, en el marco de aplicación del Reglamento 139/2004, siempre, esto es, ya cree o refuerce una posición dominante en el mercado comunitario, ya no la cree ni la refuerce, debería ser declarada incompatible con el mercado común (K. Pieters, «Comissión versus Tetra Laval: another defeat for the European Comissión», European Law Reporter, n. ${ }^{\circ} 4$, april 2005, p. 155). 
133. Con el nuevo tenor del artículo 2.2 del Reglamento 139/2004 - también 2.3 , en sentido contrario-, no debería caber la duda de si el control de determinadas concentraciones debe hacerse a priori - determinando su prohibición, si es el caso- o a posteriori - determinando su admisión, con la posibilidad de aplicar el artículo 82 TCE en un futuro-. En efecto, tal como se planteó en el caso Tetra/Sidel, las concentraciones que no dan lugar de forma directa e inmediata a un cambio en la estructura del mercado - ad ex., asunto Tetra/Sidel-, necesitarían de comportamientos futuros por parte de la nueva entidad para poder lesionar la competencia. En el caso de estudio, los comportamientos presumibles tenían carácter anticompetitivo, puesto que eran actuaciones constitutivas de abuso de posición dominante. Por ello, se planteó en el asunto si las concentraciones de este tipo debían ser controladas ex ante, mediante la decisión de impedir su realización por previsibles lesiones de la competencia, o si, por el contrario, deberían gozar de la presunción de legalidad, y, en el momento en que se llevaran a cabo esos comportamientos abusivos, se debía actuar a través del artículo 82 TCE para reprimir y castigar la conducta.

Con el nuevo Reglamento no tendría que plantearse siempre, en este tipo de concentraciones, si procede el control ex ante o el ex post, ya que, las concentraciones declaradas incompatibles con el mercado común no tienen que derivar necesariamente en una posición dominante, creada o reforzada, por parte de la nueva entidad.

134. Análisis de los futuros comportamientos abusivos por parte de la nueva entidad: Relación entre el Reglamento de concentraciones y el artículo 82 TCE. Tal como resolvió el recurso el TPI, parece que, como afirmó la Comisión, existe una presunción de legalidad de las concentraciones, debido a que, si no se puede probar con total probabilidad que la concentración no va a suponer un obstáculo significativo para la competencia en el mercado común, dicha unión debería permitirse, puesto que, en un momento ex post, en el supuesto de que la nueva entidad lesione la competencia con sus actuaciones se podría aplicar el artículo 82 TCE.

Una de las diferencias entre el régimen jurídico de las concentraciones y el del abuso de posición de dominio radica en el carácter, preventivo del primero y represivo del segundo. Así, el artículo 82 TCE castiga el abuso de posición dominante; sin embargo, cuando se trata de una concentración, la regulación comunitaria pretende evitar que se produzca dicha lesión de la competencia. En las concentraciones de tipo conglomerado, ad ex., si los comportamientos posteriores de la nueva entidad pueden ser reprimidos por la aplicación del artículo 82 TCE - por ser abusivos de una posición de dominio-, podría ser demasiado gravoso cuestionarse si la concentración debe ser admitida o no, directamente se podría considerar válida y, después, 
si ocurren esos comportamientos ilícitos, se aplicaría el artículo 82 TCE. El control ex ante de estas concentraciones dejaría de tener sentido para actuar en un momento ex post con la aplicación, si es el caso, del artículo 82 TCE (C. Prieto, Clunet, pp. 449-450).

135. La anterior conclusión, que constituye una crítica por parte de la Comisión a las exigencias de los órganos judiciales comunitarios, se podría entender como un principio de actuación en materia de concentraciones. En efecto, tal como dispone el Abogado General Antonio Tizzano, el control que la Comisión debe hacer para considerar compatible una concentración que no supone un obstáculo significativo a la competencia en el mercado común, por crear o reforzar una posición de dominio (art. 2.2 R 4064/89), es simétrico al que debe hacer para estimar lo contrario - incompatible la concentración proyectada por ser lesiva de la competencia (art. 2.3 R 4064/89) - . Sin embargo, no siempre será claro determinar uno y otro extremo: Habrá muchos supuestos grises sobre los que la Comisión no pueda concluir sin ninguna duda que la concentración es compatible o no lo es, y, en esta zona gris, debería prevalecer la presunción de legalidad (apartados 75-77 de las Conclusiones). Confirma esta conclusión el propio Reglamento 4064/1989; en virtud al cual, la falta de respuesta de la Comisión ante una concentración notificada debe estimarse en sentido positivo (art. 10.6). De todo lo anterior podría deducirse que el nivel probatorio exigido para prohibir una concentración es superior al establecido para permitirla (L. PETRE/A. NUCARA, «Standard of proof and scope of judicial review in EC merger cases: everything clear after Tetra Laval?», Eur.Compet.L.Rev., vol. 26, n. ${ }^{\circ} 12$, december 2005, p. 698).

136. En sentido contrario, otros autores consideran que el Tribunal de Justicia sostiene que el Reglamento de concentraciones contiene un principio de neutralidad respecto de la admisión y prohibición de las concentraciones (M. F. BAY/J. RUIZ CALZADO, «Tetra Laval II: the coming of age of the judicial review of merger decisions», World Compet., vol. 28, n. ${ }^{\circ} 4$, december 2005, pp. 447-449). Los argumentos que aportan para justificar su tesis son éstos:

1. ${ }^{\circ}$ Entienden que el Tribunal de Justicia confirmó la existencia de dicho principio de neutralidad, al recoger en el apartado 43 que «(...) el análisis prospectivo consiste en examinar de qué modo podría una operación de concentración modificar los factores que determinan la situación de la competencia en un mercado dado, a fin de verificar si dicha operación supondría un obstáculo significativo para una competencia efectiva. Un análisis de este tipo requiere imaginar las diversas relaciones de causa a efecto posibles, para dar prioridad a aquellas cuya probabilidad sea mayor». De 
este modo, sostienen estos autores, la Comisión prohibirá o admitirá la concentración según si el escenario más probable restringe la competencia o no.

2..$^{\circ}$ En segundo lugar, el Tribunal de Justicia, ya en 1998, hizo hincapié en las circunstancias del caso concreto como elemento clave para determinar admitir o prohibir una concentración: «Una medida de este tipo [análisis prospectivo del mercado de referencia] requiere un atento examen de las circunstancias que, según cada caso concreto, resulten pertinentes para apreciar los efectos de la operación de concentración sobre el juego de la competencia en el mercado de referencia» (STJCE 31 marzo 1998, Kali\&Salz, asuntos acumulados C-68/94 y C-30/95, Rec., p. I-1375, apartado 222).

3. ${ }^{\circ}$ El tercer argumento lo encuentran en otras sentencias del TPI en las que el órgano judicial comunitario insistió en la necesidad de tener en cuenta el mismo estándar legal de prueba, sin distinguir según se trate de una Decisión de la Comisión positiva o negativa:

a) «Por lo que se refiere, en segundo lugar, a la imputación basada en un error de apreciación en cuanto al acceso privilegiado a las grandes empresas de distribución que $\mathrm{P} \& \mathrm{G}$ obtendría en virtud de la operación, este TPI considera que, en las circunstancias del caso de autos, tal argumento no puede demostrar que la concentración diera lugar a la creación de una posición dominante en el mercado de referencia. En efecto, a la vista de la escasa dimensión de las cuotas de mercado de las marcas secundarias de VPS - Blümia y Femina - y de la de los productos fabricados por VPS por cuenta de distribuidores, carece de fundamento la escueta alegación de que, gracias a su adquisición, $\mathrm{P} \& \mathrm{G}$ podría impedir el acceso de competidores a las grandes empresas de distribución. Por otra parte, la demandante no facilita dato alguno que permita fundamentar la alegación según la cual $\mathrm{P} \& \mathrm{G}$ podría proponer a los distribuidores sustituir los productos Camelia por productos distintos de Camelia, máxime cuando, en su Decisión, la Comisión demostró que el mercado de compresas se caracterizaba por la fidelidad de las consumidoras a la marca, especialmente en el segmento de los productos de gama superior (apartados 97 y 125 de la Decisión). De lo anterior se deduce que debe rechazarse esta imputación de la demandante, así como el argumento basado en que la Comisión favoreció el futuro debilitamiento de la marca Camelia al autorizar la fragmentación de las actividades de VPS, lo cual no constituye sino una mera hipótesis» (STPI 
27 noviembre 1997, Kaysersberg v. Comisión, T-290/94, Rec. 1997, p. II-2137, apartado 178).

b) «En segundo lugar, la Comisión no demostró suficientemente el fundamento de la alegación según la cual cualquier intento de comportamiento contrario a la competencia en los mercados dominados sería castigado con una reducción de las compras de productos de SEB-Moulinex en los demás mercados» (...) «De lo anterior se desprende que la Comisión no ha demostrado suficientemente el fundamento de su teoría del efecto gama tal como lo invoca para justificar la inexistencia de serias dudas en los países no cubiertos por los compromisos» (STPI 3 abril 2003, Babyliss v. Comisión, T-114/02, Rec. 2003, p. II-1279, apartados 356 y 363 , respectivamente).

137. No obstante todo lo dicho, tratar de forma intercambiable los dos remedios posibles - la prohibición de la concentración a priori o la aplicación del artículo 82 TCE a posteriori- puede no ser lo más adecuado. Por una parte, no puede ser entendido del mismo modo, evitar la lesión de la competencia mediante la prohibición de la concentración, que castigar la efectiva lesión a través del artículo 82 TCE. Por otra parte, limitar la actuación de las empresas en el mercado común, impidiendo con carácter preventivo su crecimiento, podría lesionar la libre competencia entendida en un sentido económico (en este sentido de tener en cuenta la libertad de empresa, L. Petre/A. NuCARA, «Standard of proof and scope of judicial review in EC merger cases: everything clear after Tetra Laval?», Eur.Compet.L.Rev., vol. 26, n. ${ }^{\circ}$ 12, December 2005, p. 698; M. F. BAY/J. RUIZ CALZADO, «Tetra Laval II: the coming of age of the judicial review of merger decisions», World Compet., vol. 28, n. ${ }^{\circ} 4$, december 2005, p. 450).

Estos dos intereses - evitar la lesión de la competencia y favorecer el desarrollo económico de las empresas - son los que deberían estar en juego a la hora de decidir cómo actuar. Habría que tener en cuenta, además, que, si prevalece el segundo, imponer una sanción a la nueva entidad por haber abusado de su posición de dominio podría no prevenir futuras actuaciones lesivas de la competencia. En efecto, la multa que deben pagar las empresas infractoras en virtud a los arts. 81 y 82 TCE, no puede ser superior, en ningún caso, al $10 \%$ del volumen de negocio del ejercicio precedente de cada entidad, con lo cual, cabría la posibilidad de que a la nueva entidad le resultara más rentable restringir la competencia que actuar respetando las normas (Directrices para el cálculo de las multas impuestas en aplicación del apartado 2 del artículo 15 del Reglamento n. ${ }^{\circ} 17 \mathrm{y}$ del apartado 5 del artículo 65 del Tratado CECA, DO C 9 de 14 enero 1998). 
138. c) Compromisos asumidos por las partes de la concentración. Tetra y Sidel asumieron una serie de compromisos para que la concentración no supusiera una lesión de la competencia. En concreto, Tetra propuso estos compromisos: «(...) mantener separados a Tetra y a Sidel durante diez años, el de no hacer ofertas que versen a la vez sobre productos de cartón y sobre máquinas estiradoras-sopladoras fabricadas por Sidel y el de cumplir las obligaciones que le incumben en virtud de la Decisión 92/163/CEE de la Comisión, de 24 de julio de 1991, relativa a un procedimiento de aplicación del artículo 86 del Tratado CEE» (apartado 11).

139. Ninguno de los dos Reglamentos de concentraciones - el ya derogado 4064/1989, y el actualmente en vigor 139/2004 - recogen la obligación de tener en cuenta los compromisos asumidos por las partes. La Comisión no tiene esa obligación; pero sí puede imponer condiciones o cargas a las partes para que cumplan los compromisos asumidos por ellas, con el fin de poder declarar compatible la concentración con el mercado común (art. 8.2 de ambos textos) (para una visión de conjunto de la práctica comunitaria en este punto, vid., per omnia, C. KoRTHALS, «Zusagen», en J.L. SChulte [Hrsg.], Handbuch Fusionskontrolle, München, 2005, pp. 382-412).

El TPI, aplicando el Reglamento 4064/1989, consideró que «(...) es indiferente que el compromiso propuesto pueda calificarse de compromiso de comportamiento o de compromiso estructural. Es cierto que los compromisos de carácter estructural, como la reducción de la cuota de mercado de la entidad surgida de la concentración mediante la venta de una filial, son en principio preferibles desde el punto de vista del objetivo perseguido por el Reglamento, en la medida en que impiden definitivamente, o al menos de manera duradera, que aparezca o se refuerce la posición dominante previamente identificada por la Comisión, sin requerir, por otra parte, medidas de control a medio o largo plazo. No obstante, no puede excluirse a priori que compromisos que a primera vista sean de comportamiento, como la no utilización de una marca durante un período determinado o la puesta a disposición de los terceros competidores de una parte de la capacidad de producción de la empresa surgida de la concentración, o, más genéricamente, el acceso a una infraestructura esencial en condiciones no discriminatorias, puedan también impedir que aparezca o se refuerce una posición dominante» (STPI Gencor, 25 marzo 1999, T-102/96, Rec. 1999, p. II-753, apartado 319).

140. La Comisión adoptó una Comunicación sobre soluciones aceptables con arreglo al Reglamento (CEE) n. ${ }^{\circ} 4064 / 89$ del Consejo y al Reglamento (CE) n. ${ }^{\circ}$ 447/98 de la Comisión (DO C 68 de 2 marzo 2001), en virtud de la cual, «en el asunto Gencor, el TPI sentó el principio de 
que el objetivo fundamental de los compromisos era garantizar estructuras de mercado competitivas. Por consiguiente, los compromisos consistentes en meras promesas de comportarse de determinada forma, por ejemplo, el compromiso de no abusar de una posición dominante creada o reforzada por la concentración prevista, no se considera por sí solo apropiado para hacer compatible la concentración con el mercado común (...)» (punto 9). «Una vez realizada la concentración, y pese a la posibilidad de establecer algunas garantías provisionales, las condiciones idóneas de competencia en el mercado no pueden restablecerse realmente hasta que se cumplan los compromisos. Por tanto, los compromisos deben poder ejecutarse efectivamente y en un plazo reducido. Los compromisos no deben requerir ulterior control una vez aplicados [salvo casos excepcionales]» (punto 10).

141. La Comisión, - como era previsible teniendo en cuenta lo expuesto anteriormente (K. Pieters, «Commission verus Tetra Laval: another defeat for the European Comisión», European Law Reporter, n. ${ }^{\circ} 4$, april 2005, p. 158) - entendió que no podía valorar aquellas promesas de comportamiento a los efectos de declarar viable la concentración Tetra/Sidel, además de considerar la dificultad de comprobar su cumplimiento. El Tribunal de Justicia, en cambio, de acuerdo con lo dispuesto por el TPI, afirmó que la Comisión debía haber tenido en cuenta estos compromisos (en el mismo sentido, L. Petre/A. Nucara, «Standard of proof and scope of judicial review in EC merger cases: everything clear after Tetra Laval?», Eur.Compet.L.Rev., vol. 26, n. ${ }^{\circ}$ 12, december 2005, p. 703). Quizá, a partir de la sentencia del caso Tetra/Sidel, se propongan concentraciones con promesa de no llevar a cabo determinados comportamientos (G. Drauz, «Conglomerate and vertical mergers in the light of the Tetra Judgement», Competition Policy Newsletter, n. ${ }^{\circ}$ 2, 2005, p. 39).

$$
\text { Alfonso-Luis Calvo Caravaca y Juliana Rodríguez Rodrigo }
$$

Caso N. ${ }^{\circ}$ 20. Concentraciones: STPI 21 septiembre 2005, EDP/Comisión, T-87/05

\section{NotA}

142. La Comisión Europea concluyó el 9 diciembre 2004 (Asunto COMP/M. 3440, EDP/ENI/GDP) que la proyectada operación de adquisición del control conjunto sobre la principal empresa gasística portuguesa, $G D P$, por parte de la mayor compañía eléctrica de Portugal, $E D P$, y la empresa eléctrica italiana, ENI, era susceptible, pese a los compromisos propuestos por las partes, de obstaculizar el desarrollo de la competencia efectiva en una parte sustancial del mercado común y, consecuente, debía 
ser prohibida. Decisión que fue recurrida por EDP ante el TPI y confirmada, finalmente, por éste, sin perjuicio de la anulación de determinadas conclusiones del ejecutivo comunitario.

143. La aplicabilidad de la normativa en materia de competencia en los mercados energéticos (gas, electricidad y petróleo) presenta determinadas peculiaridades, en atención fundamentalmente, a las tensiones derivadas del paulatino proceso de liberalización y apertura de estos sectores, tradicionalmente objeto de férrea regulación por los poderes públicos. De hecho, esta particularidad se pone de manifiesto en la valoración realizada por el TPI de la aplicabilidad del Reglamento sobre control de las concentraciones entre empresas en el mercado portugués del gas, sujeto, en el momento de decisión del caso a un proceso de liberalización-privatización (a). La sentencia también reviste interés desde otra perspectiva, concretamente, en atención al intento de concreción e interpretación realizado por el TPI sobre el régimen en materia de compromisos en el marco de la concentración empresarial, analizando determinadas cuestiones, tanto de carácter procedimental o formal, como referentes a la valoración sustantiva realizada por la Comisión sobre las soluciones propuestas por las partes, orientadas a eliminar los efectos anticompetitivos de la operación a fin de evitar su prohibición (b).

144. a) Liberalización del mercado gasístico portugués: Directiva 2003/55/CE: En el seno de la Comunidad Europea se está llevando a cabo un proceso de progresiva apertura de los mercados de la energía: eléctricos y gasísticos. En el marco de este proceso, se encuadran, en este último sector, dos Directivas del Parlamento Europeo y del Consejo sobre normas comunes para el mercado interior del gas natural [Directiva 98/30/CE (First Gas Directive) derogada por la Directiva 2003/55/CE (Second Gas Directive]. Esta última norma está orientada a la creación de un mercado interior del gas plenamente operativo, informado por el principio de competencia leal (considerando 30). Para ello, uno de los ejes del proceso de liberalización consiste en la fijación de un calendario riguroso para la progresiva apertura del mercado. No obstante, en la propia Directiva se establece la sujeción a un calendario especial de los Estados miembros que reúnan los requisitos para ser considerados «mercado emergente» (artículo 28). Este precepto permite exencionar al Estado implicado de la aplicación de los principales preceptos de la Directiva tendentes a asegurar la apertura de los mercados del gas y el desarrollo de una competencia efectiva en los mismos. Consecuentemente, en virtud de esta derogación, los mercados gasísticos concernidos no se considerarán abiertos a la competencia hasta que el Estado haya efectivamente concretado esa apertura. Situación ésta aplicable a la República portuguesa en el momento en que la concentración entre $E D P$ y $G D P$ es objeto de examen por parte de la 
Comisión Europea, quien decide, no obstante, su prohibición, entre otras razones, porque puede facilitar el refuerzo de la posición dominante en los distintos mercados gasísticos de GDP, con la consiguiente obstaculización de la competencia efectiva en los mismos. El TPI rechaza la valoración llevada a cabo por el ejecutivo comunitario, en cuanto realizada sin tener en cuenta la trascendencia de la derogación contenida en la Directiva 2003/55/CE respecto de la aplicabilidad del artículo 2.3 del Reglamento sobre control de las concentraciones en los mercados cubiertos por la exención. Concretamente, el hecho de que los mercados del gas en Portugal - al amparo de la exención - no estuvieran abiertos a la competencia, impide la satisfacción de los dos requisitos necesarios para prohibir una concentración: creación o refuerzo de una posición dominante y obstaculización significativa de la competencia. En el primer caso, debido a que la situación de GDP en los mercados gasísticos era de monopolio, manifestación extrema de posición dominante, que excluye lógicamente la posibilidad de su refuerzo. Por lo que al segundo requisito se refiere, éste carece de sentido en un mercado no competitivo. Las empresas no pueden ser acusadas de restringir significativamente la competencia, cuando ésta no existe como consecuencia del marco normativo, nacional y comunitario, aplicable a los mercados afectados. Es conveniente resaltar que la apreciación de error de derecho en una parte de la decisión de la Comisión (en este caso, en lo referente a los mercados del gas) no determina la anulación de su totalidad si el análisis realizado en otros mercados relevantes (eléctricos) permite sostener la incompatibilidad de la operación con el mercado común (STPI 22 octubre 2002, Schneider Electric v. Comisión), conclusión confirmada por el TPI en el caso objeto de examen.

145. b) Valoración de los compromisos o remedios en el marco del control de las concentraciones: Cuando una concentración plantee problemas de competencia por poder llevar a la creación o fortalecimiento de una posición dominante, las partes pueden intentar modificar la operación inicialmente proyectada, a fin de despejar las dudas sobre sus eventuales efectos lesivos de la competencia y, de este modo, obtener la decisión de compatibilidad de la operación (artículos 6 y 8 del Reglamento 4064/89; artículos 6 y 8 del Reglamento 139/2004, actualmente vigente). La Comisión Europea ha intentado clarificar su política en relación con los compromisos de modificación de operaciones de concentración, mediante la publicación de una Comunicación en la materia (Comunicación sobre las soluciones aceptables con arreglo al Reglamento (CEE) $n .^{\circ} 4064 / 89$ del Consejo y al Reglamento (CE) n. ${ }^{\circ} 447 / 98$ de la Comisión, 2001/C68/03). Comunicación que, no obstante, no despeja todos los posibles problemas que plantea la implementación práctica y valoración de las soluciones o 
remedios frente a concentraciones prima facie anticompetitivas. Por ello, resulta especialmente útil el papel interpretativo desempeñado por las autoridades judiciales. En este sentido, en la sentencia objeto de examen, el TPI concreta determinados aspectos importantes respecto de la política en materia de compromisos, tanto en su vertiente formal o procedimental como en lo relativo a los criterios sustantivos de valoración de los mismos. De entre ellos, merecen especial atención los referentes al reparto y alcance de la carga de la prueba (a') y a los criterios de valoración de la propuesta modificada de concentración (b').

146. (a') Si una concentración empresarial no crea o refuerza una posición dominante anticompetitiva, la Comisión deberá necesariamente autorizarla (artículo 2 Reglamento 4064/89). Por tanto, en ella recae la carga de demostrar la incompatibilidad de una operación con el mercado común, con independencia de que ésta sea la inicialmente proyectada o de que haya sido objeto de modificaciones ulteriores por las empresas afectadas (artículo 8.2 Reglamento 4064/89). Es, por tanto, a la Comisión a quien compete probar que los compromisos presentados por las partes no eliminan los riesgos competitivos derivados de la concentración. Es más, el hecho de que el párrafo 6 de la Comunicación en materia de soluciones establezca que: «es responsabilidad de las partes demostrar que las soluciones propuestas, una vez aplicadas, eliminan la creación o el fortalecimiento de la posición dominante determinada por la Comisión (...)», no puede conducir a una alteración de este reparto legal de la carga de la prueba. Incluso asumiendo que el ejecutivo comunitario pretende, con esta afirmación, responsabilizar a las partes, de la prueba de la efectividad de las soluciones propuestas, no cabe deducir del mismo que, en caso de duda, la operación deba ser prohibida. Antes al contrario, en último extremo, es la Comisión la que debe demostrar que la concentración modificada, debe ser declarada incompatible con el mercado común ya que conduce a la creación o refuerzo de una posición dominante, de la que se deriva una obstaculización significativa de la competencia efectiva.

147. (b') La Comisión Europea está obligada a llevar a cabo una valoración global de la concentración tal y como ésta resulta una vez introducidas las correspondientes modificaciones por las partes. En principio, debe examinar, por tanto, cada uno de los compromisos presentados en relación con los problemas competitivos identificados en cualquiera de los mercados afectados. No obstante, ello no impide una valoración individualizada de las diversas soluciones en relación exclusivamente a un mercado o problema competitivo específico, si el resto de propuestas carecen de relevancia o de suficiente significación económica en ese contexto. La rapidez que informa el procedimiento previsto en el Reglamento, convierte en irrealista 
la posibilidad de reiniciar íntegramente el análisis de la operación, como si la transacción proyectada hubiera sido notificada ab initio en la forma resultante de la introducción de las modificaciones.

Carmen Herrero Suárez 